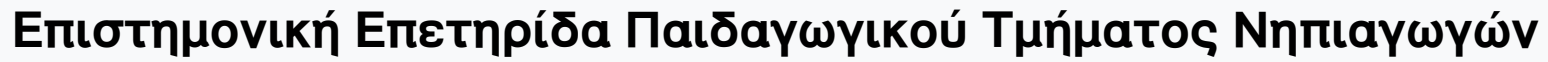

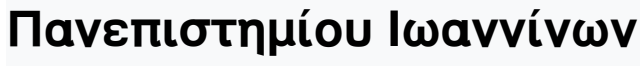

Tóp. 5 (2012)

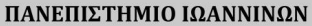

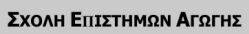

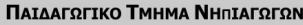

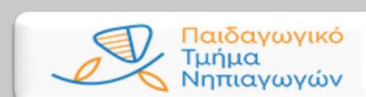

Nnriaywywiv

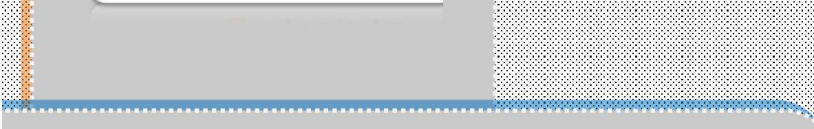

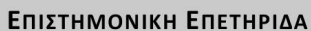

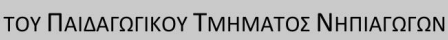

JOURNAL OF RESEARCH IN EDUCATION AND TRAINING

DEPARTMENT OF EARLY CHILDHOOD EDUCATION

томог 5-VoL5

2012

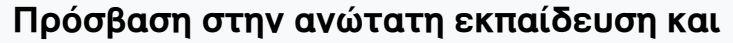

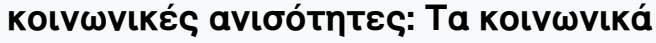

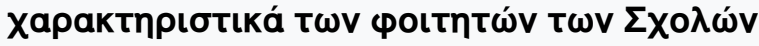

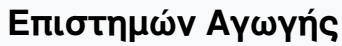

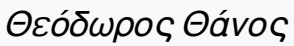

doi: $\underline{10.12681 / j r e t .8675}$

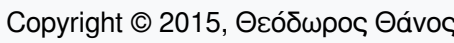

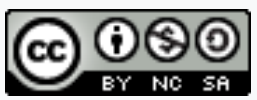

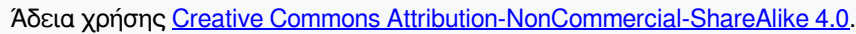

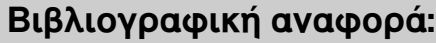

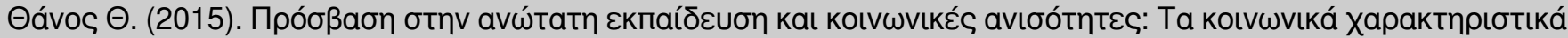

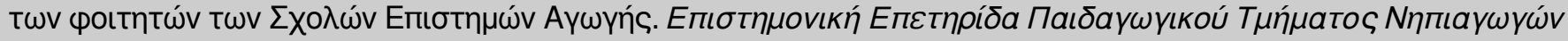

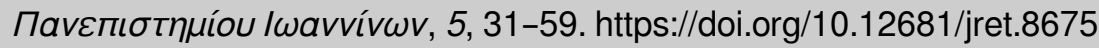




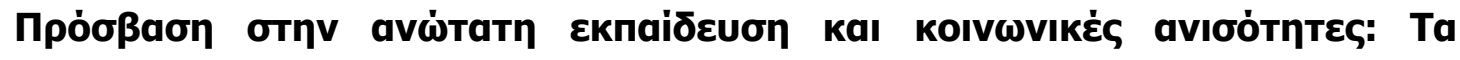

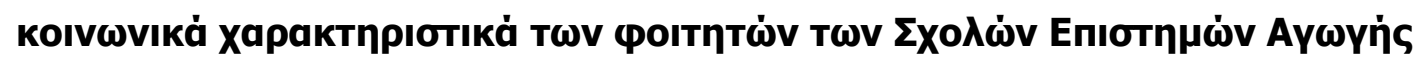

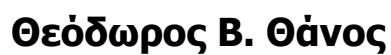

\section{ПЕРІАНЧН}

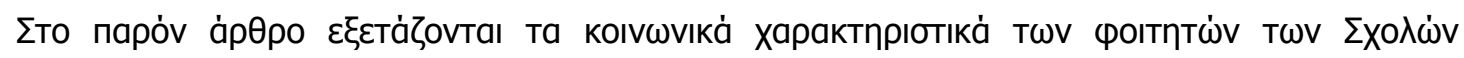

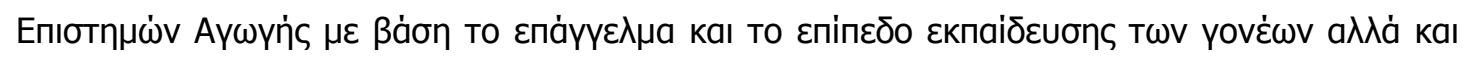

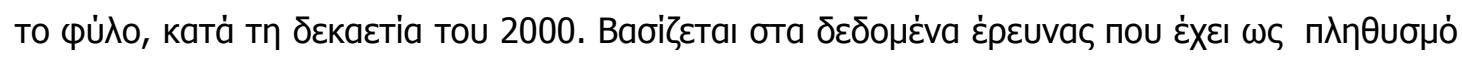

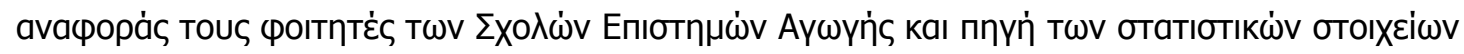

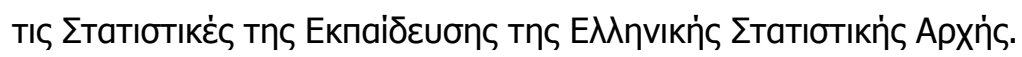

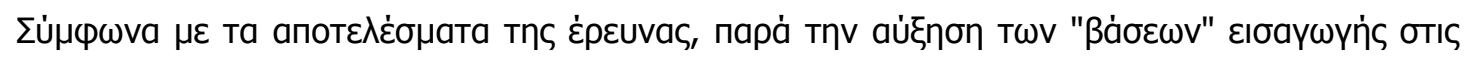

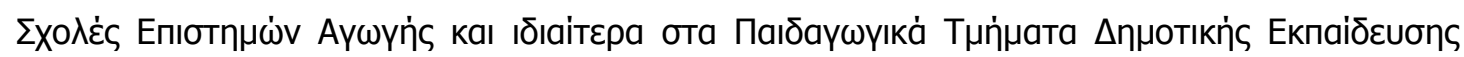

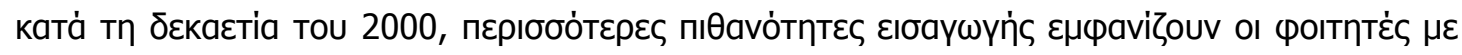

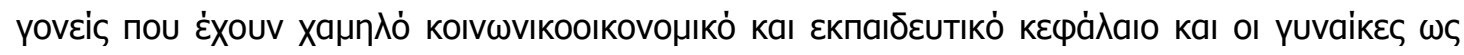

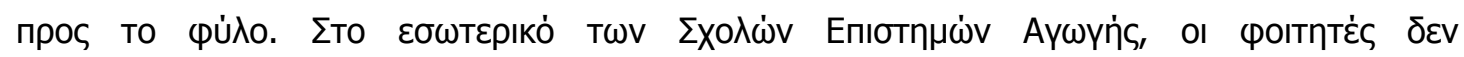

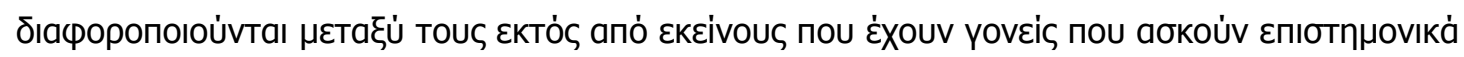

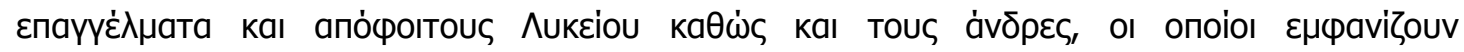

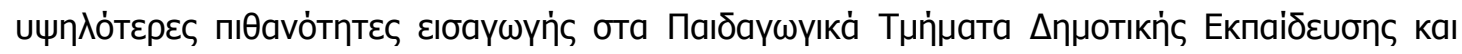

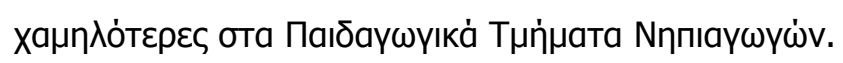

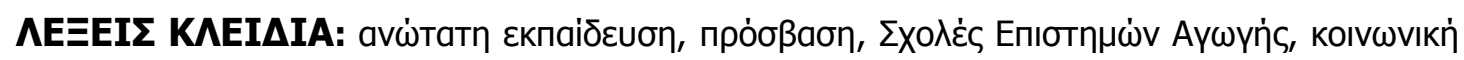

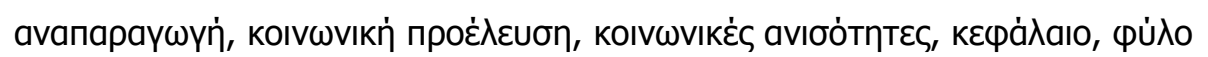




\title{
Access to higher education and social inequalities: The social characteristics of the students in the Schools of Education Sciences
}

\section{Theodoros B. Thanos}

\begin{abstract}
This article examines the social characteristics of students in the Schools of Education Sciences on the basis of parental occupation and education level as well as gender during the first decade of the $21^{\text {st }}$ century. It is based on the data of a research the population of which is students who study in the Schools of Education Sciences, while the data come from official education statistics of the Hellenic Statistical Authority.

According to the research, despite the increase in the performance necessary in the University entrance examinations as far as the Schools of Education Sciences are concerned, and in particular the Departments of Primary School Education during the first decade of the $21^{\text {st }}$ century, there are more opportunities for participation in higher education for students with parents with low socioeconomic and educational capital and women as far as gender is concerned. As regards the Schools of Education Sciences there is no differentiation among students, apart from those with parents with scientific occupations and upper secondary education graduates, as well as men, who are more likely to enroll in the Departments of Primary School Education and less likely to enroll in the Departments of Pre-School Education.
\end{abstract}

KEY WORDS: higher education, access, Schools of Education Sciences, social reproduction, social background, social inequality, capital, gender 


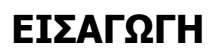

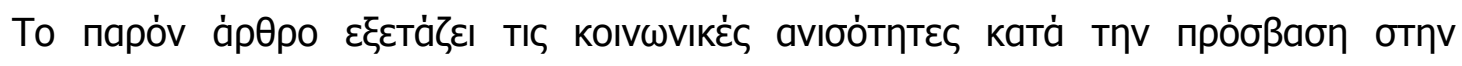

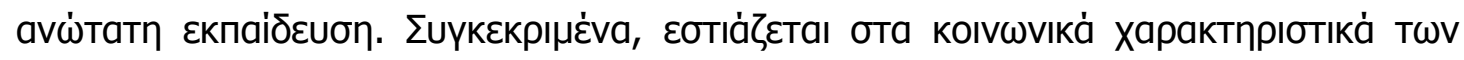

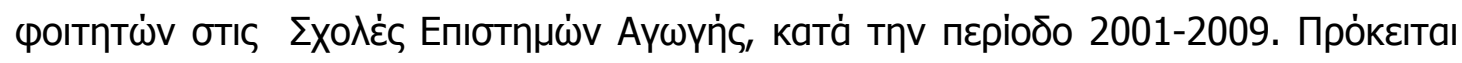

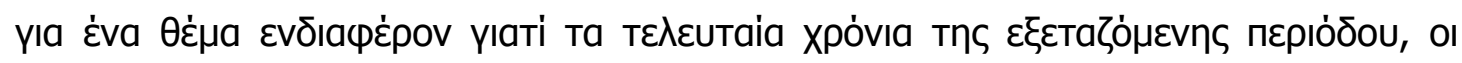

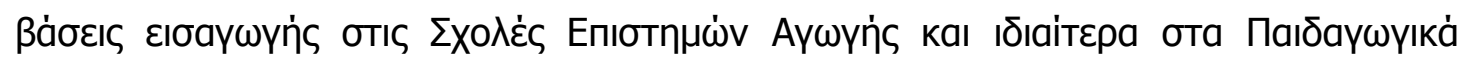

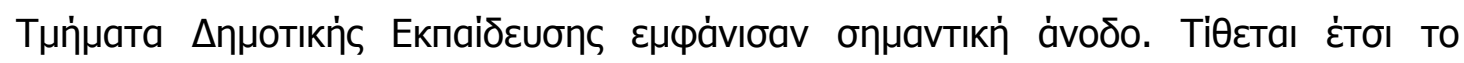

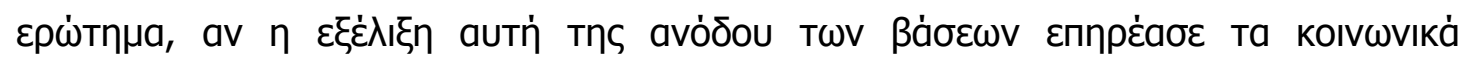

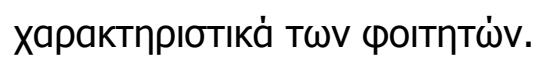

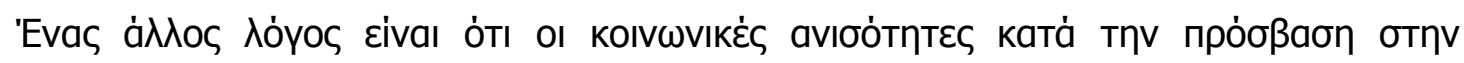

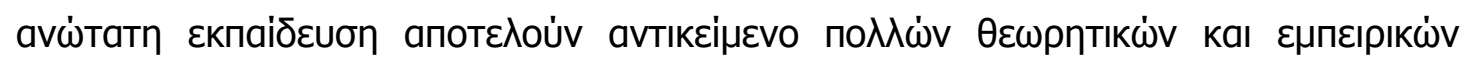

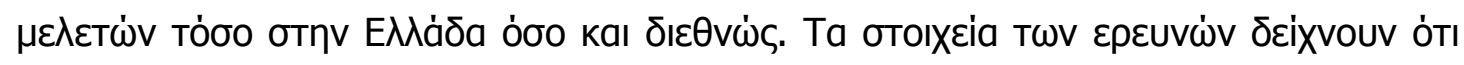

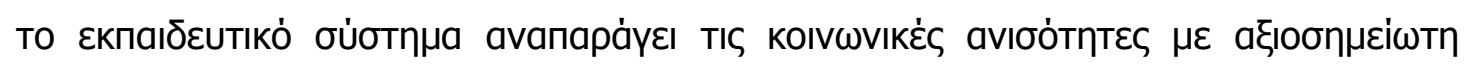

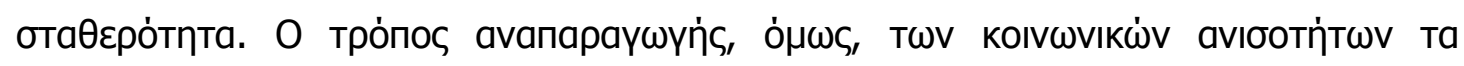

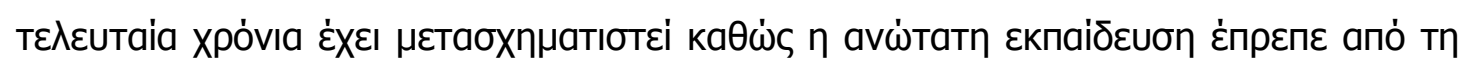

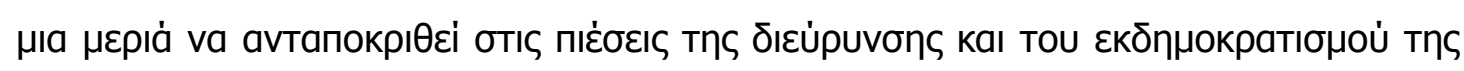

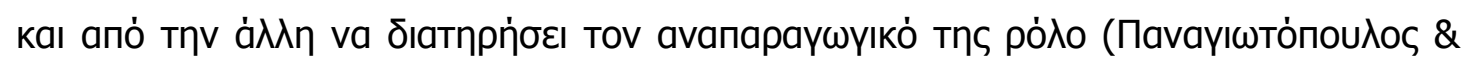

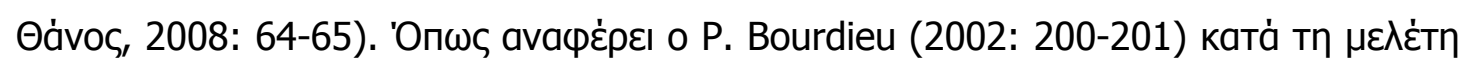

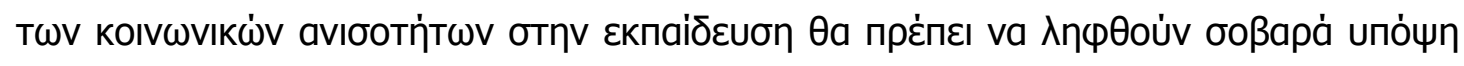

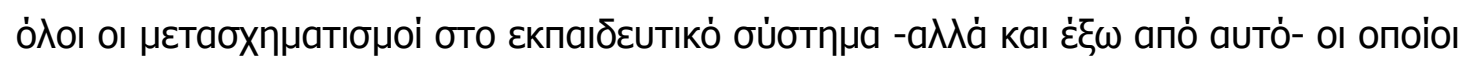

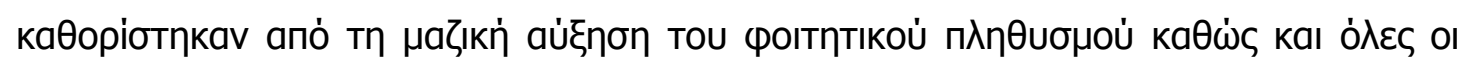

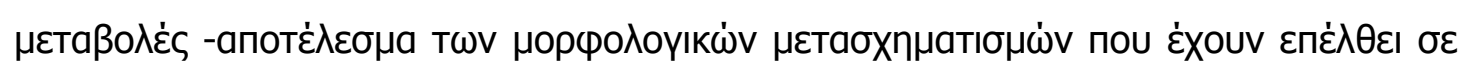

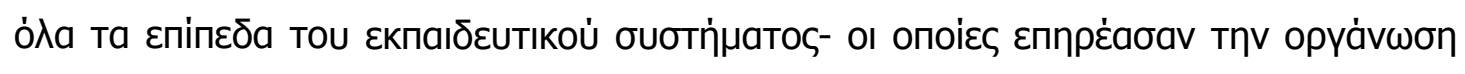

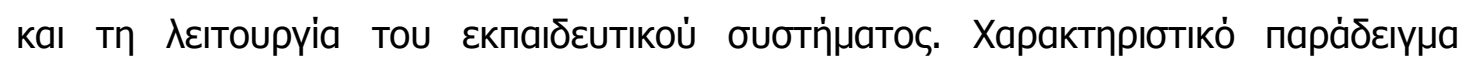

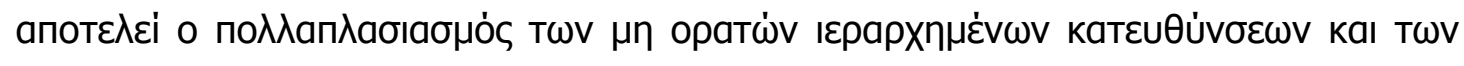

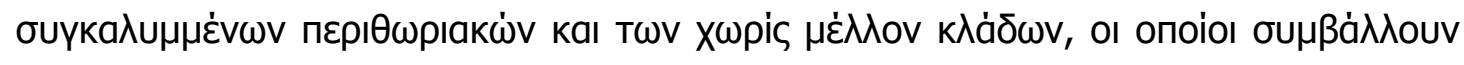

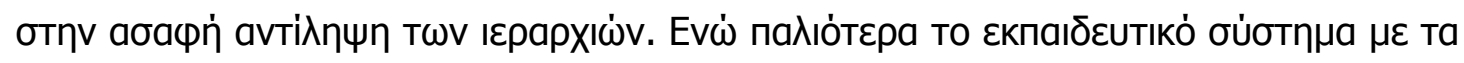

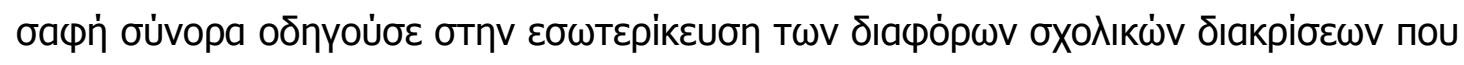

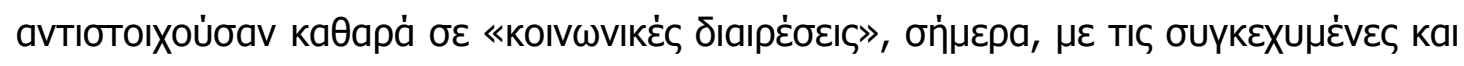

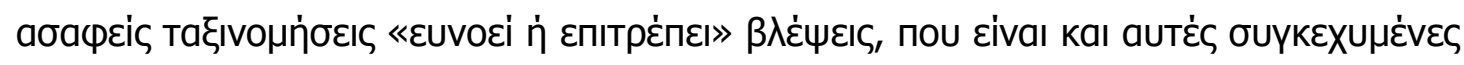

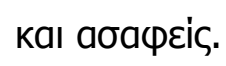

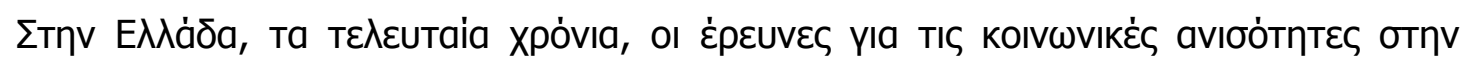

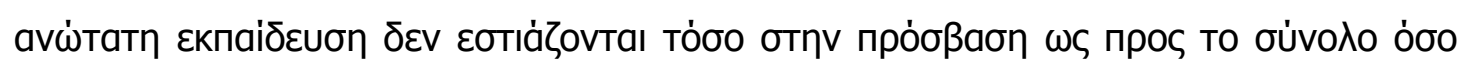




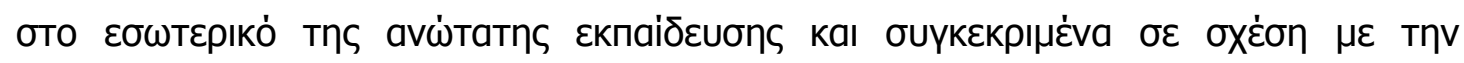

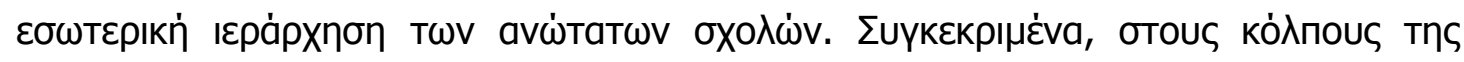

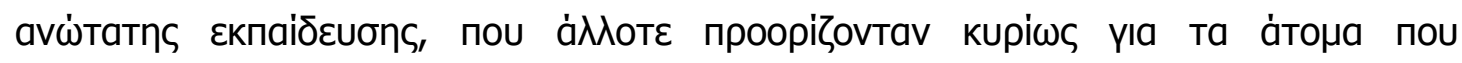

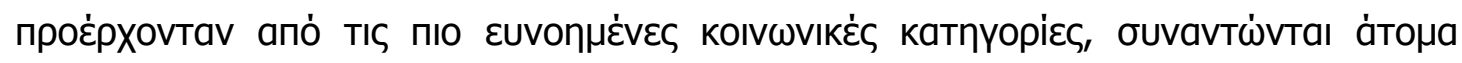

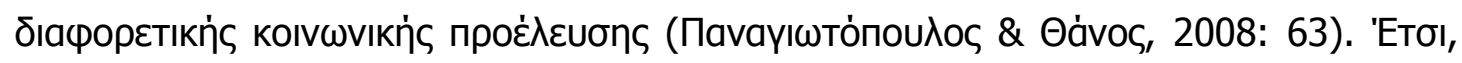

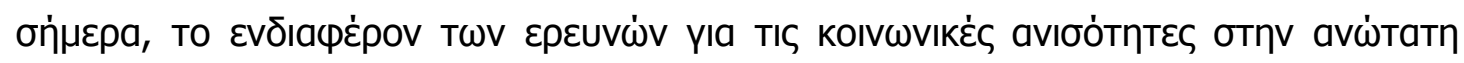

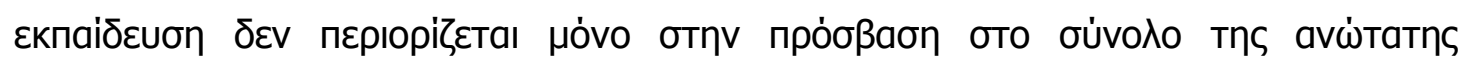

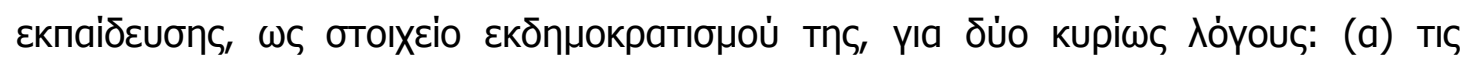

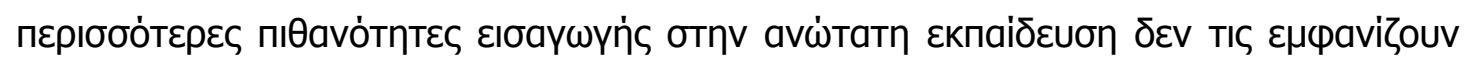

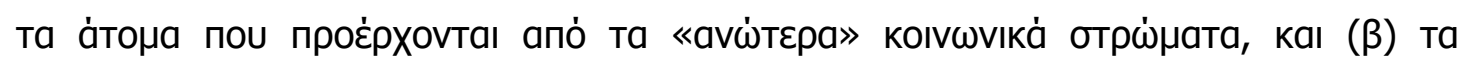

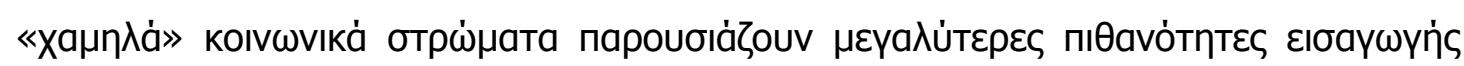

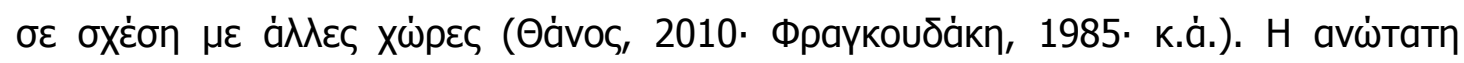

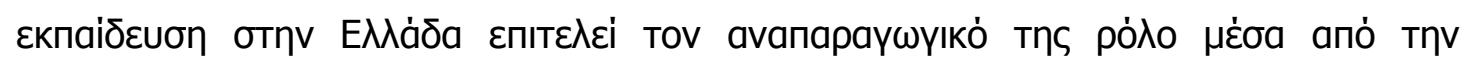

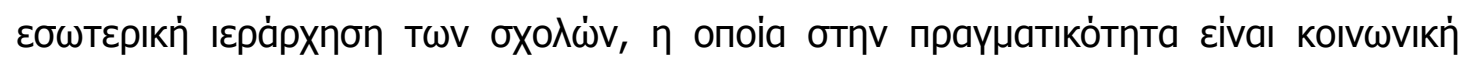

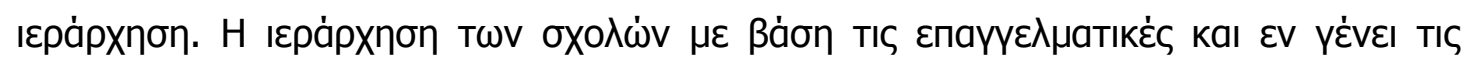

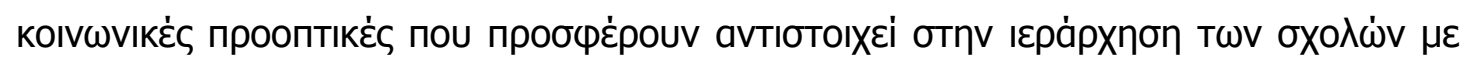

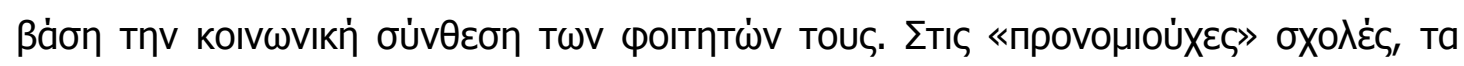

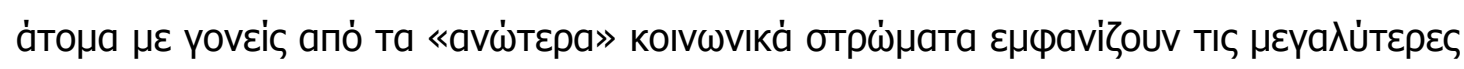

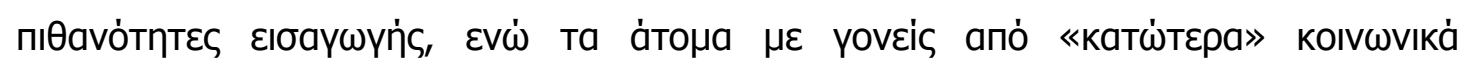

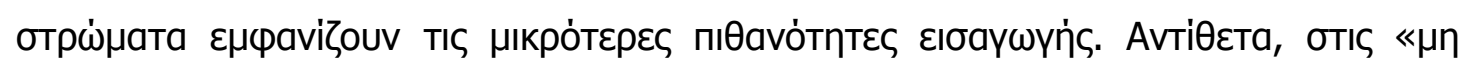

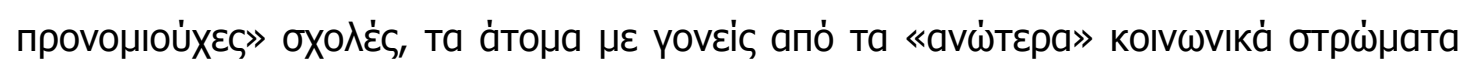

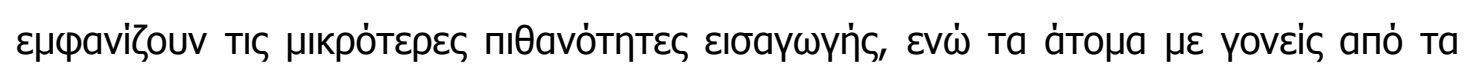

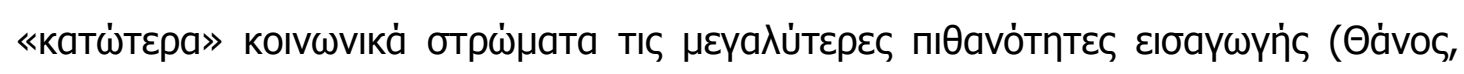

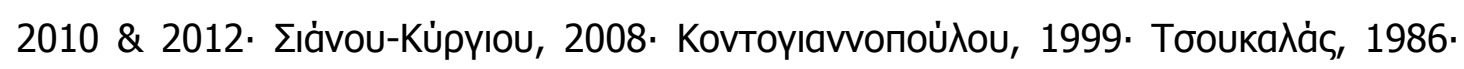
Фраүкочба́kn, 1985· к.à.).

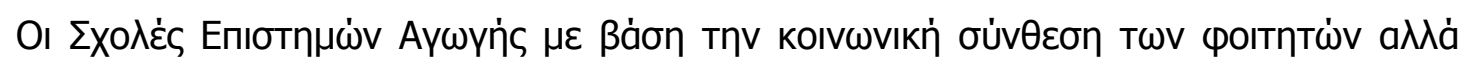

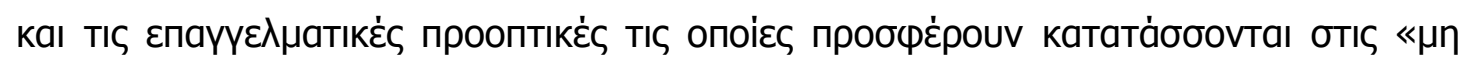

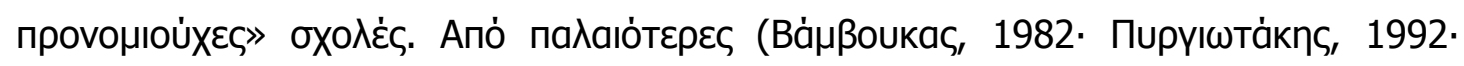

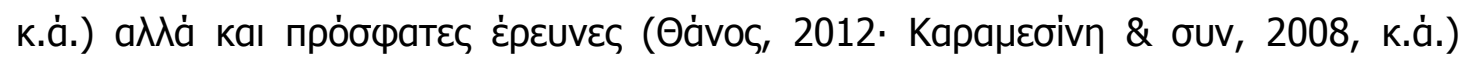

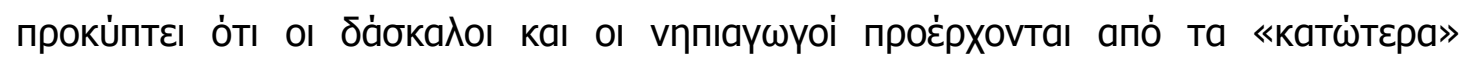

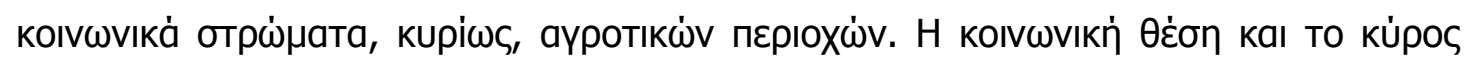

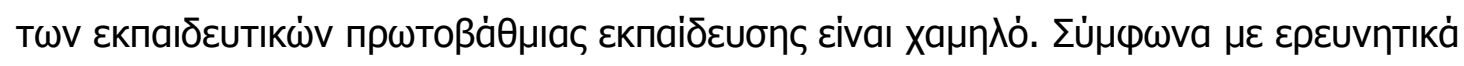

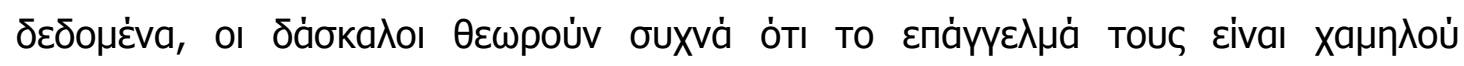

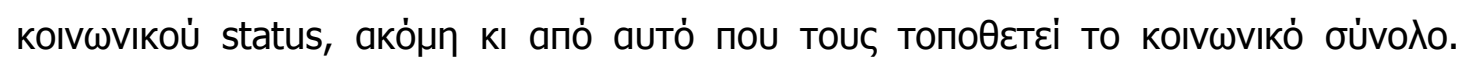




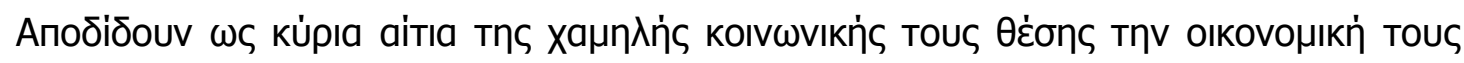

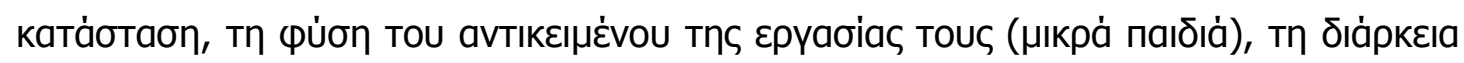

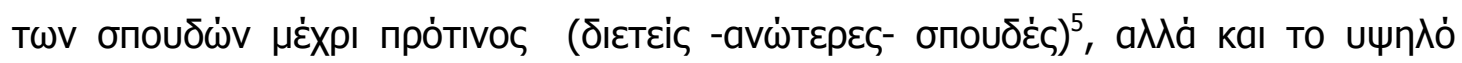

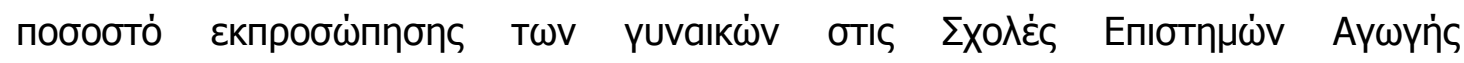

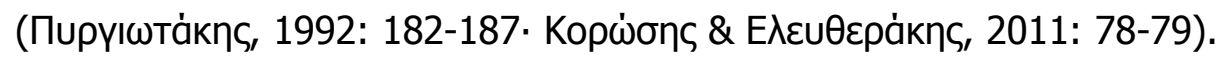

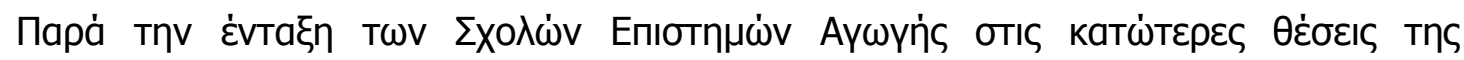

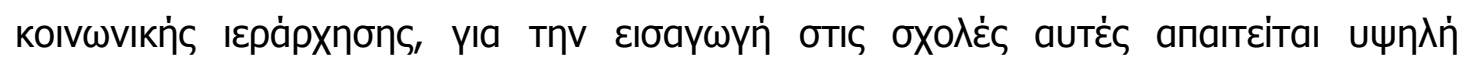

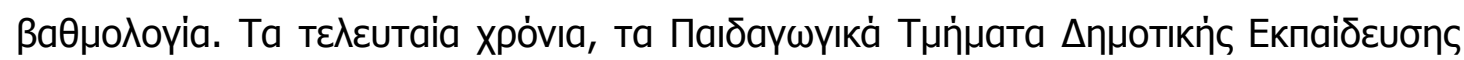

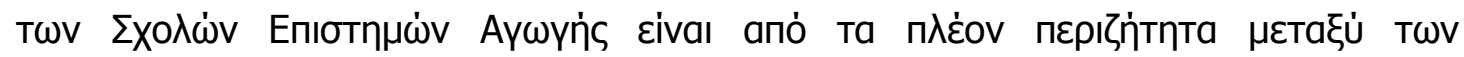

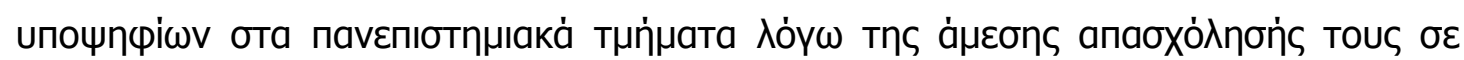

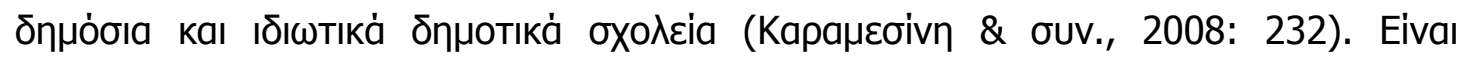

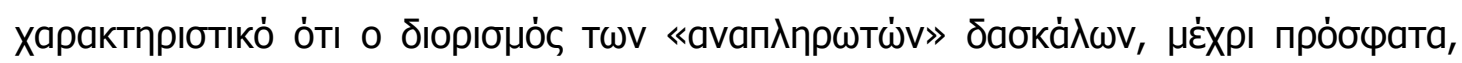

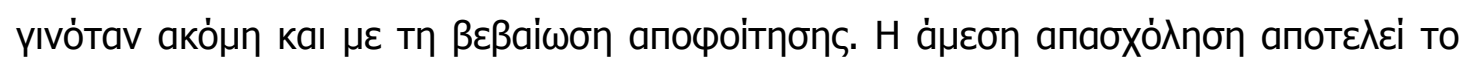

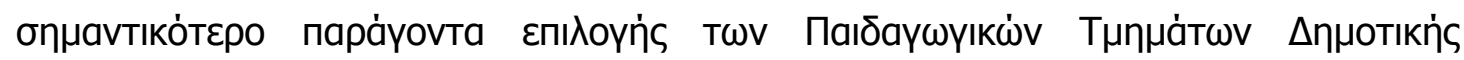

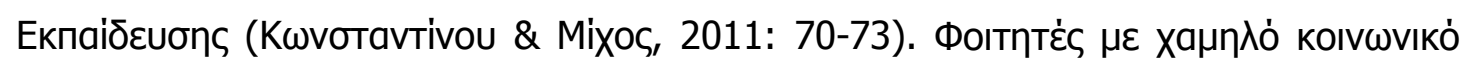

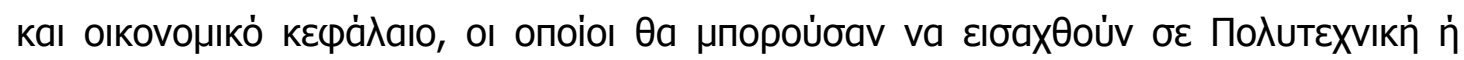

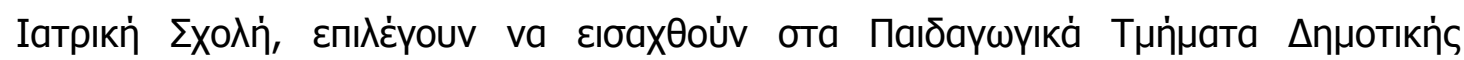

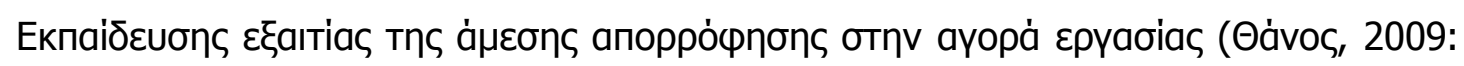

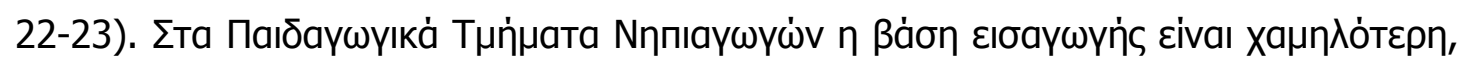

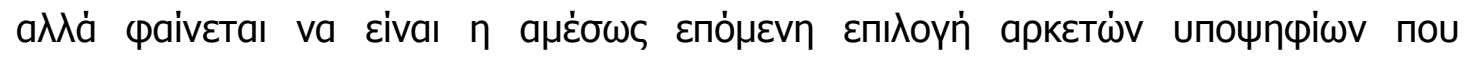

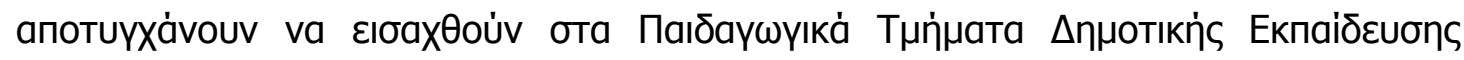

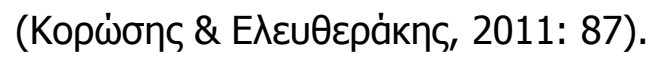

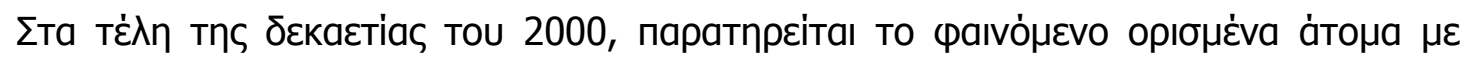

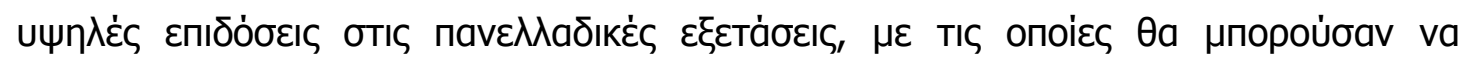

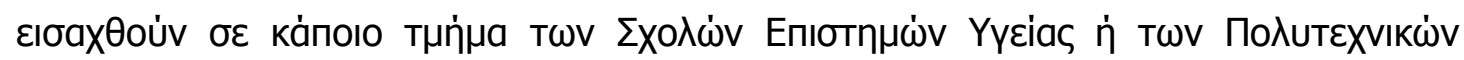

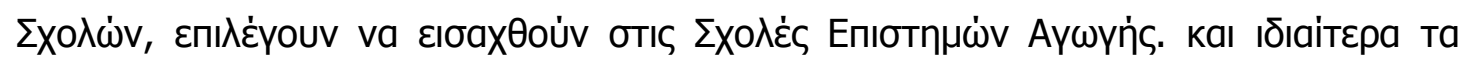

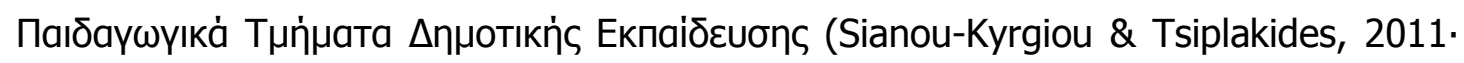

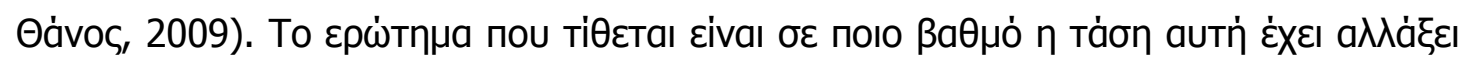

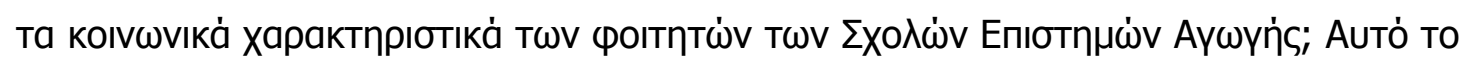

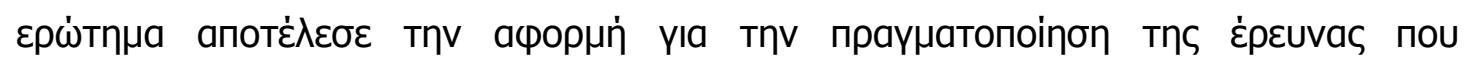

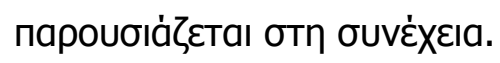

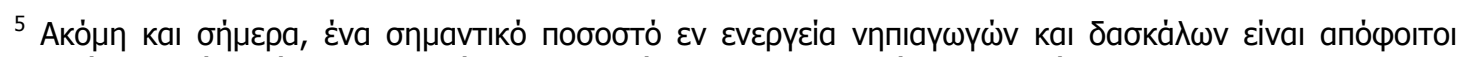

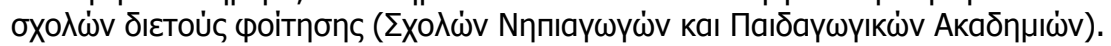




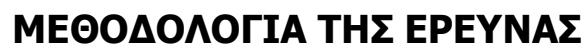

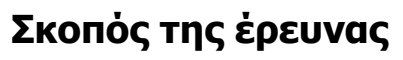

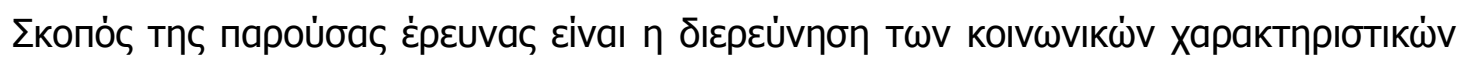

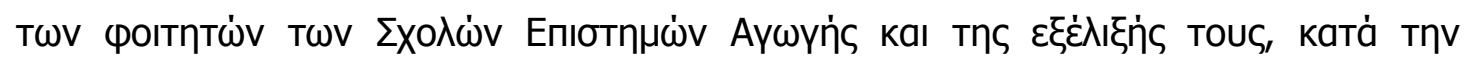

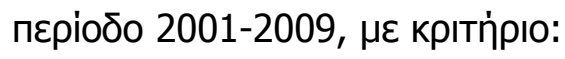

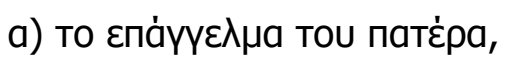

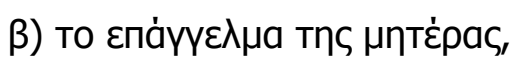

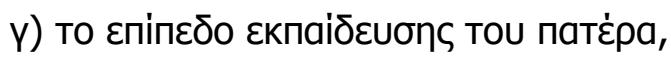

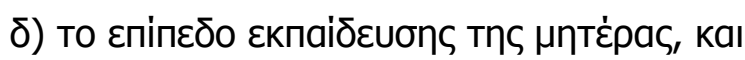

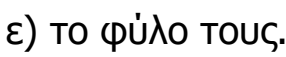

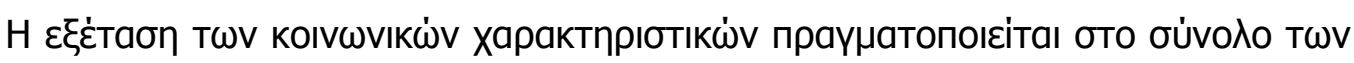

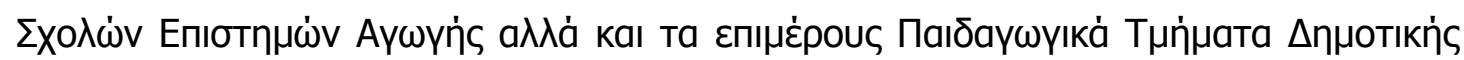

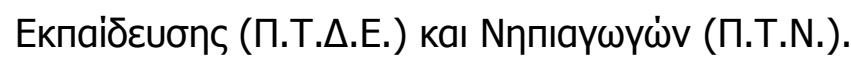

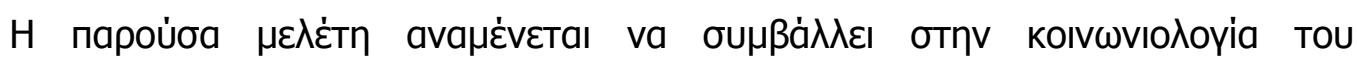

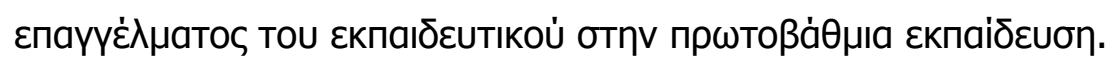

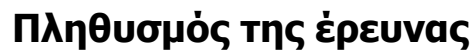

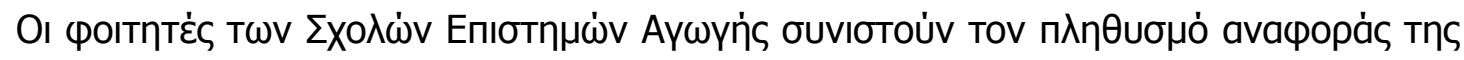

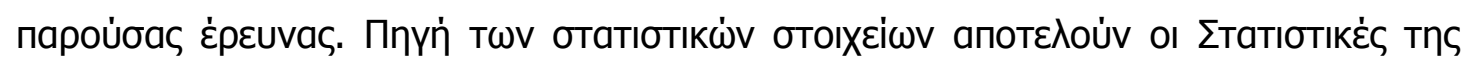

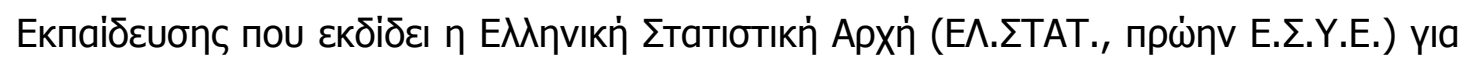

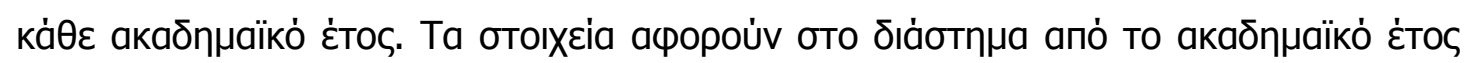

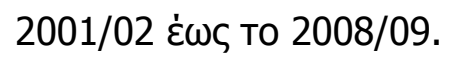

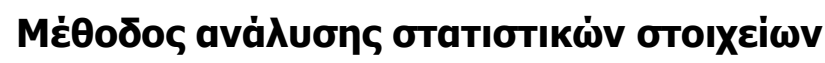

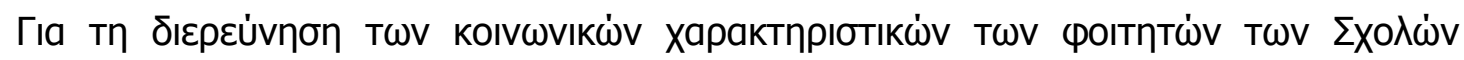

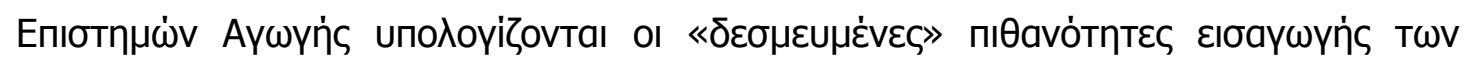

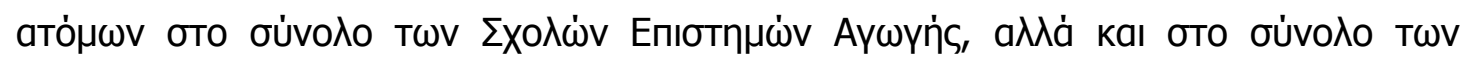

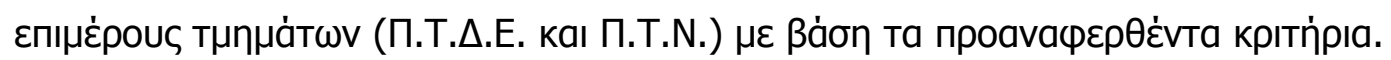

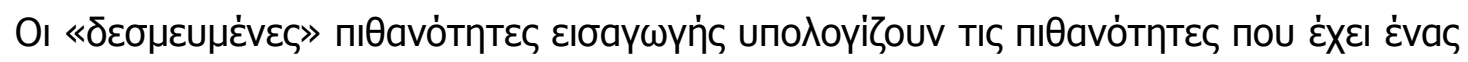

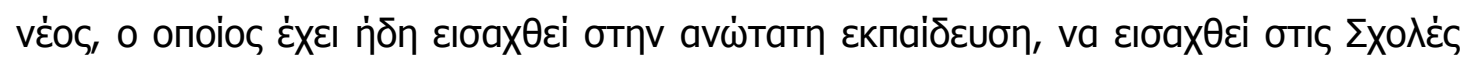

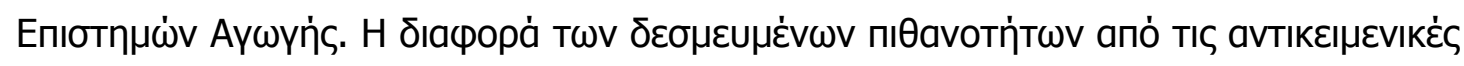

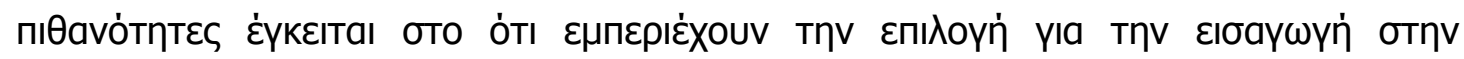

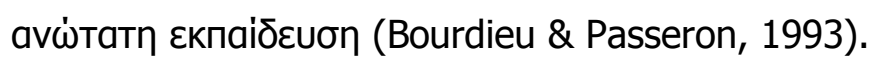




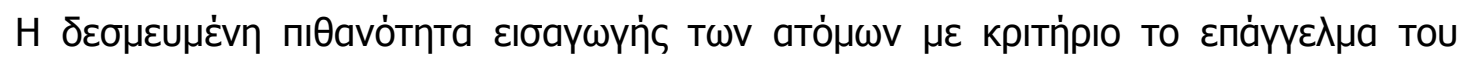

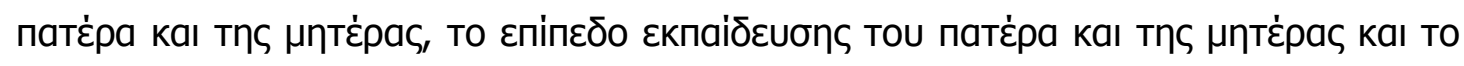

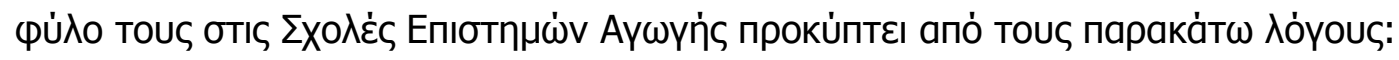

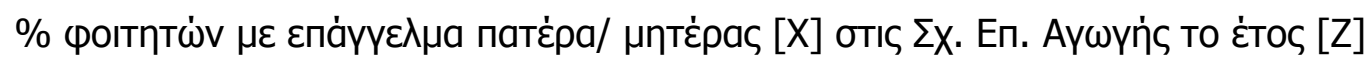

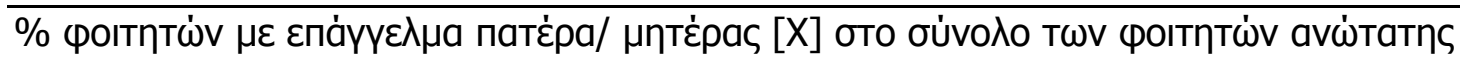

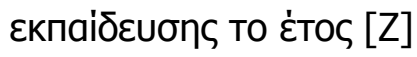

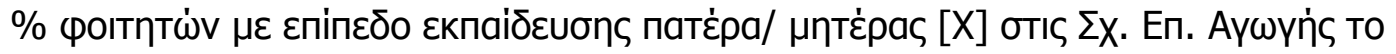
غंто५ [Z]

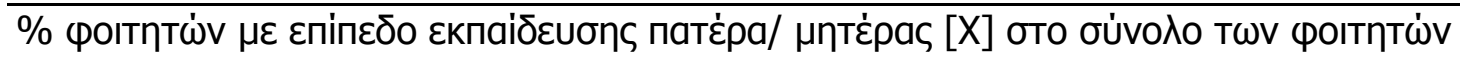

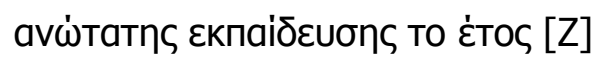

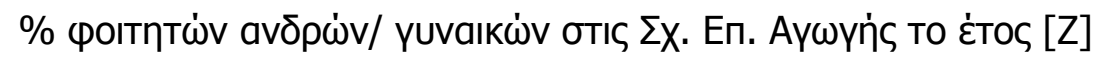

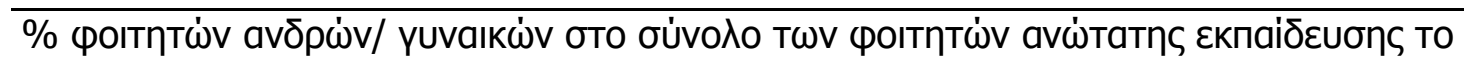
ह่тоร [Z]

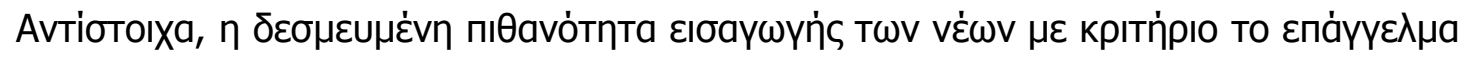

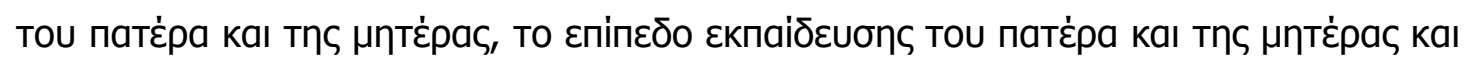

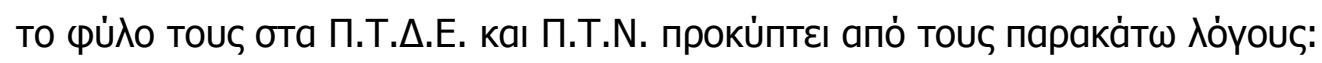

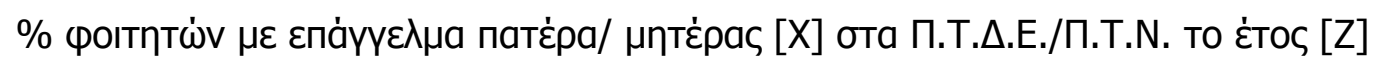

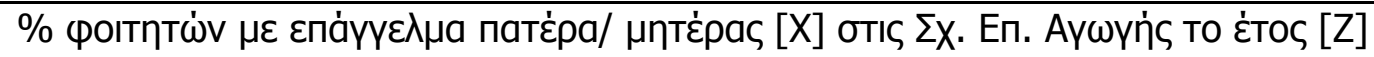

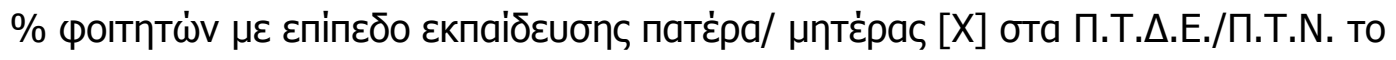
ह่тоৎ [Z]

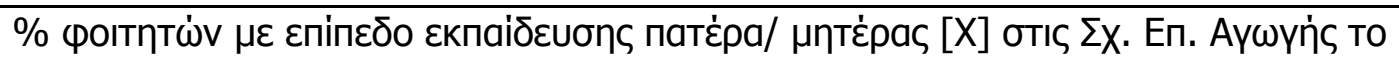
غंтоৎ [Z]

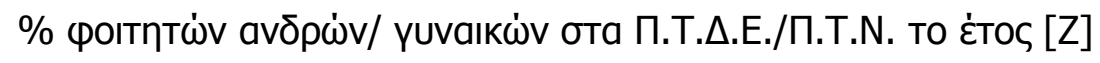

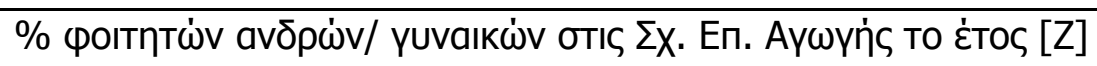

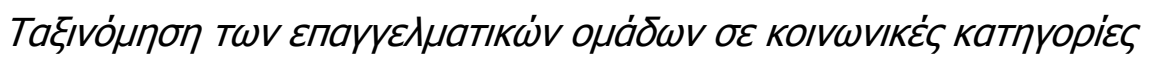




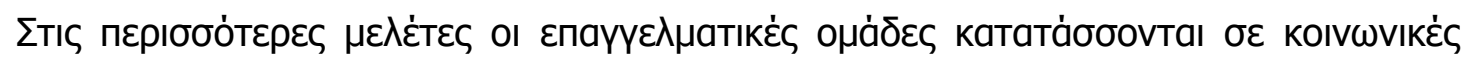

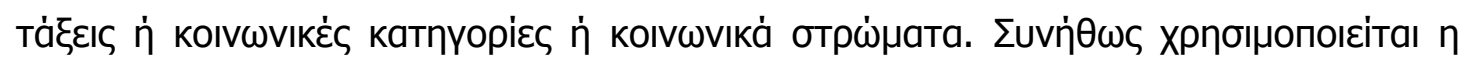

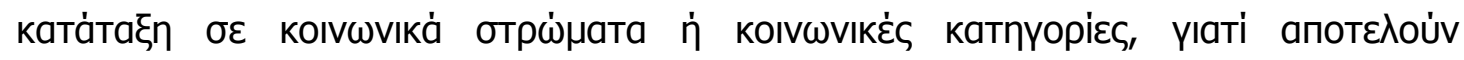

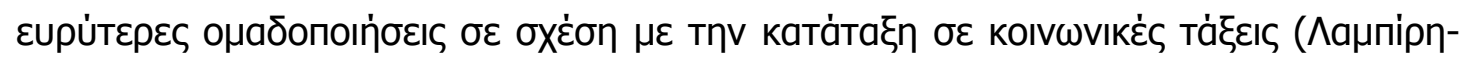
$\triangle$ Айкп, 1974: 90).

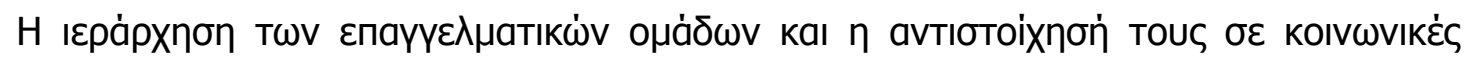

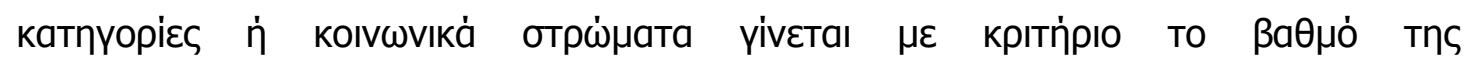

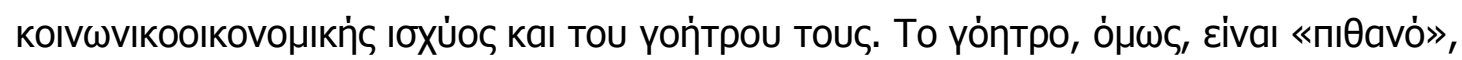

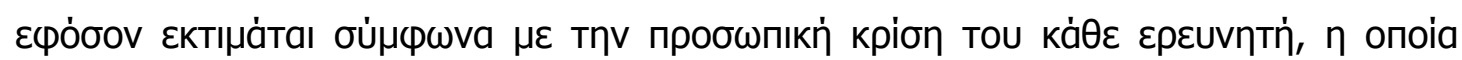

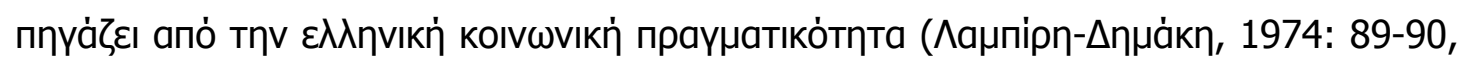
122).

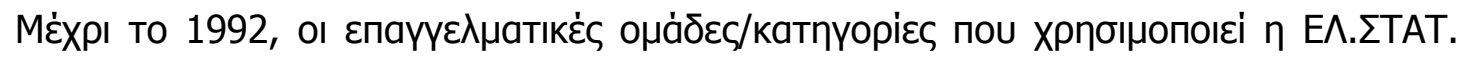

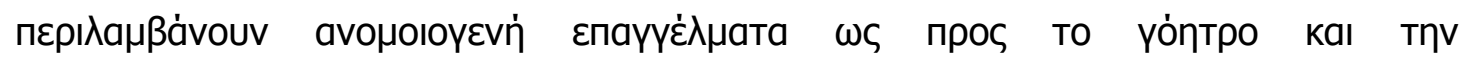

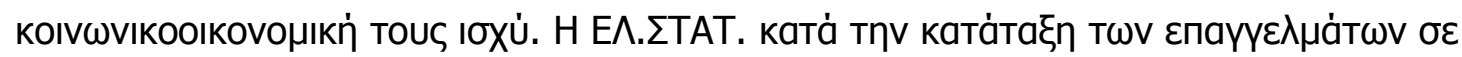

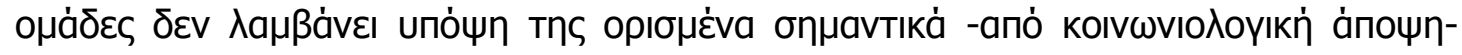

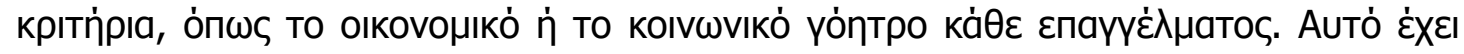

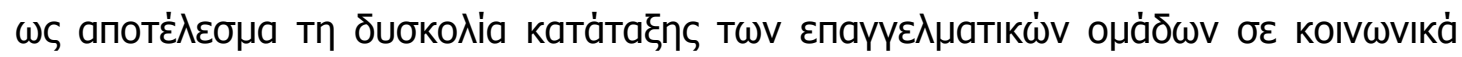

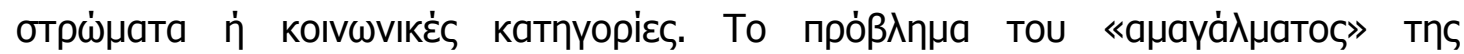

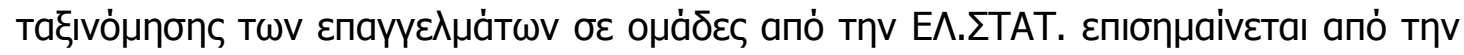

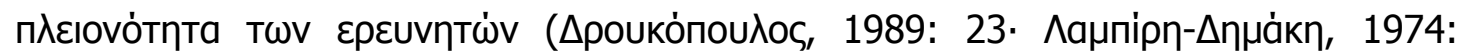

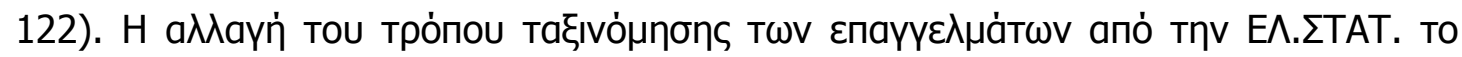

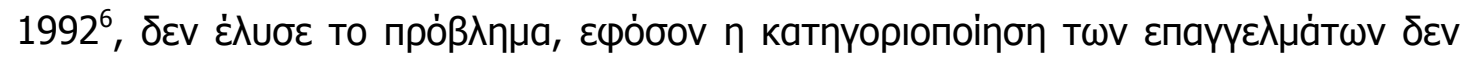

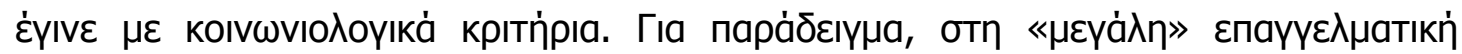

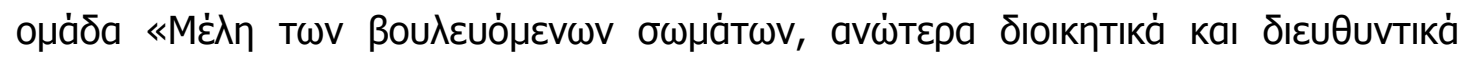

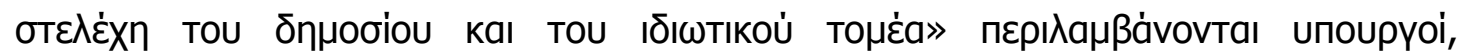

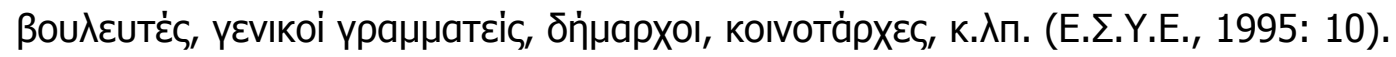

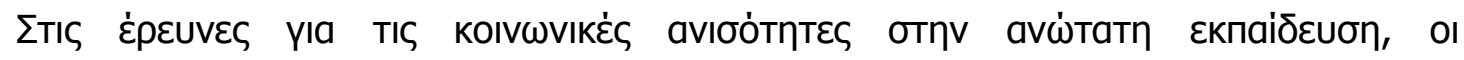

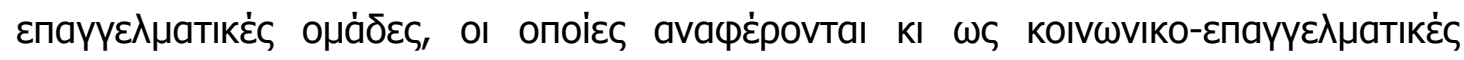

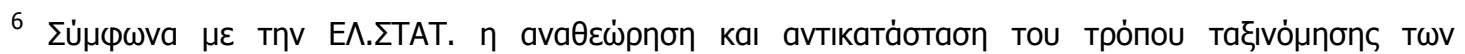

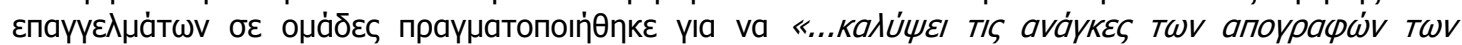

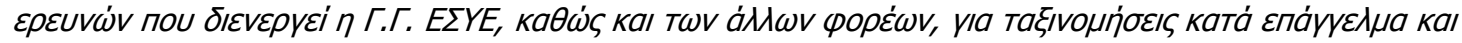

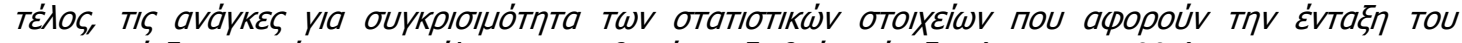

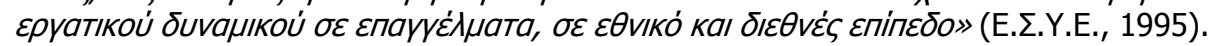




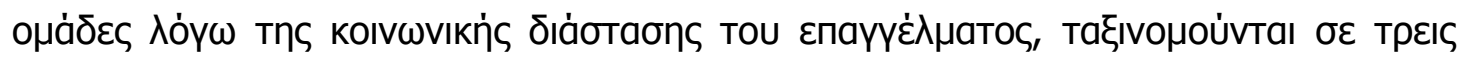

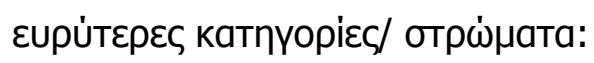

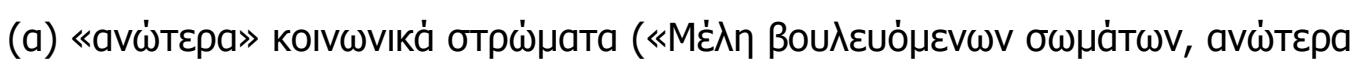

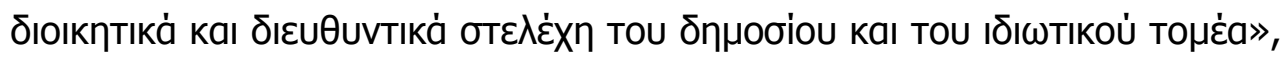

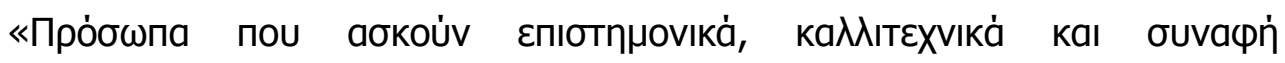

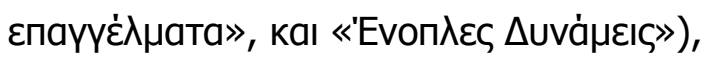

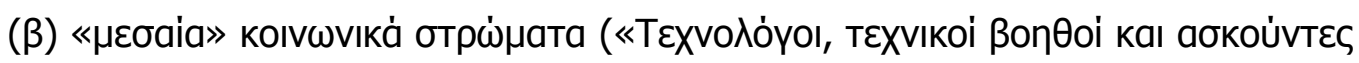

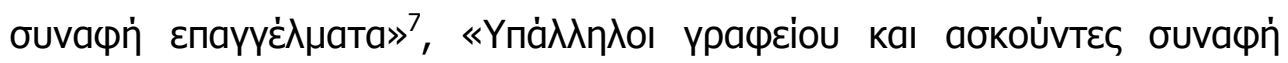

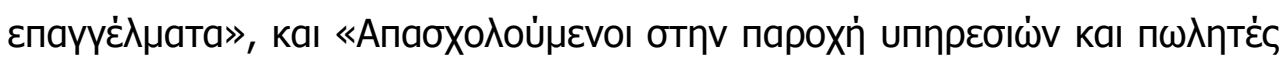

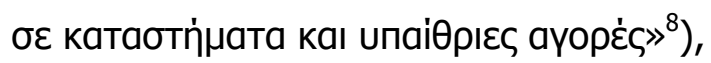

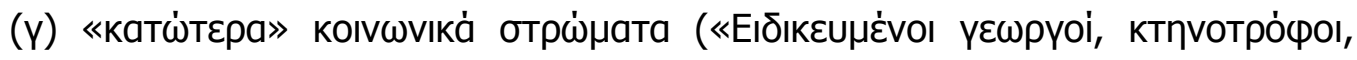

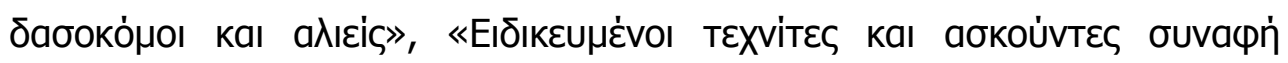

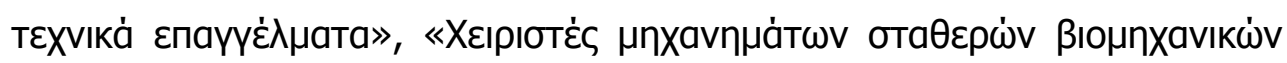

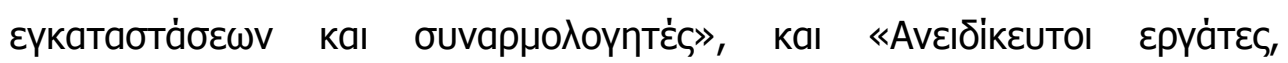

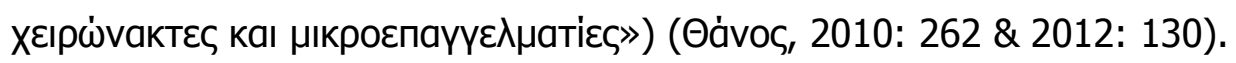

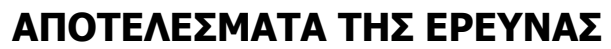

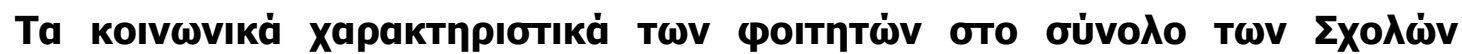

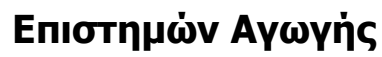

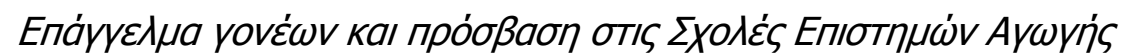

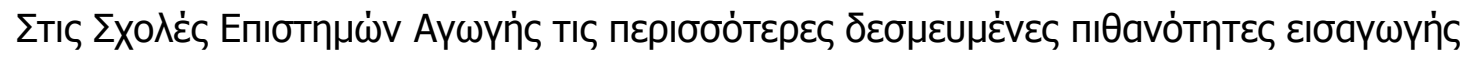

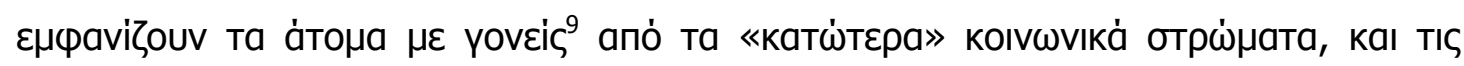

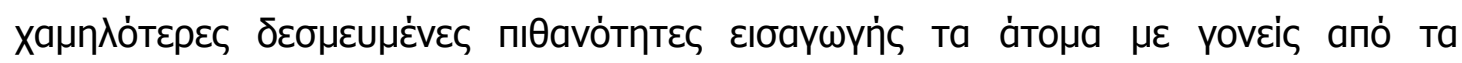

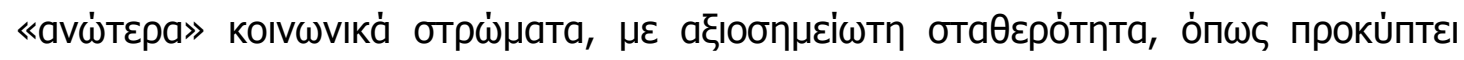

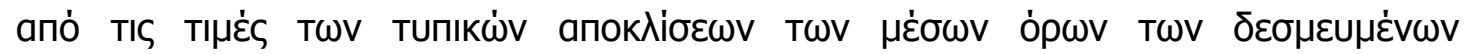

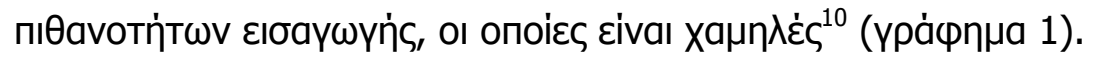

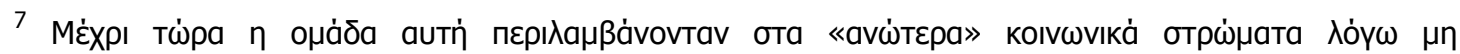

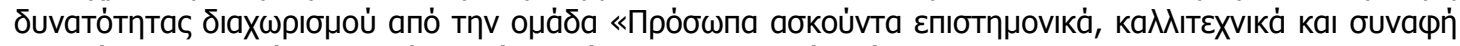

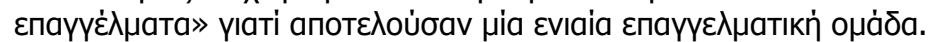

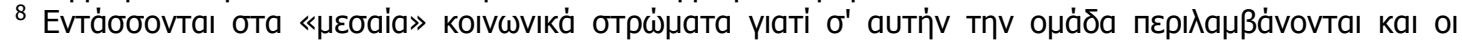

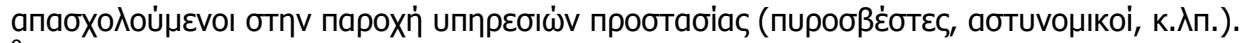

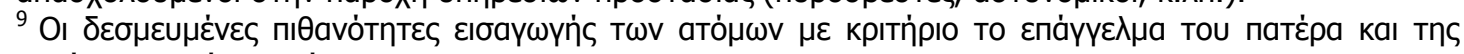

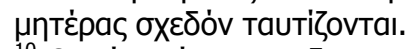

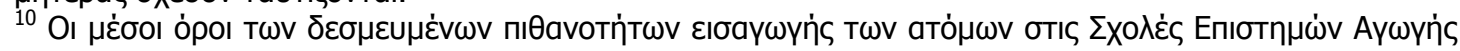

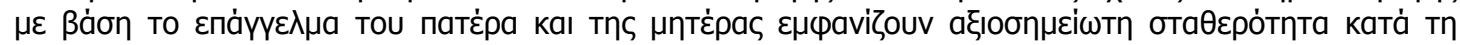

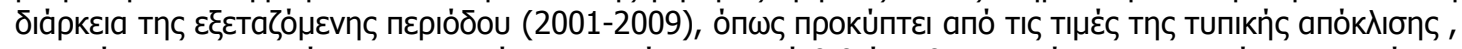

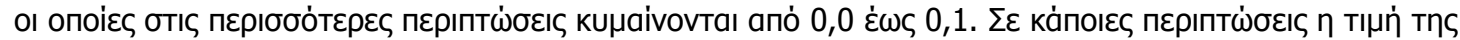

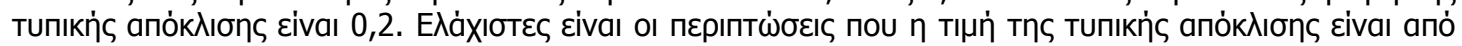




\section{Гра́фпна 1}

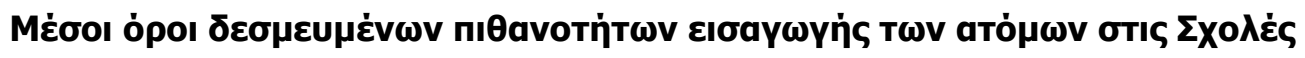

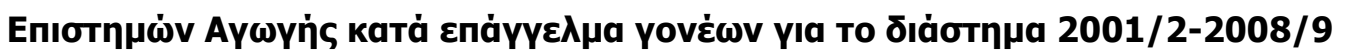

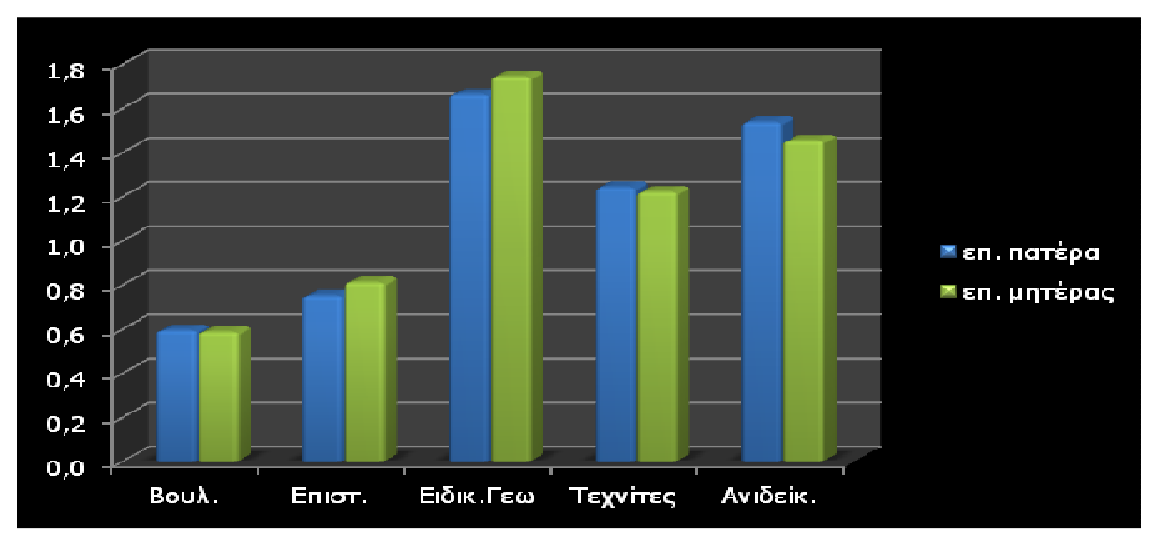

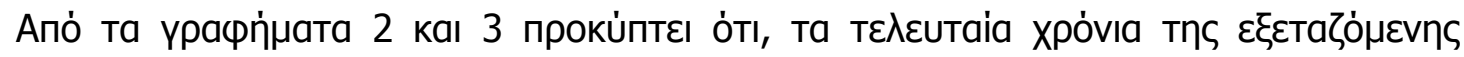

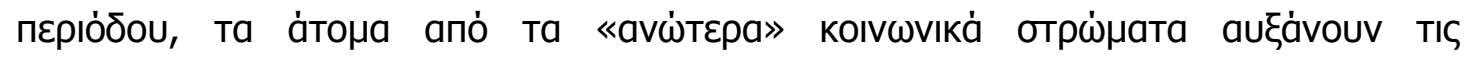

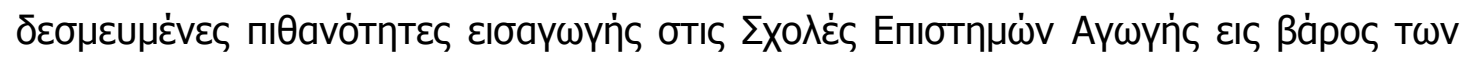

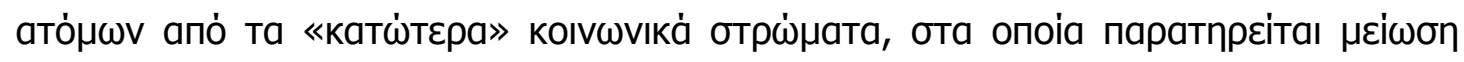

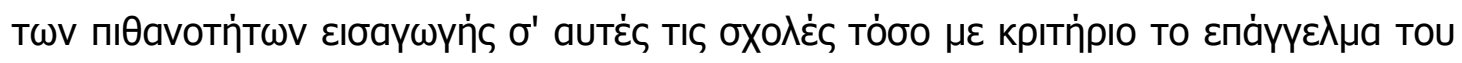

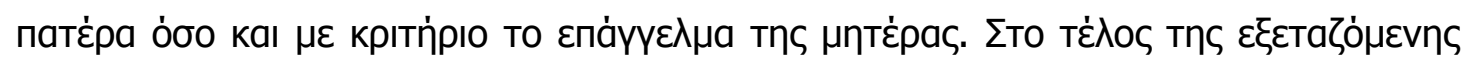

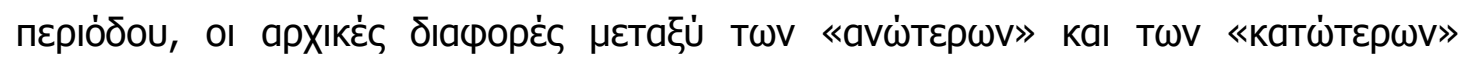

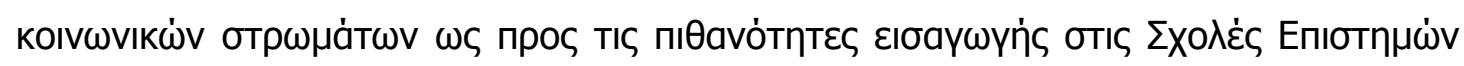

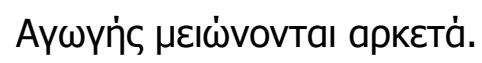

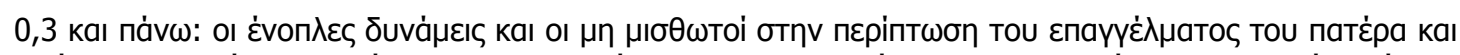

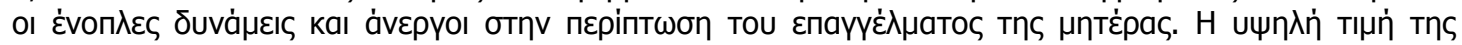

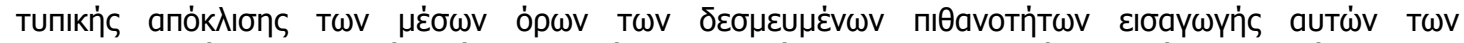

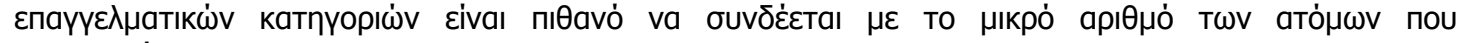

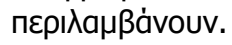




\section{Гра́фпна 2}

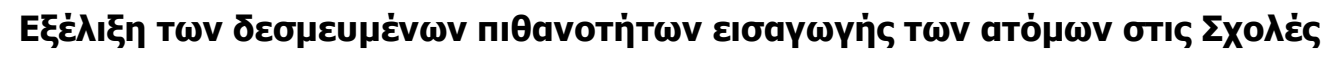

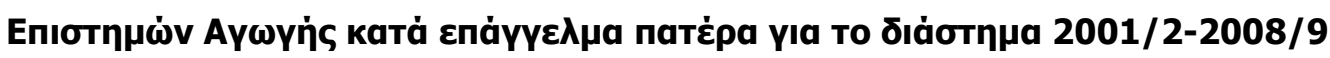

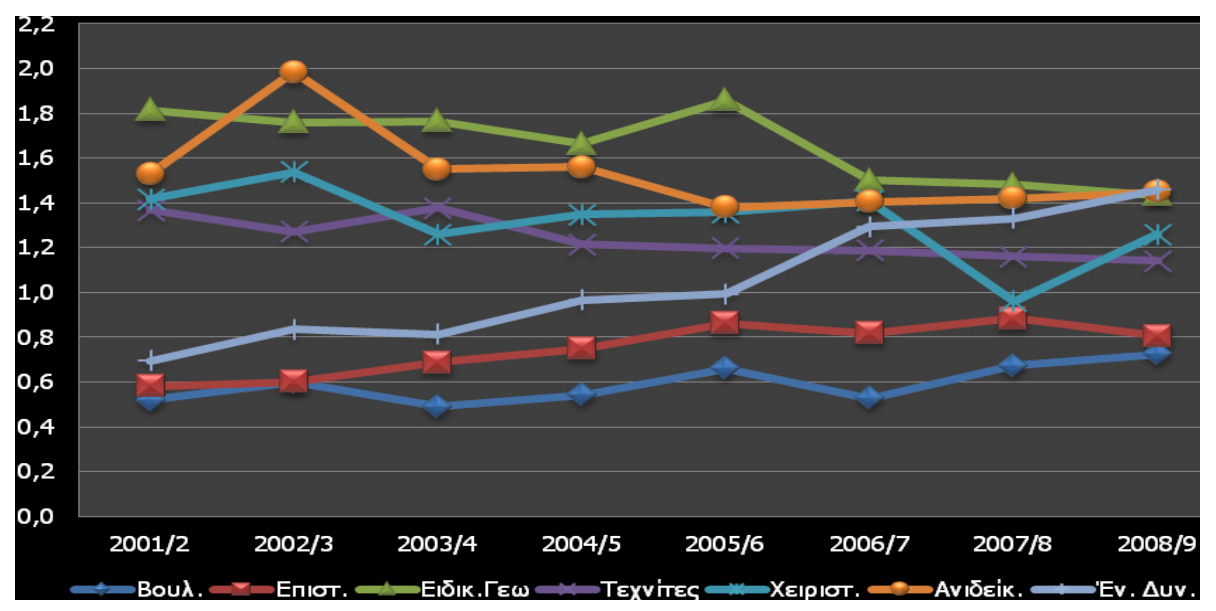

Гра́фпна 3

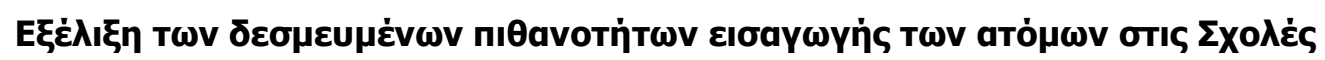

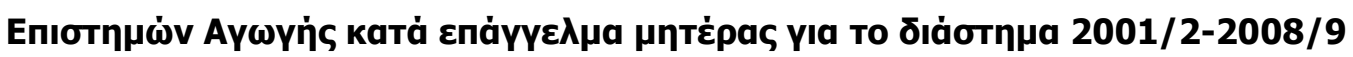

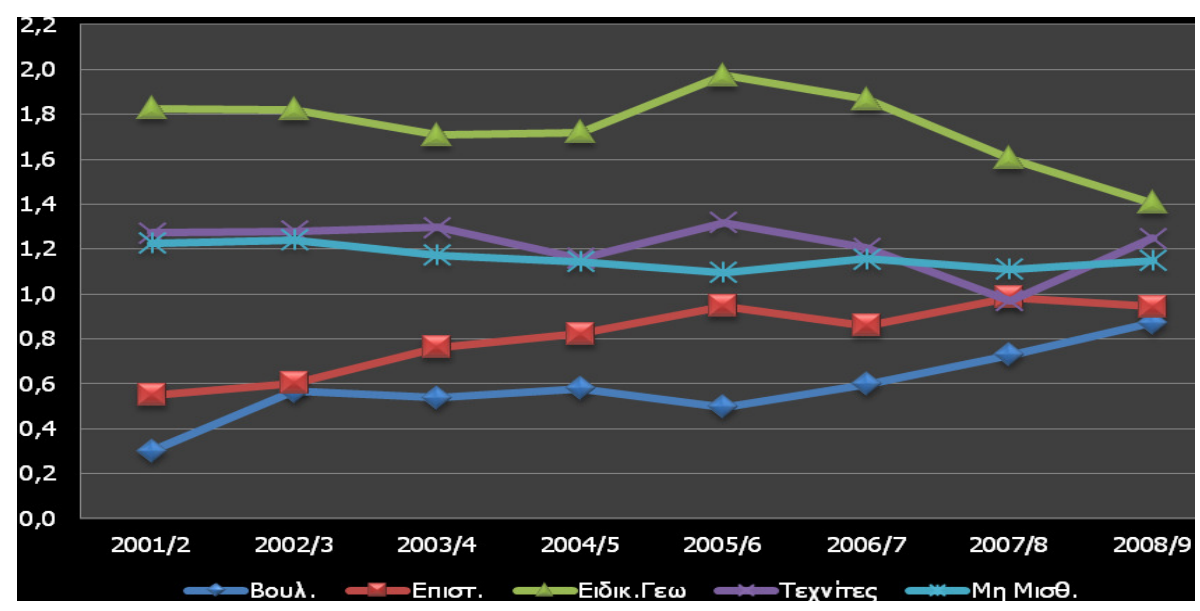

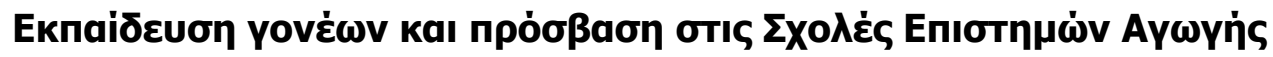

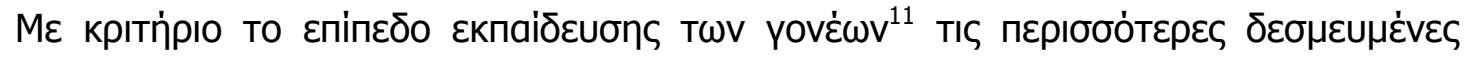

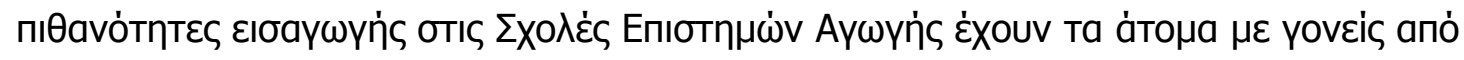

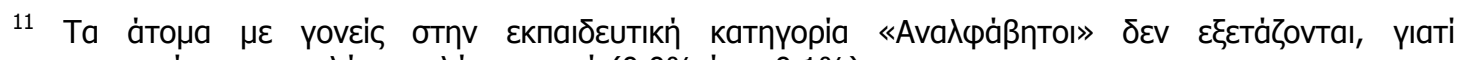

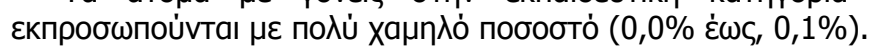




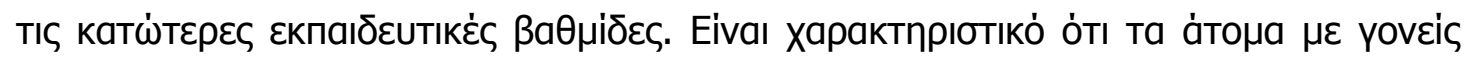

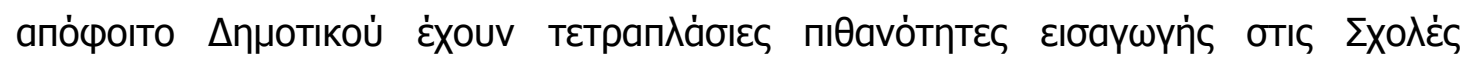

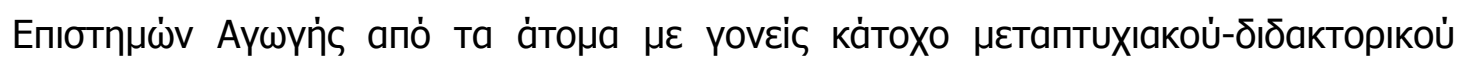

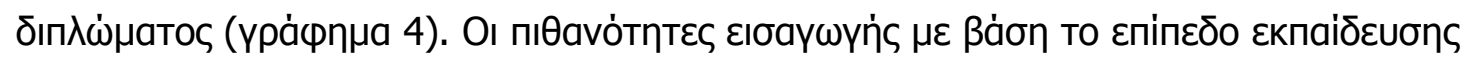

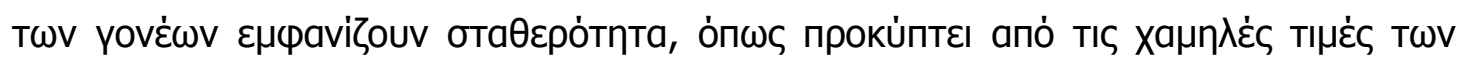

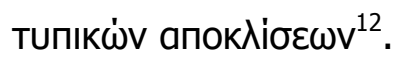

\section{Гра்фпна 4}

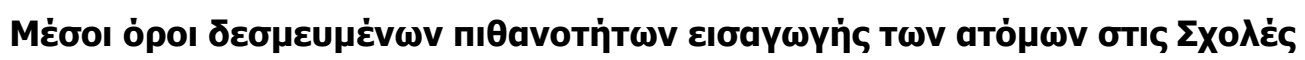

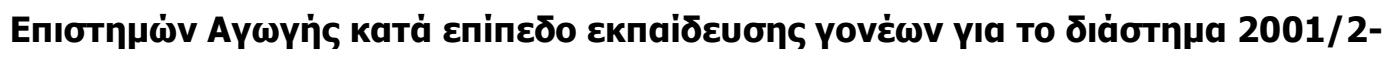
2008/9

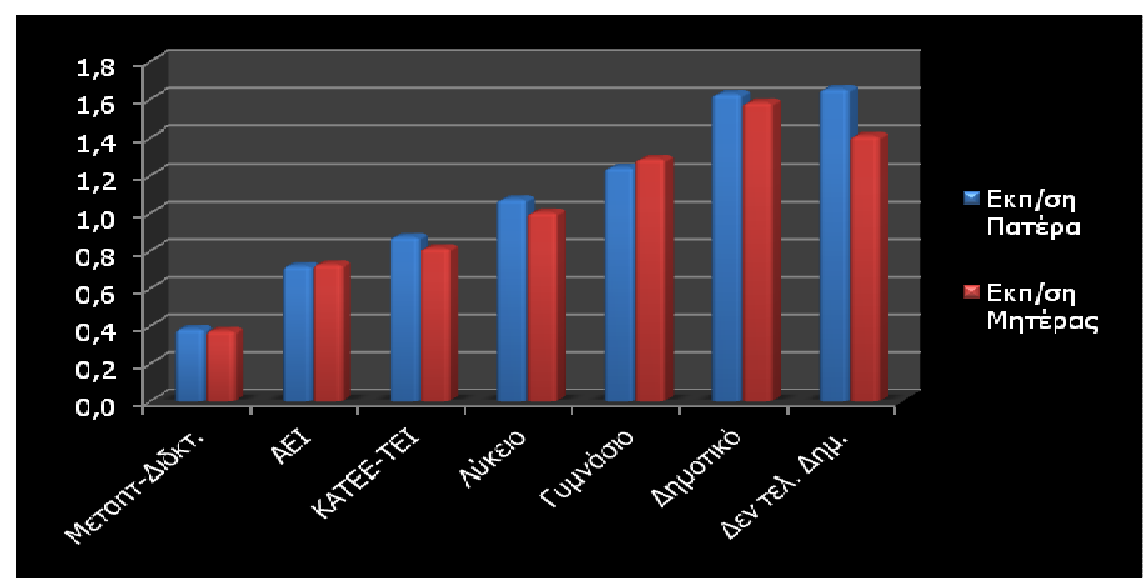

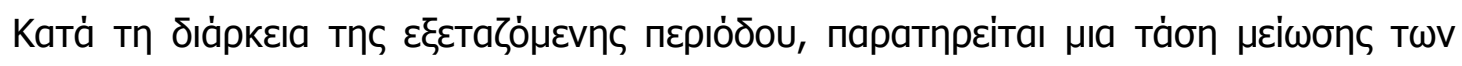

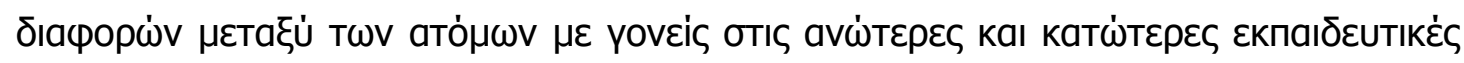

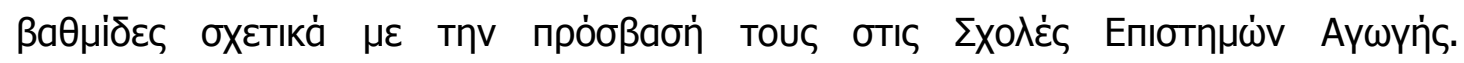

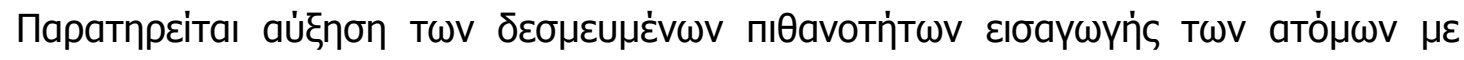

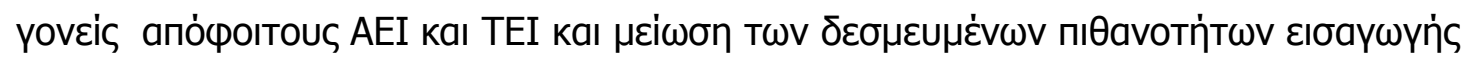

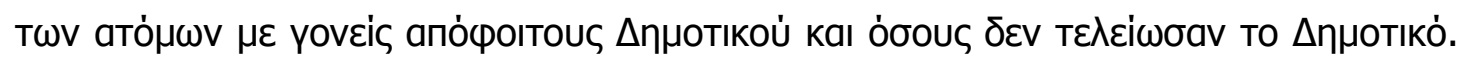

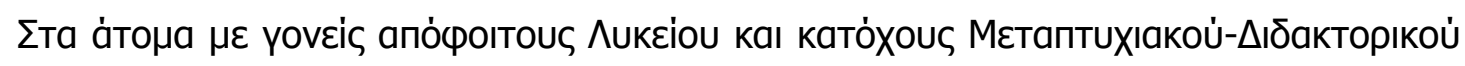

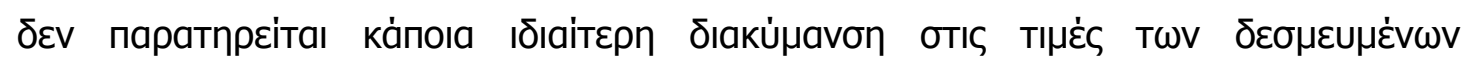

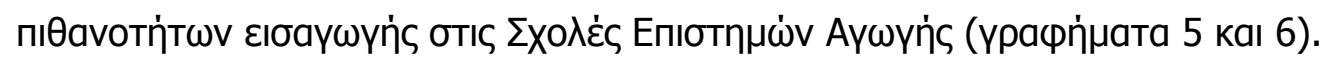

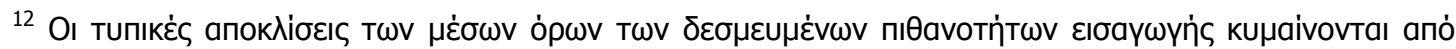

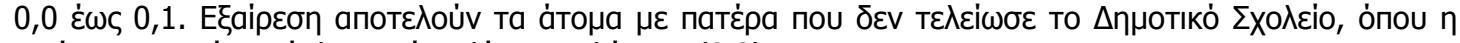

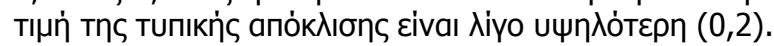




\section{Гра́фпна 5}

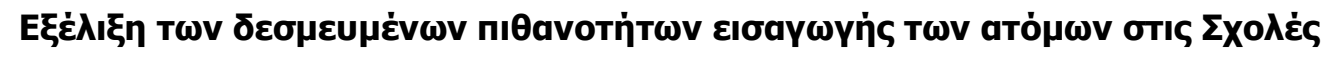

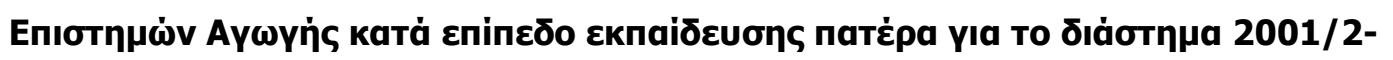

2008/9

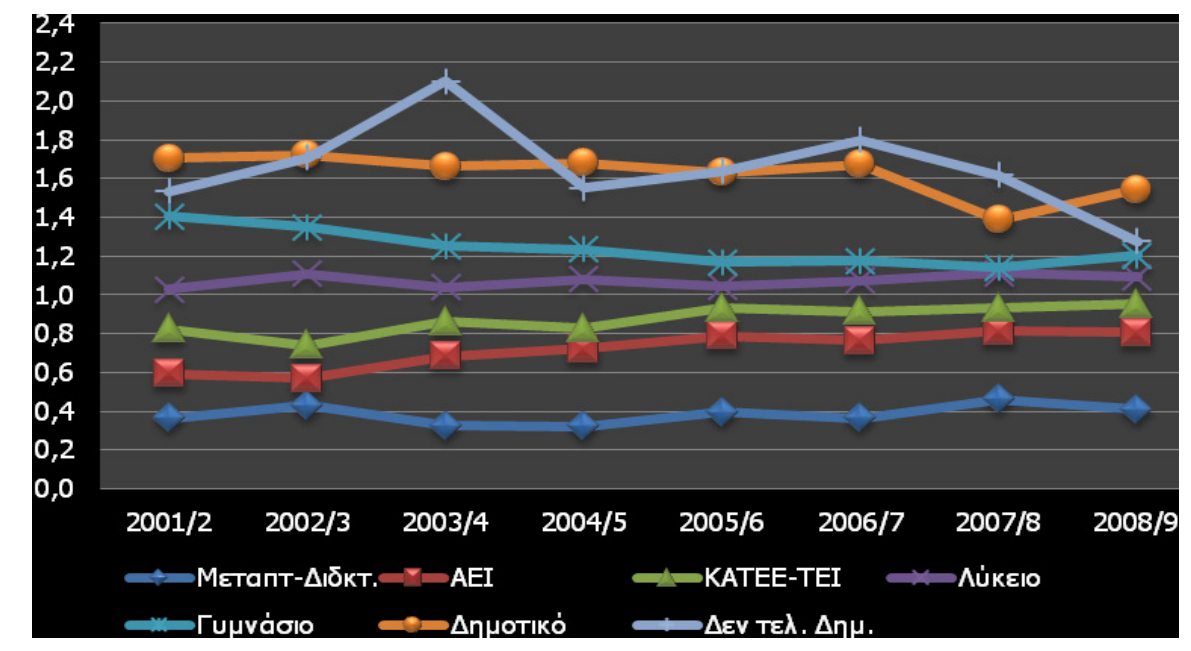

Гра́фnнa 6

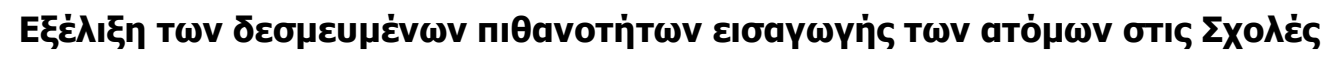

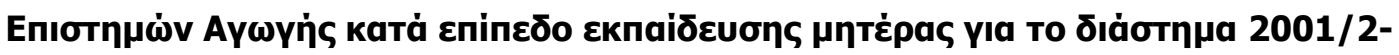
2008/9

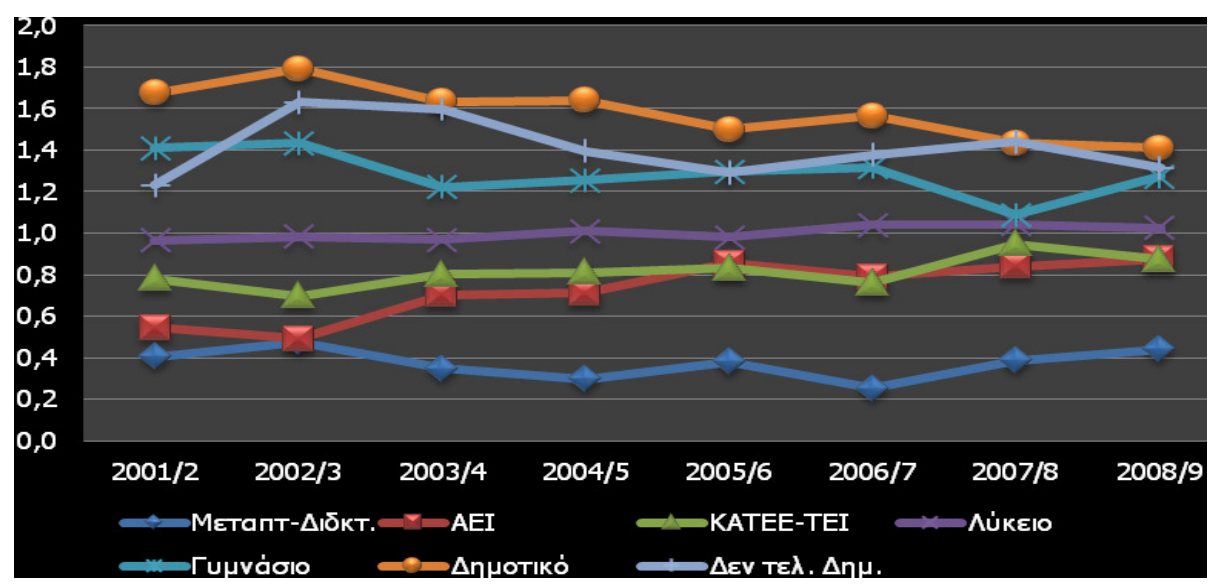

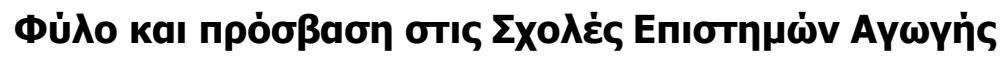

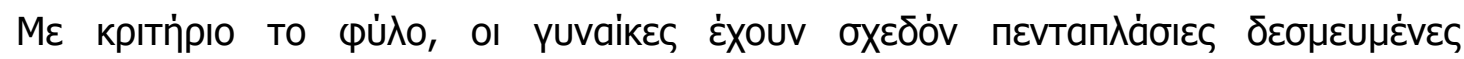

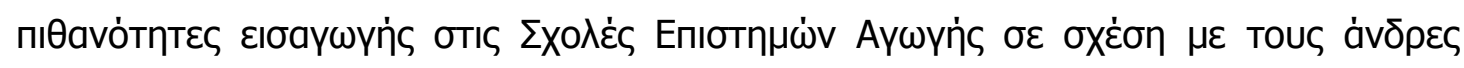

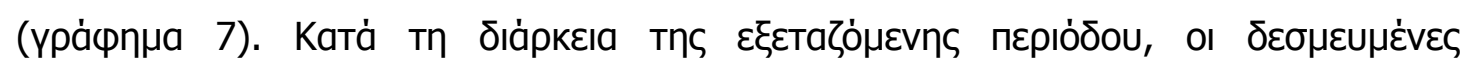

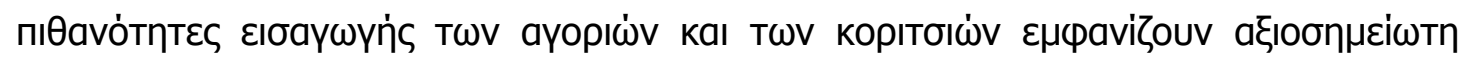

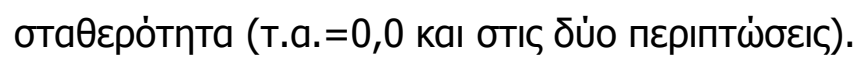




\section{Гра́фрна 7}

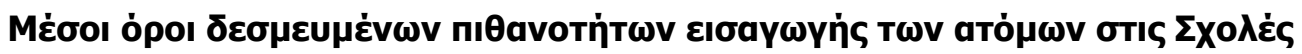

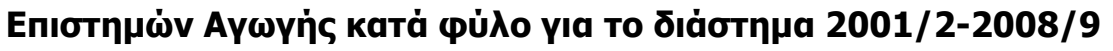

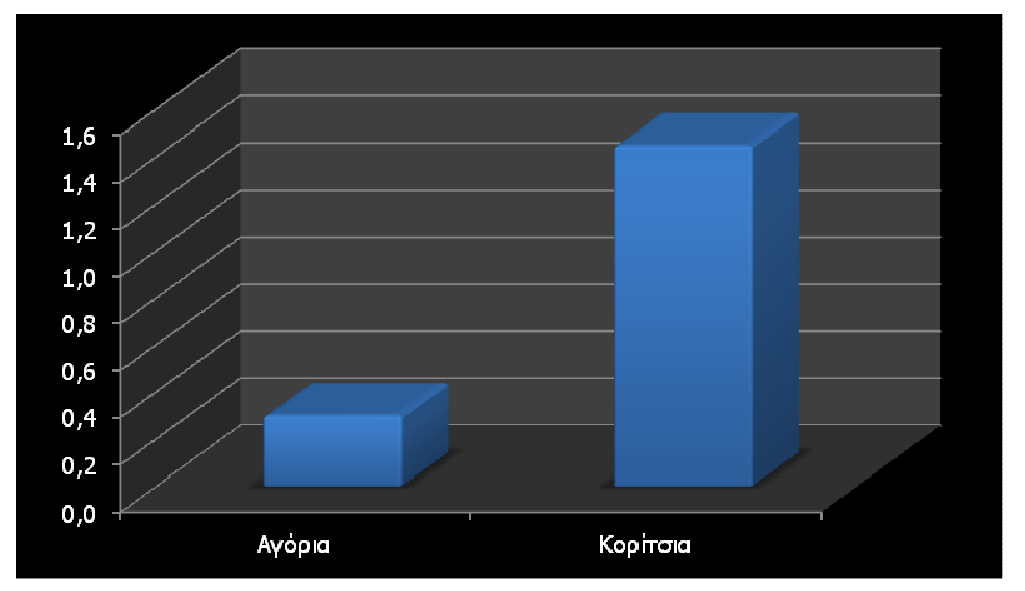

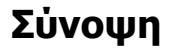

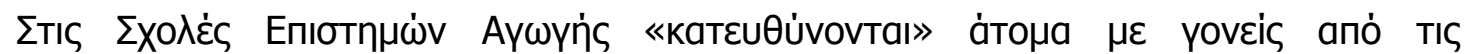

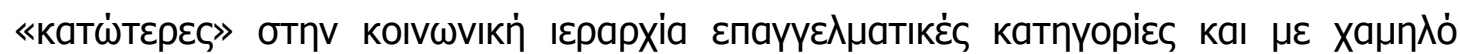

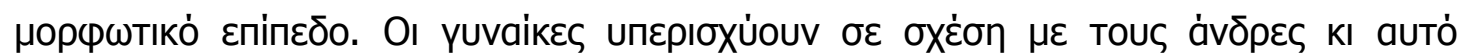

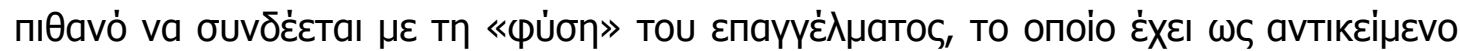

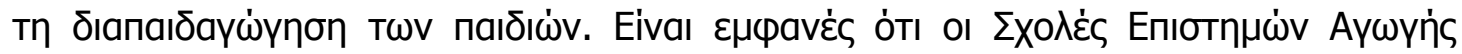

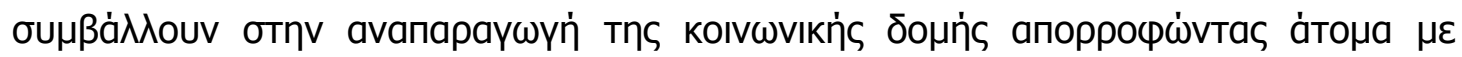

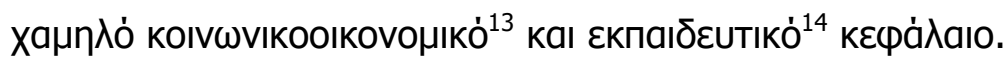

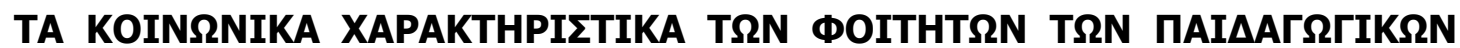

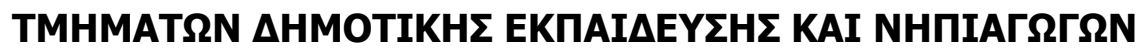

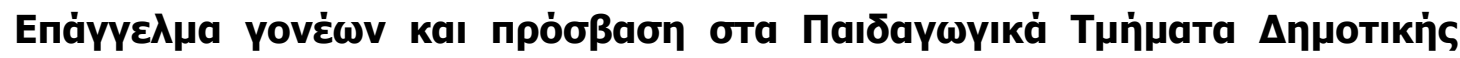

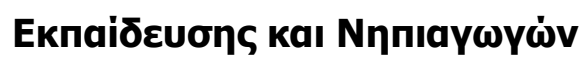

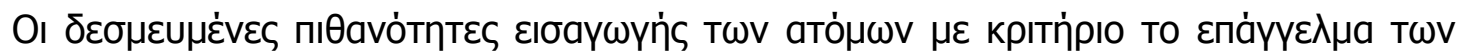

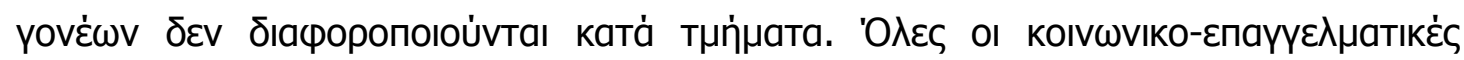

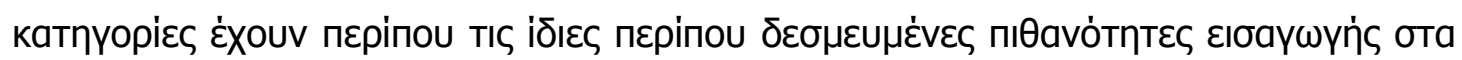

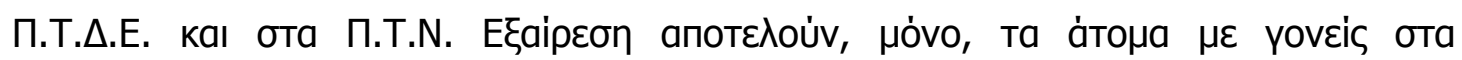

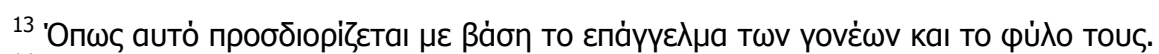

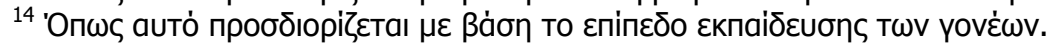




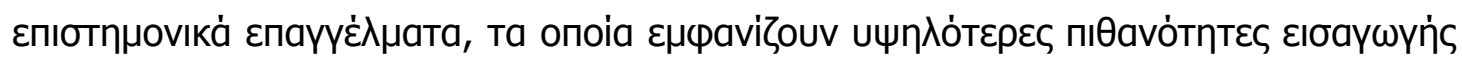

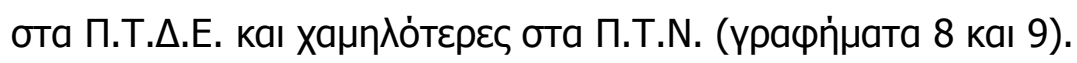

\section{Гра́фпна 8}

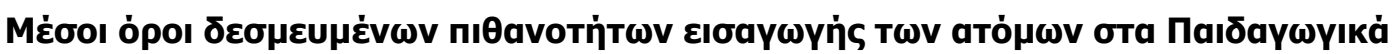

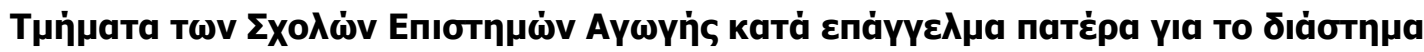
2001/2-2008/9

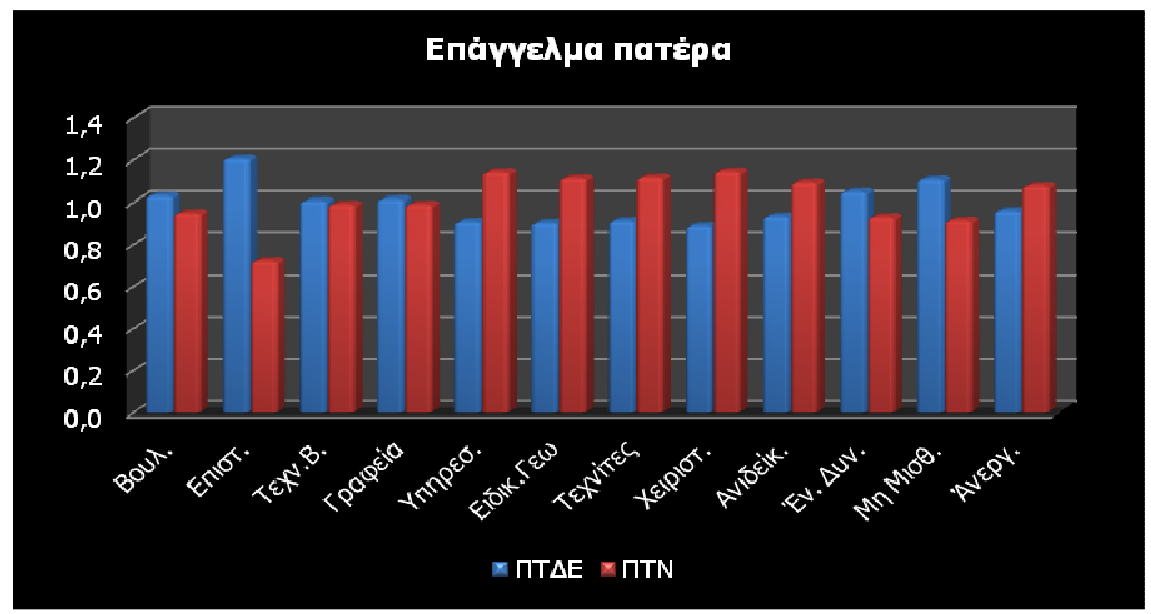

Гра́фпна 9

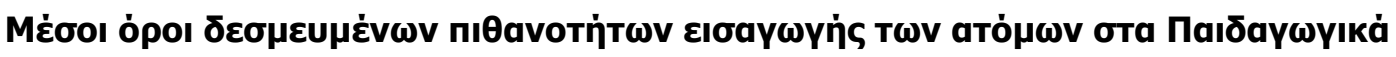

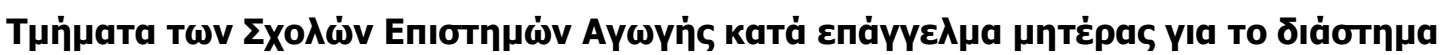
2001/2-2008/9

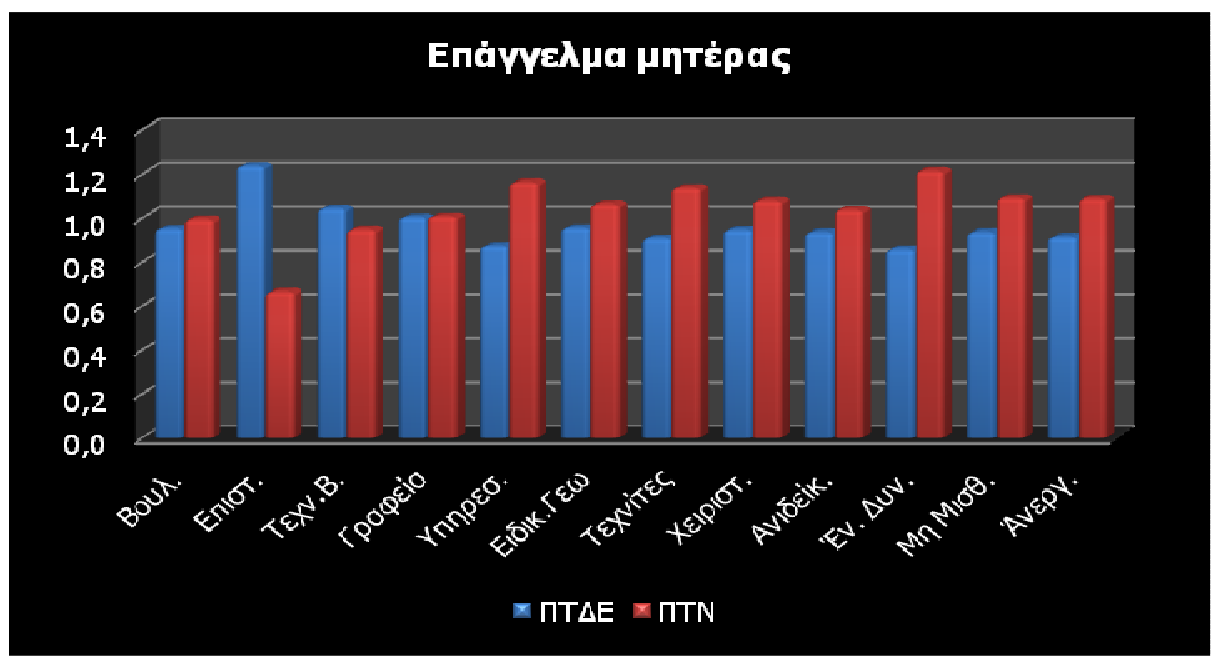




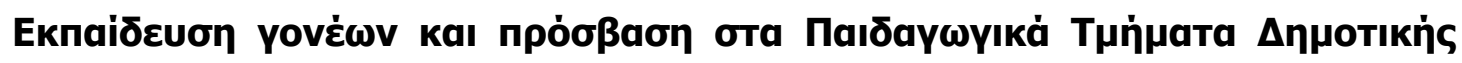

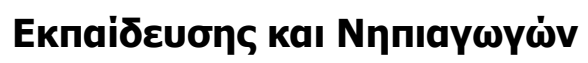

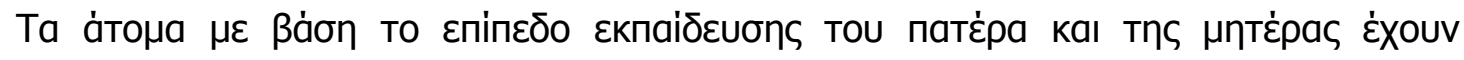

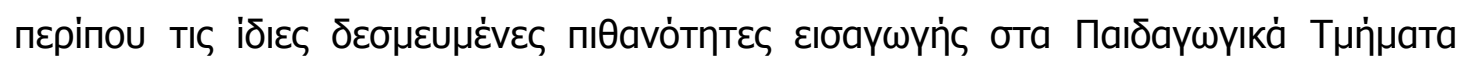

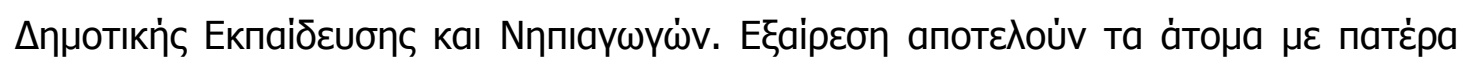

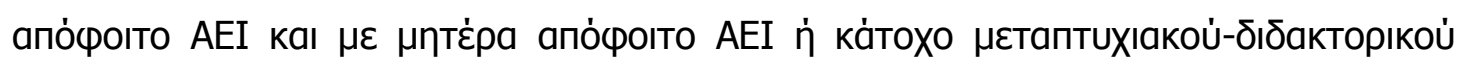

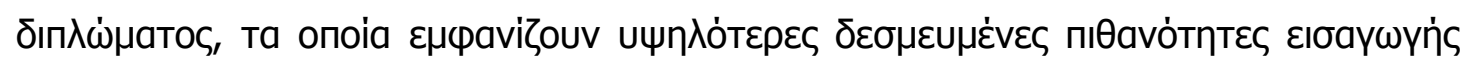

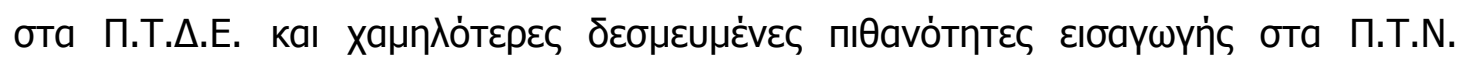
(үрафйната 10 ка 11).

\section{Гра́甲пна 10}

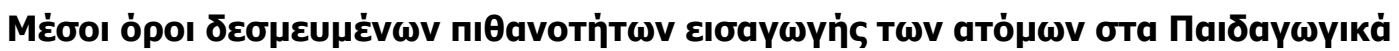

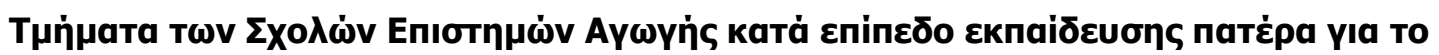
ठı่́otqua 2001/2-2008/9

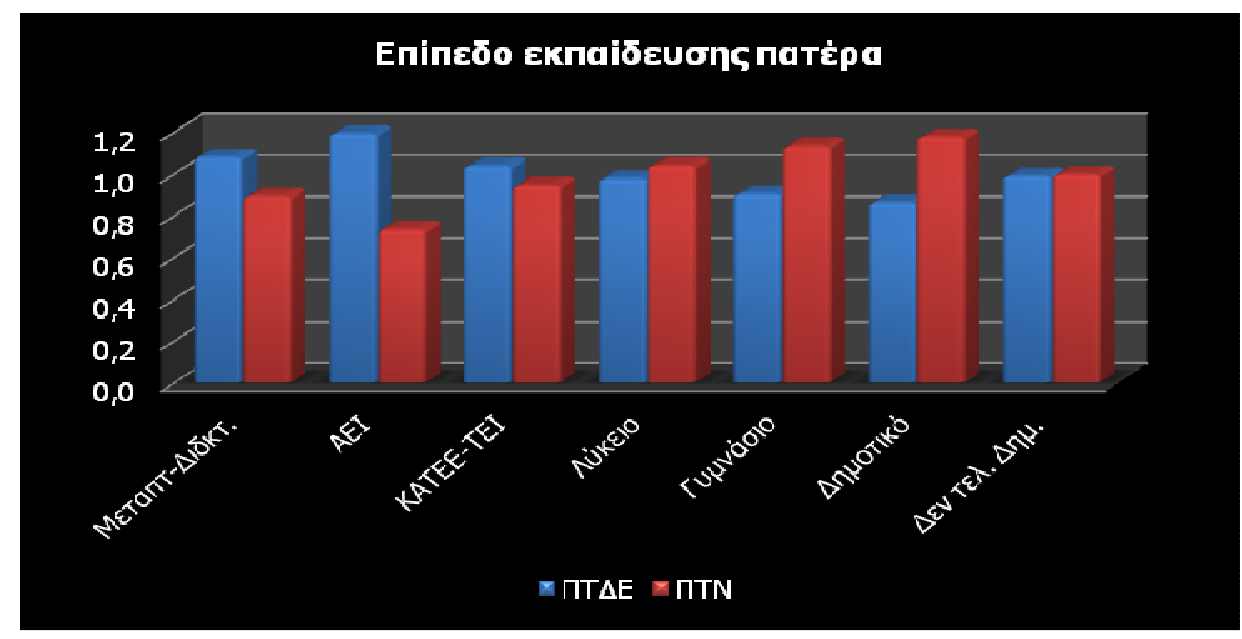

Гра́фпна 11

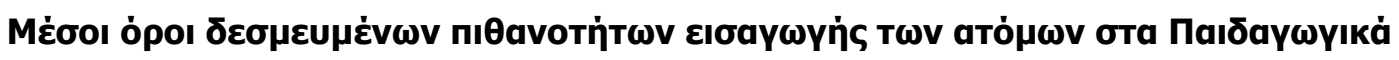

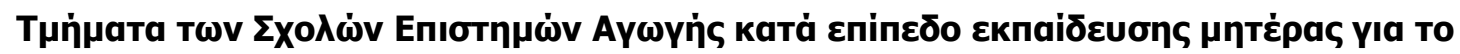

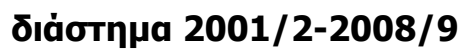




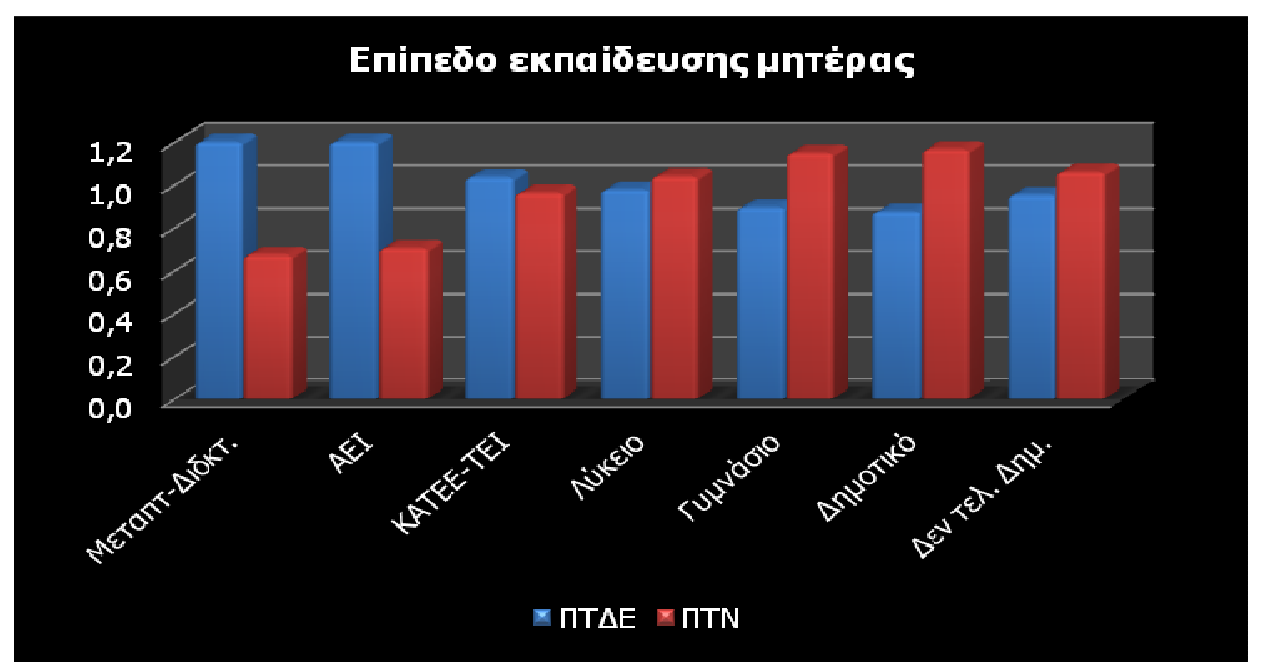

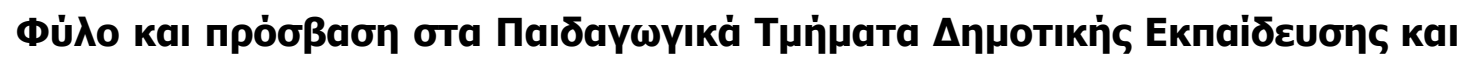
Nnnıaywyóv

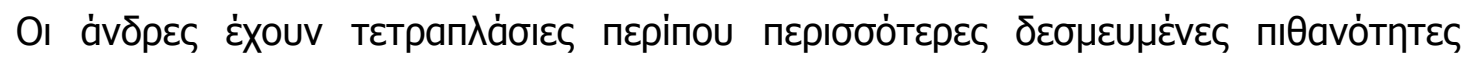

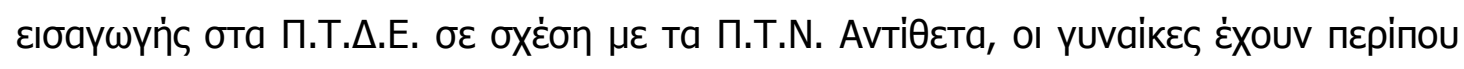

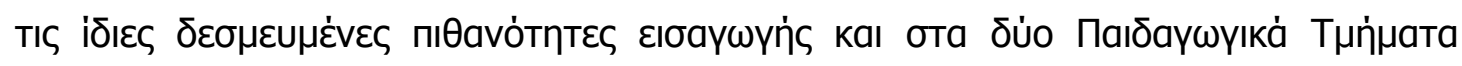
(үра́фпна 12).

\section{Гра́фпна 12}

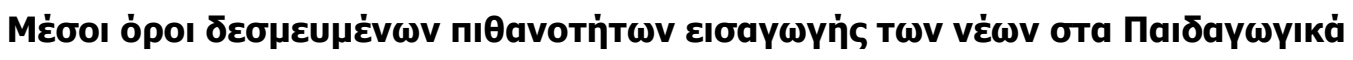

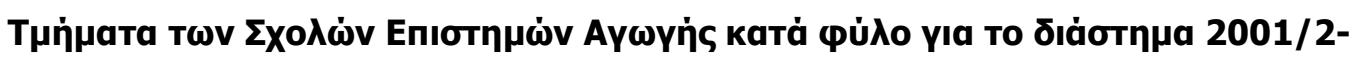
2008/9

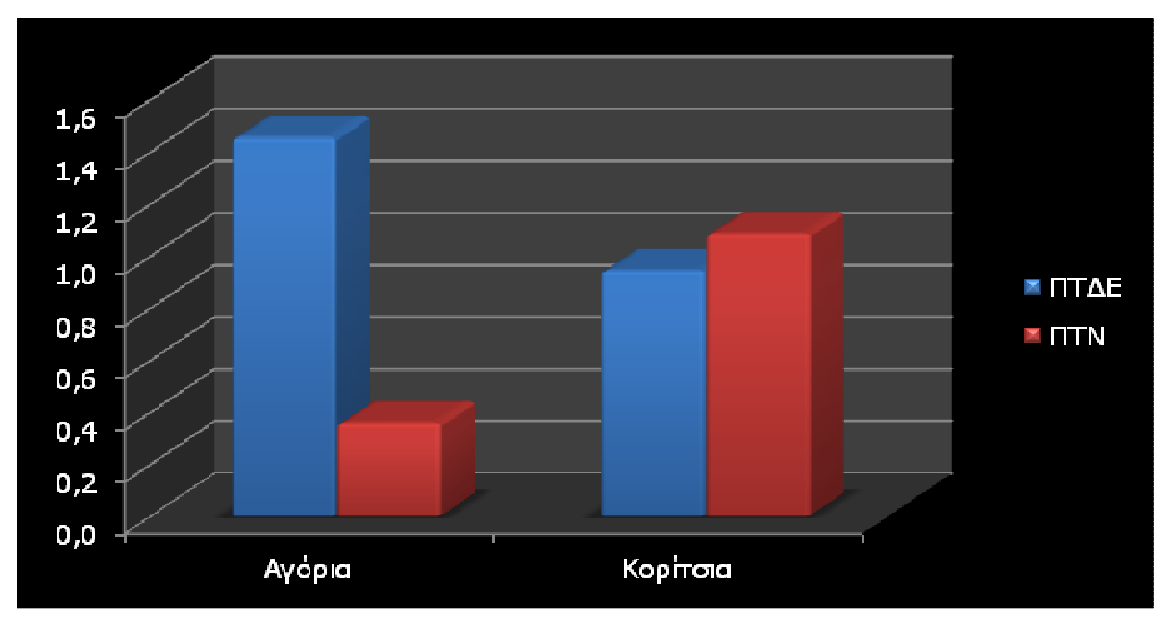

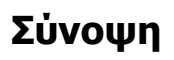

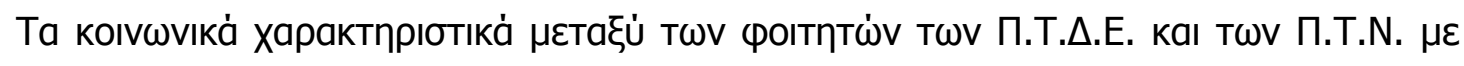

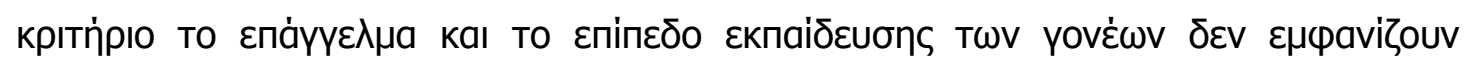




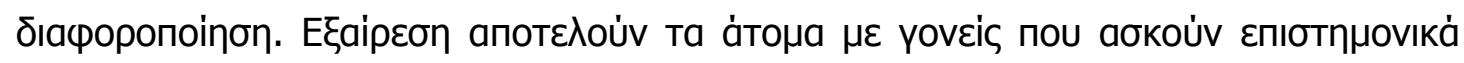

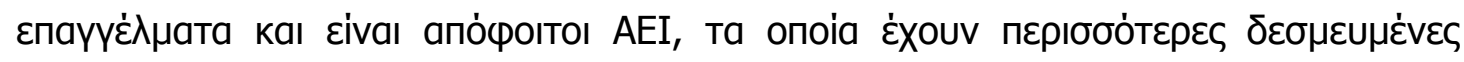

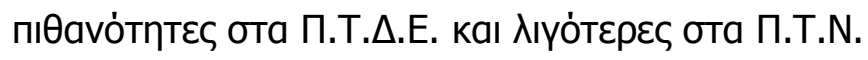

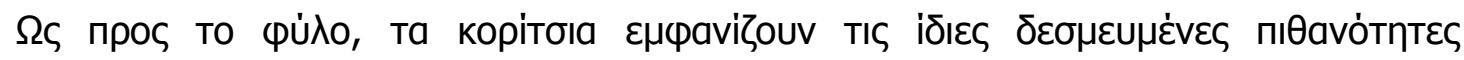

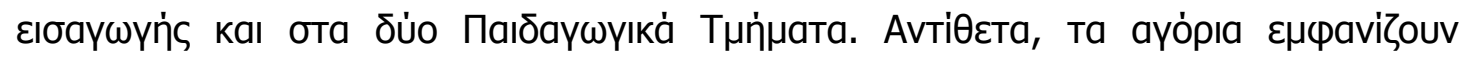

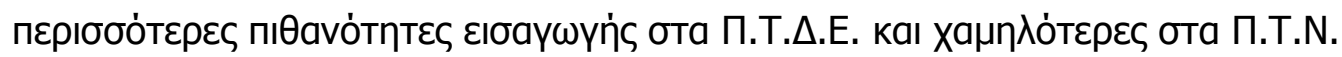




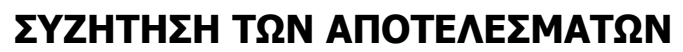

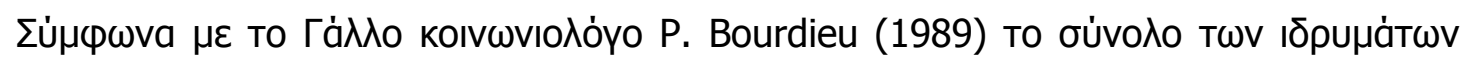

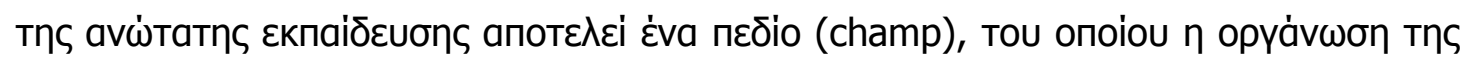

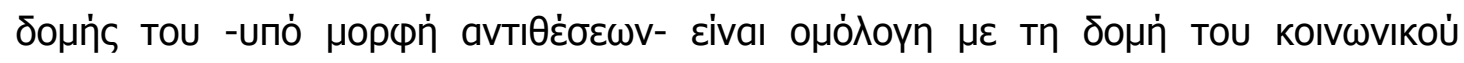

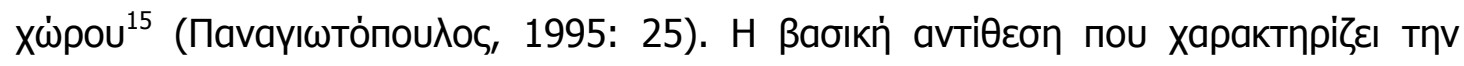

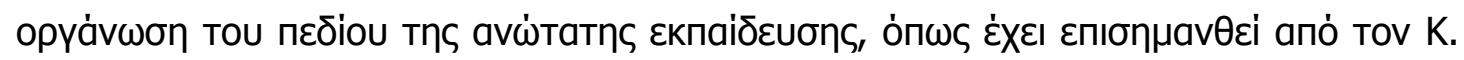

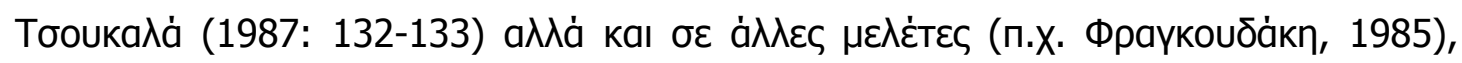

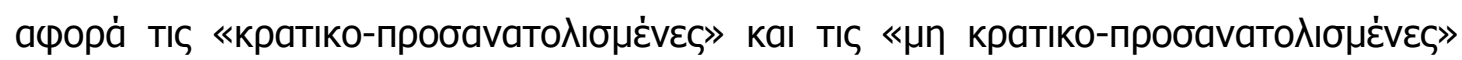

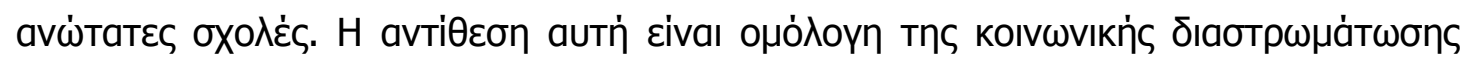

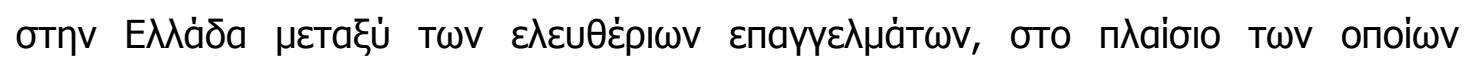

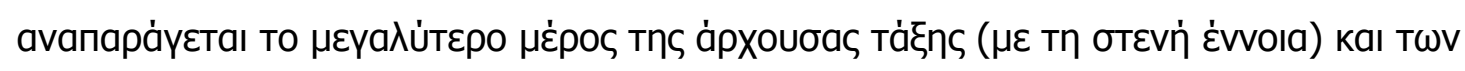

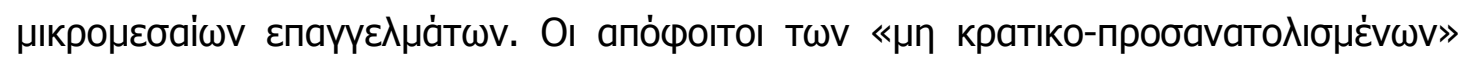

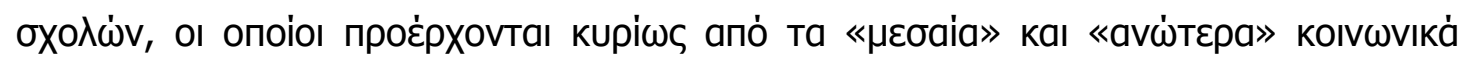

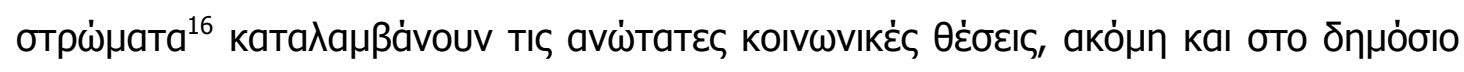

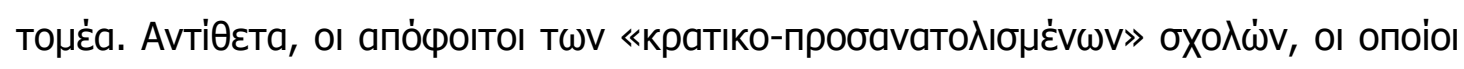

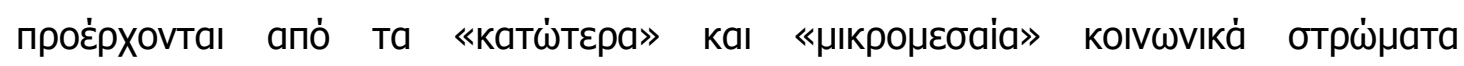

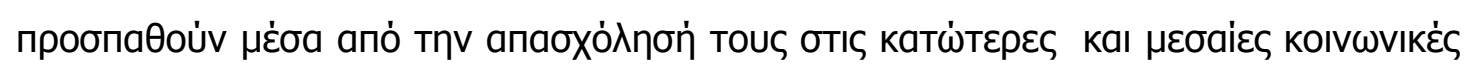

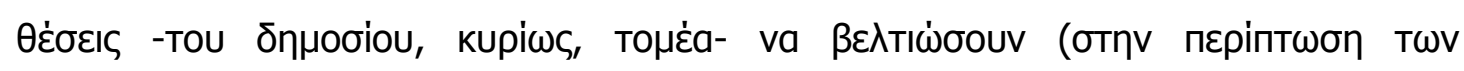

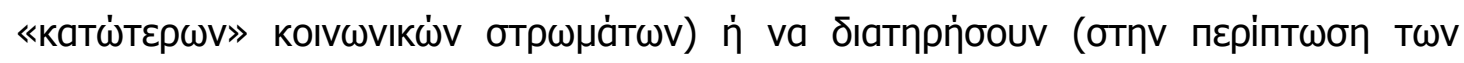

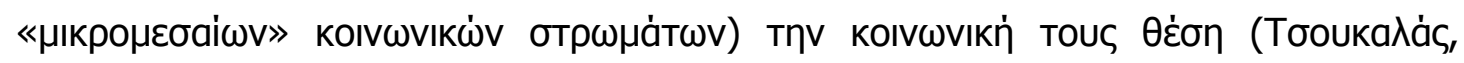
1986: 133. Đávos, 2010: 447-449).

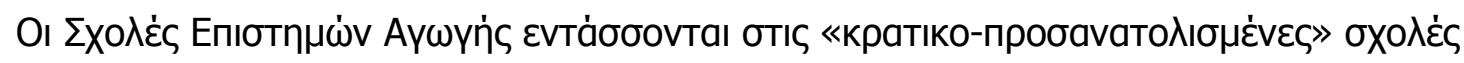

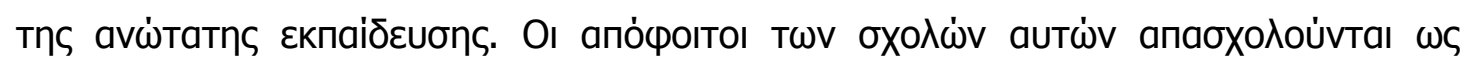

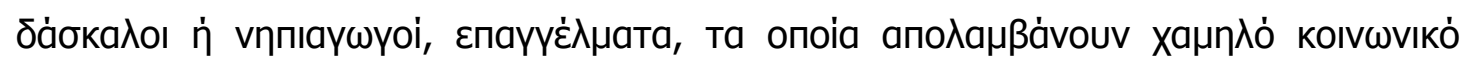

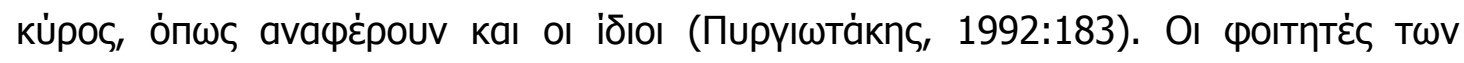

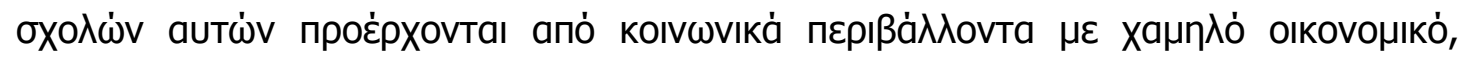

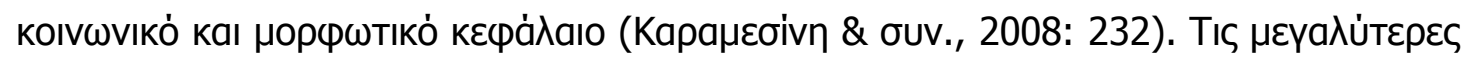

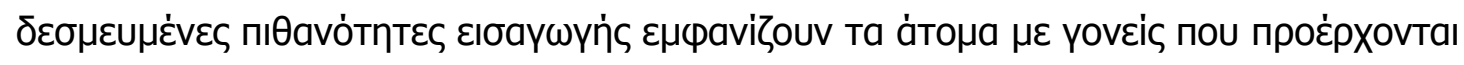

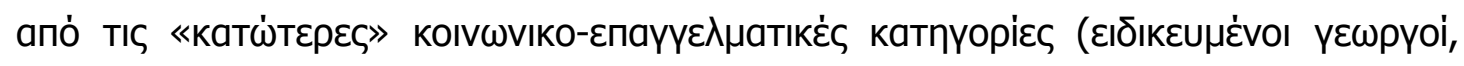

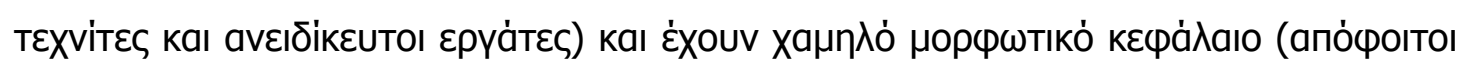

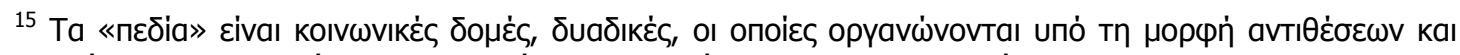

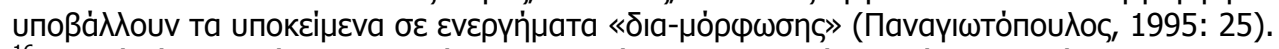

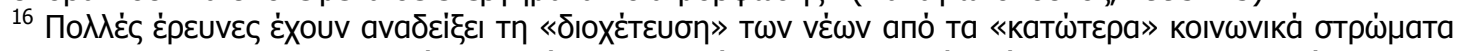

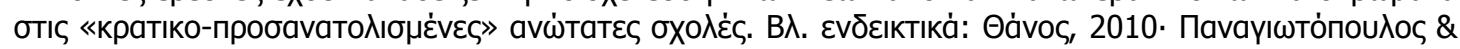

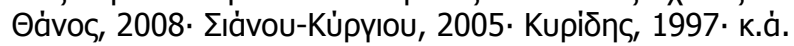




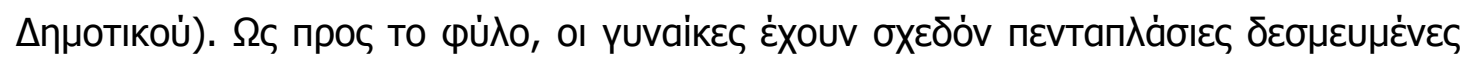

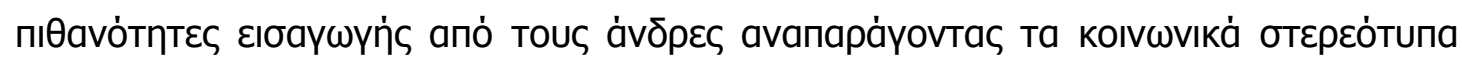

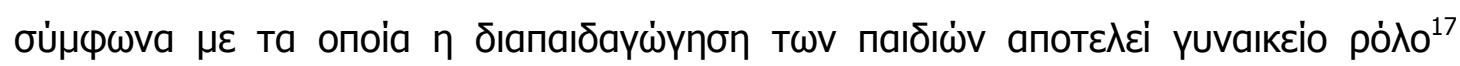
(Arnot, 2004. Reay, 1998).

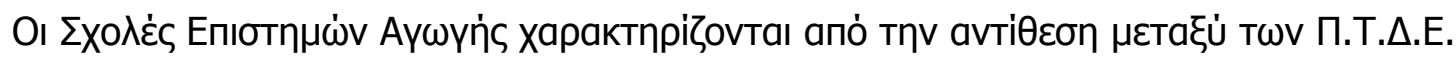

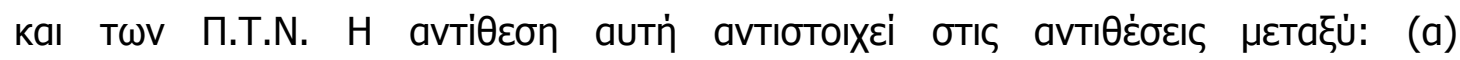

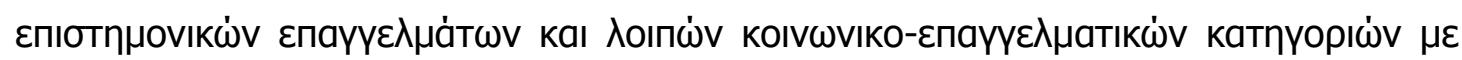

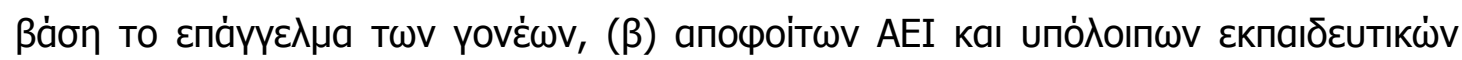

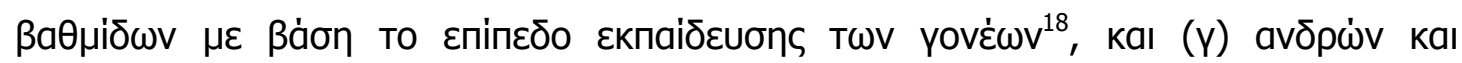

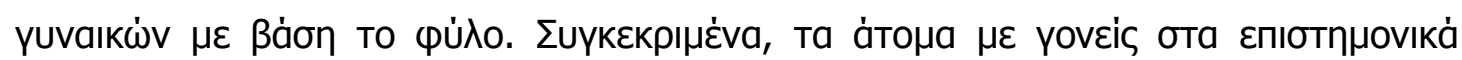

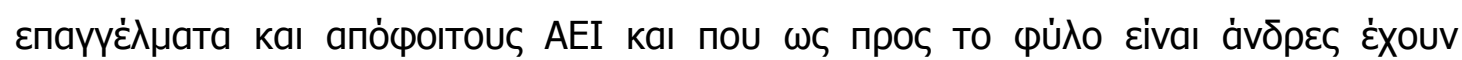

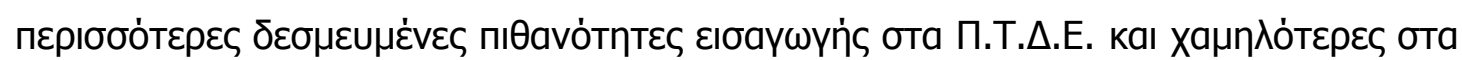
T.T.N.

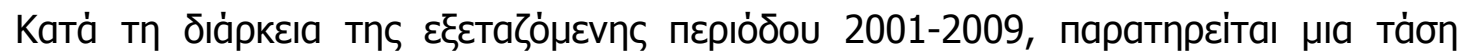

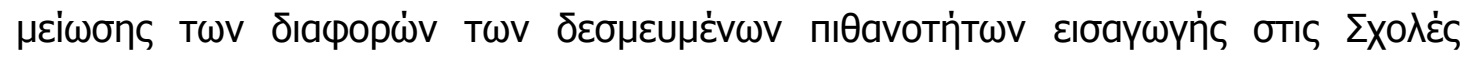

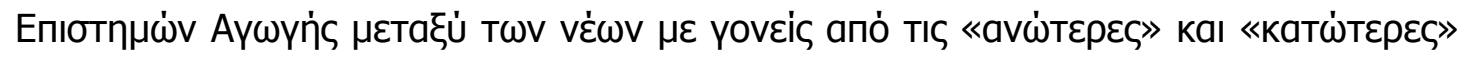

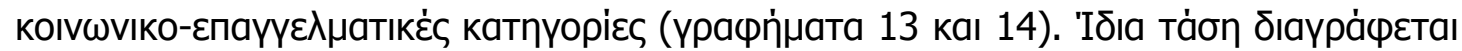

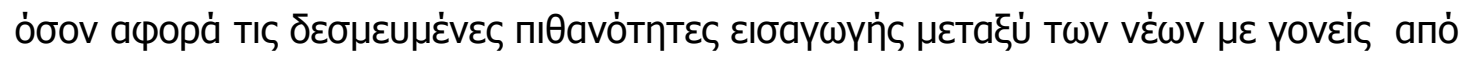

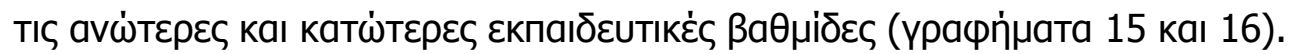

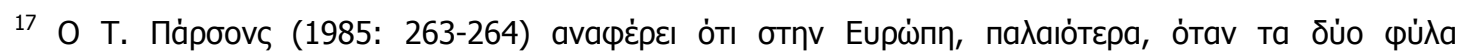

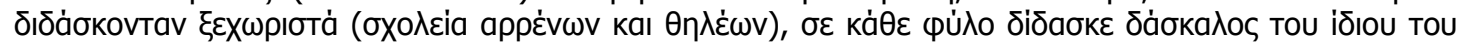

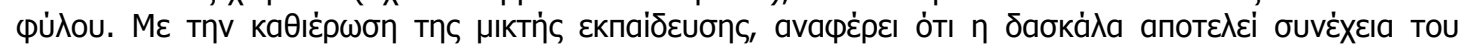

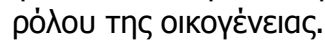

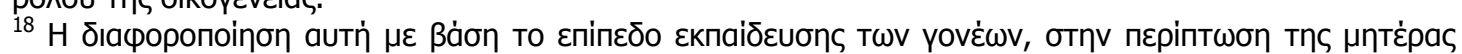

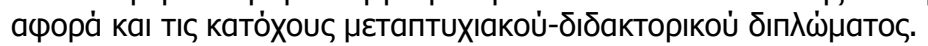




\section{Гра́фпна 13}

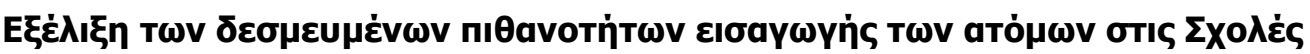

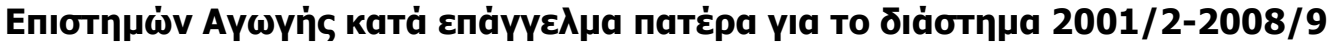

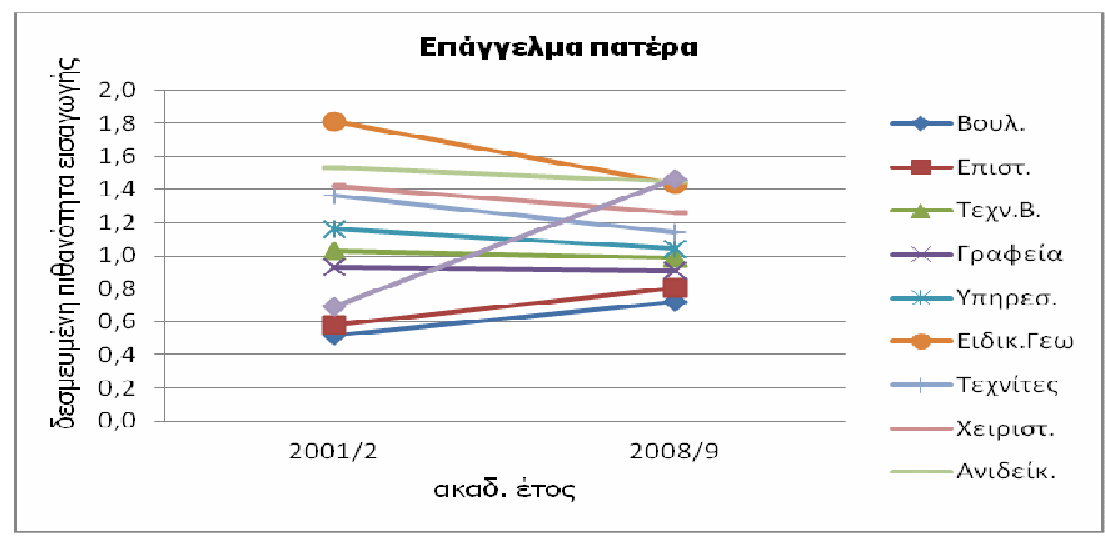

Гра́фпна 14

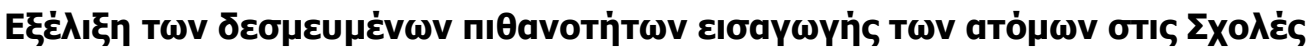

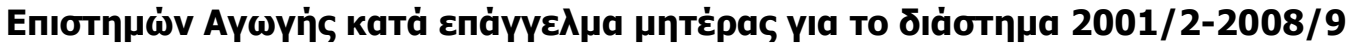

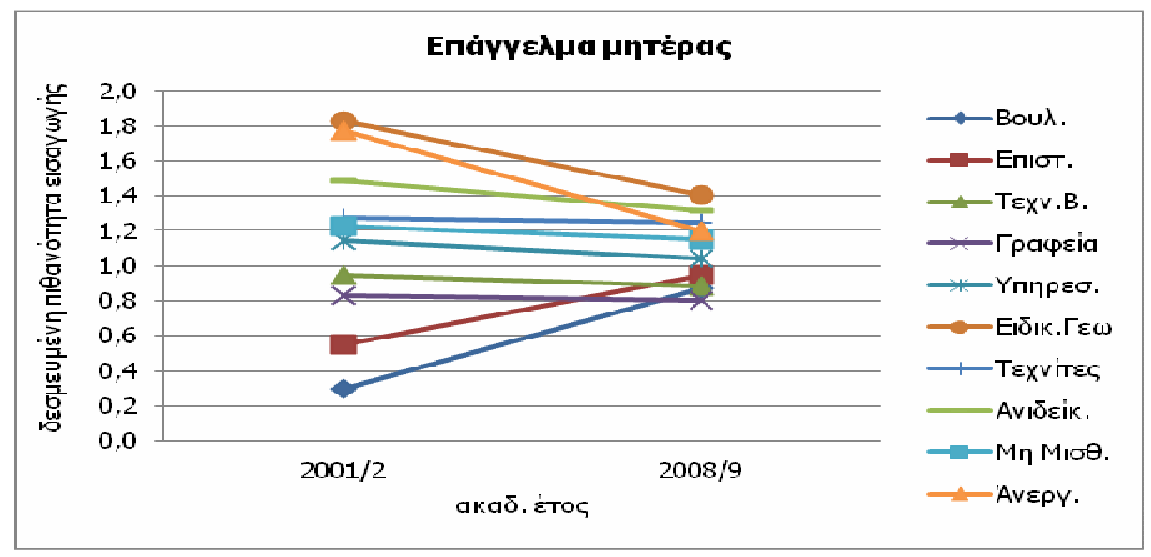




\section{Гра́甲пна 15}

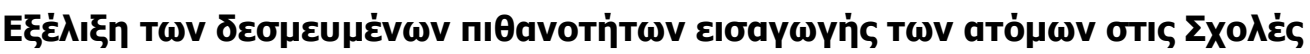

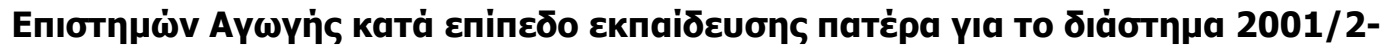
2008/9

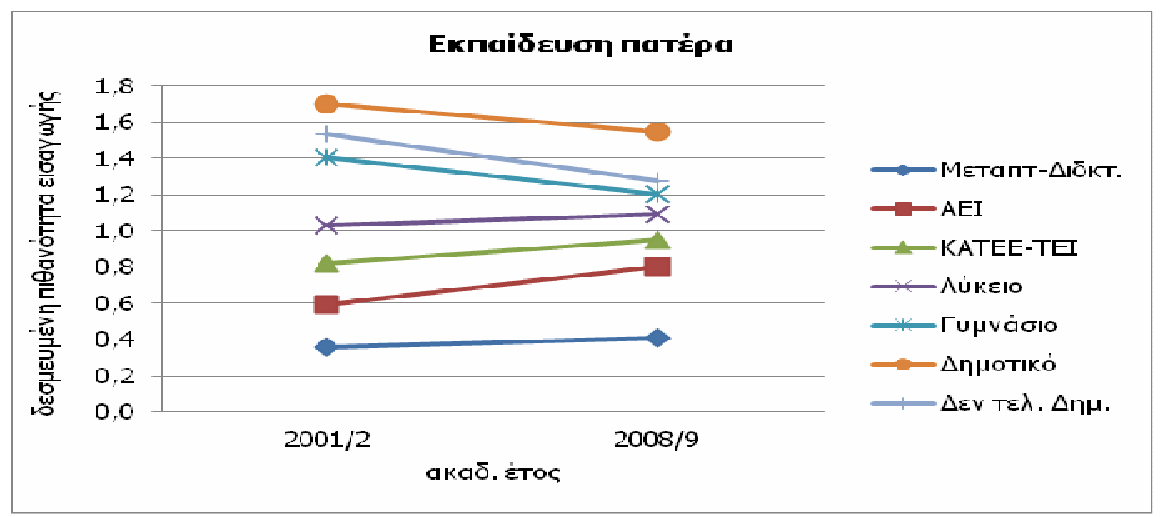

Гра́ழnнa 16

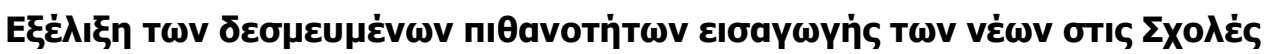

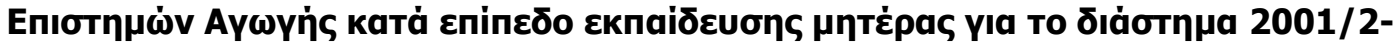
2008/9

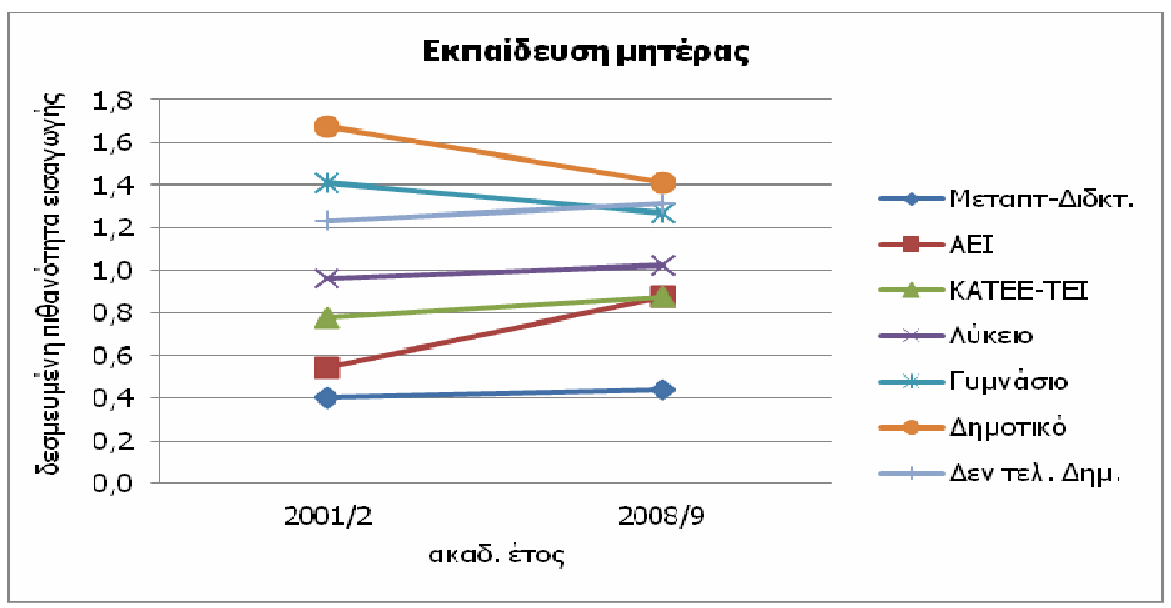

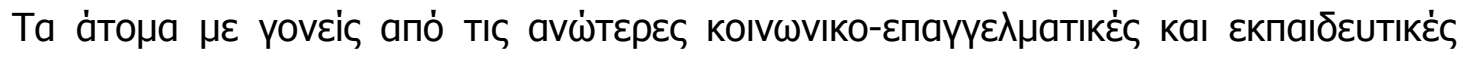

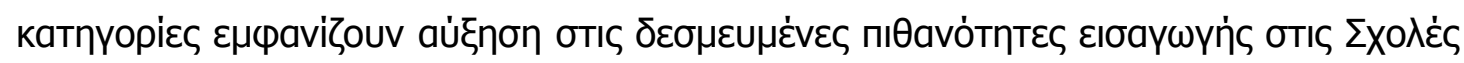

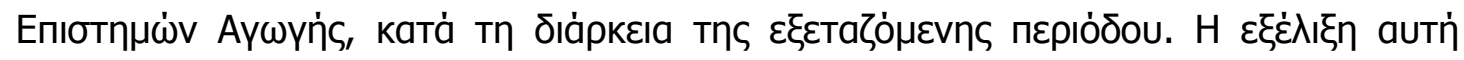

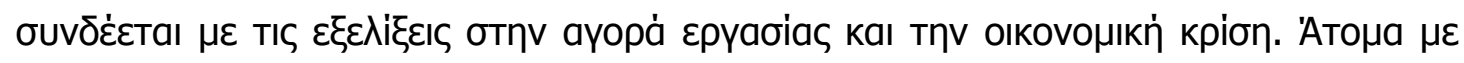

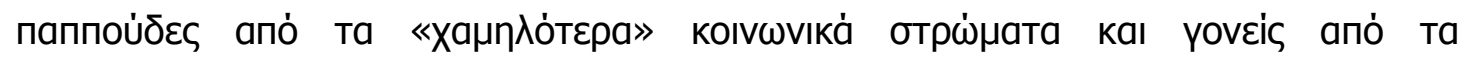

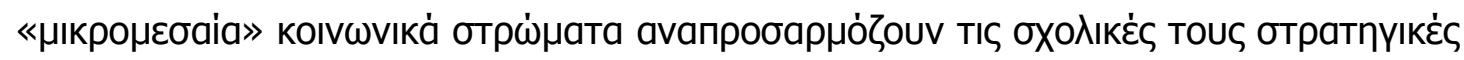

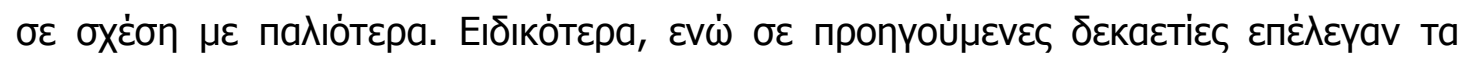

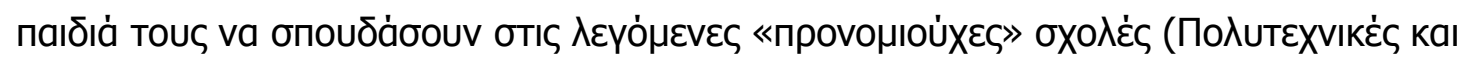




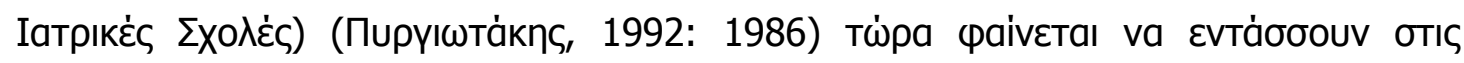

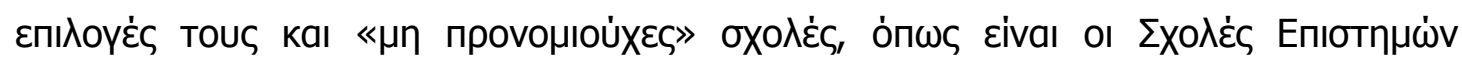

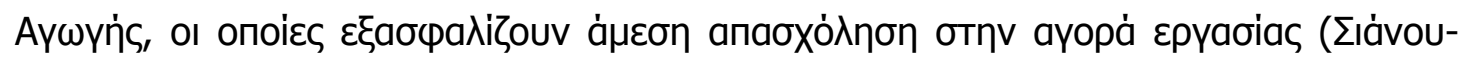

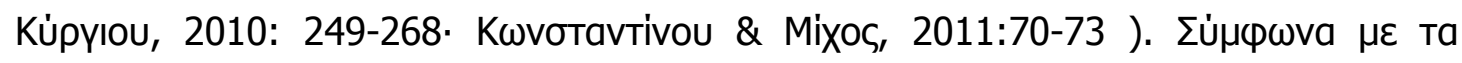

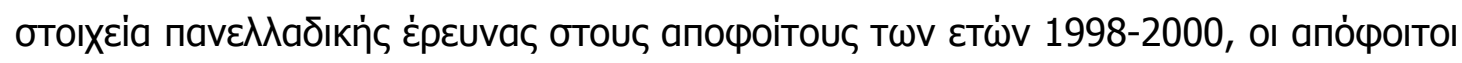

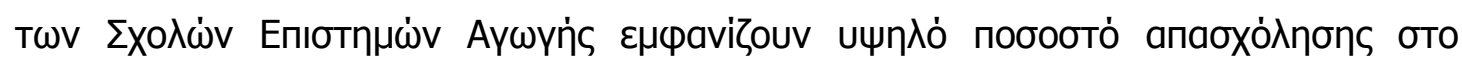

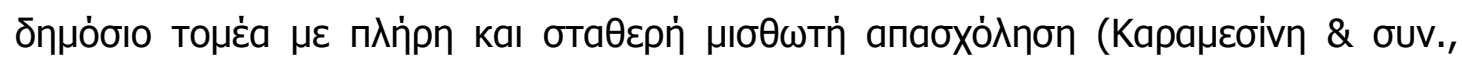

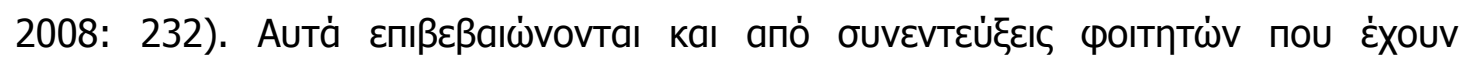

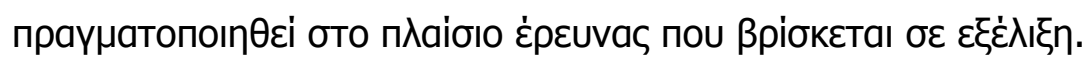

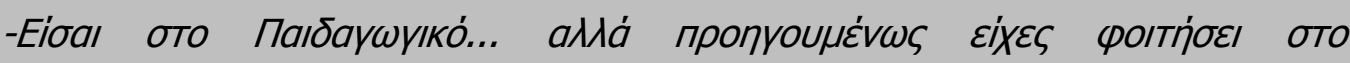
ПоגUTEXVEÍ...

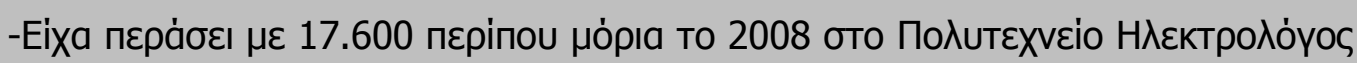

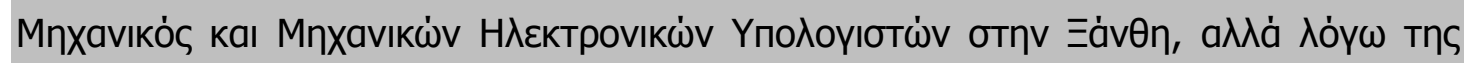

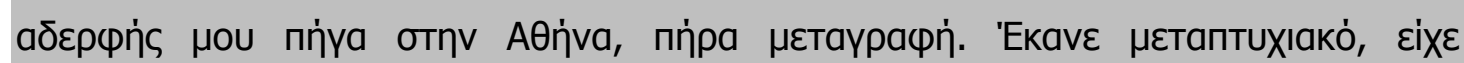

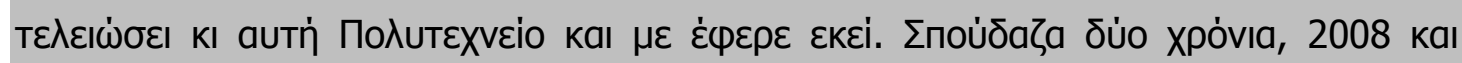

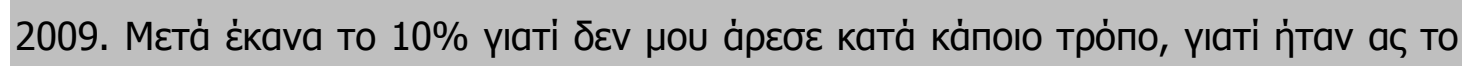

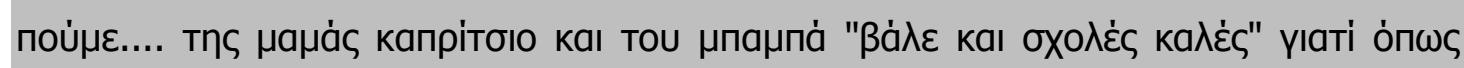

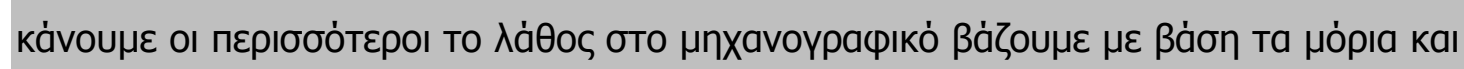

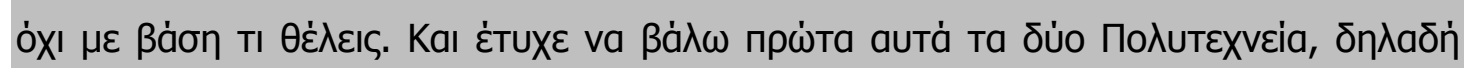

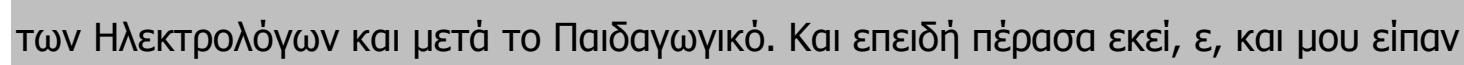

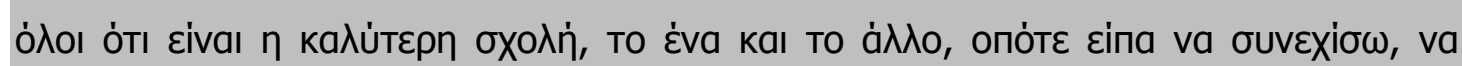

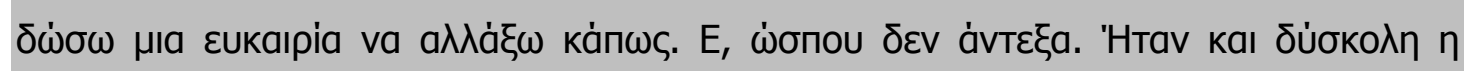

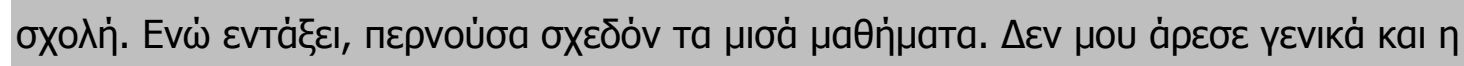

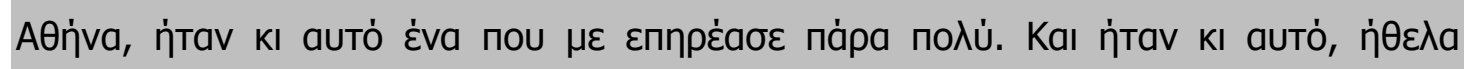

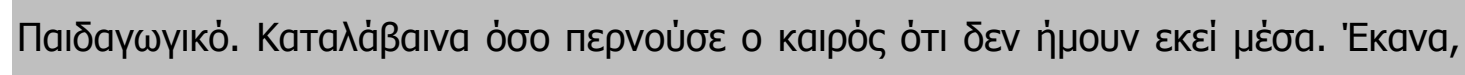

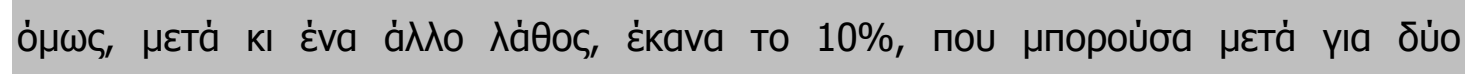

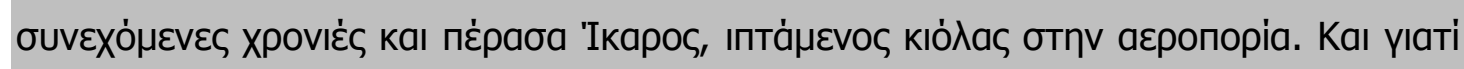

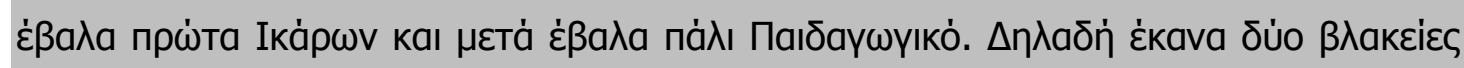

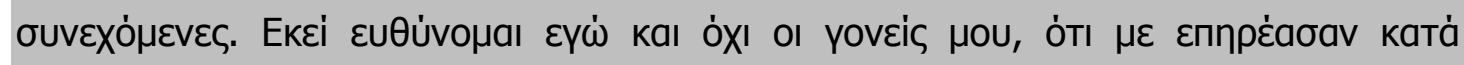

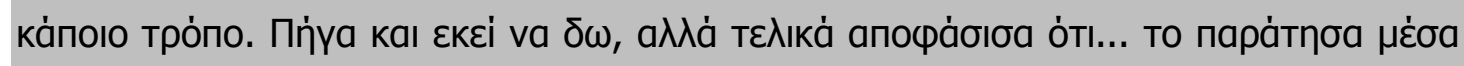

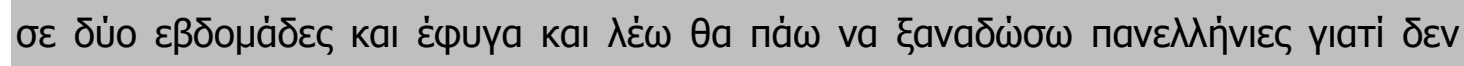

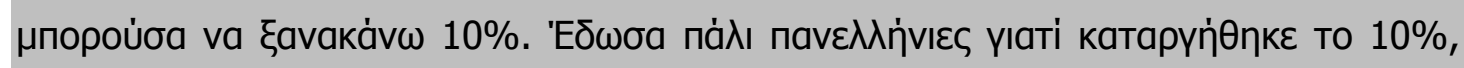

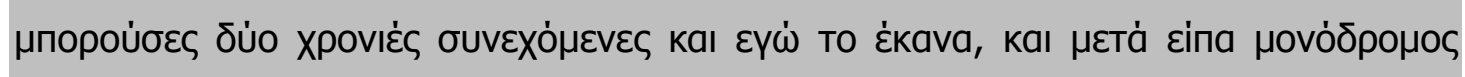




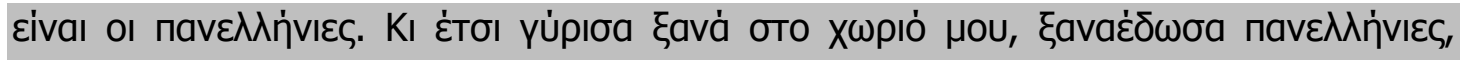

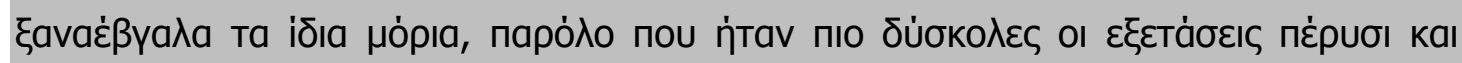

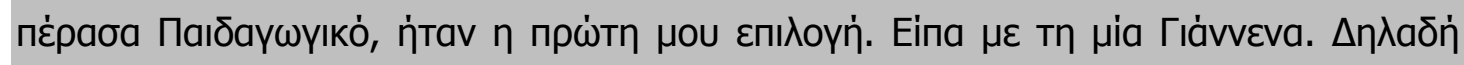

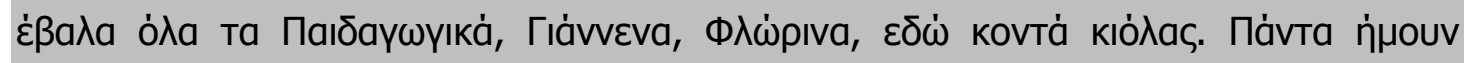

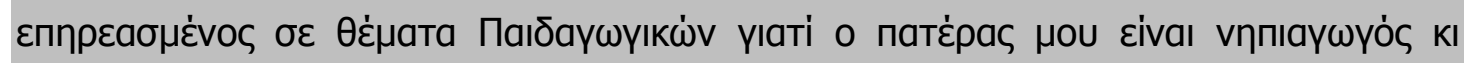

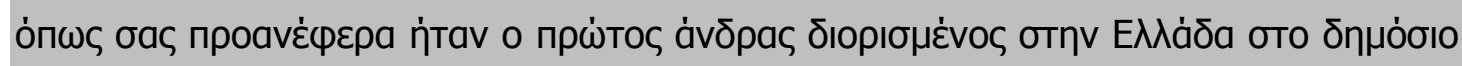

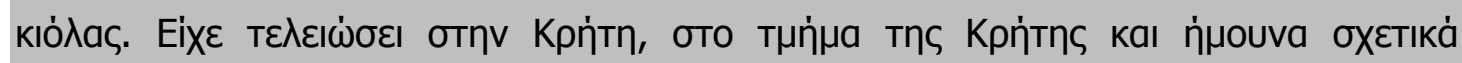

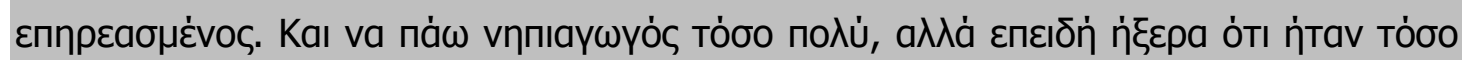

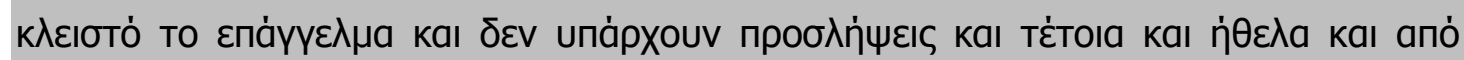

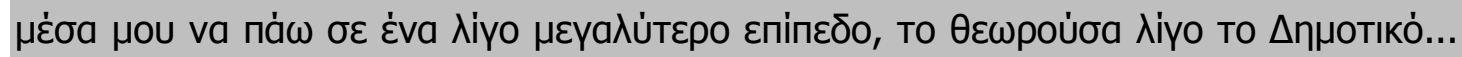

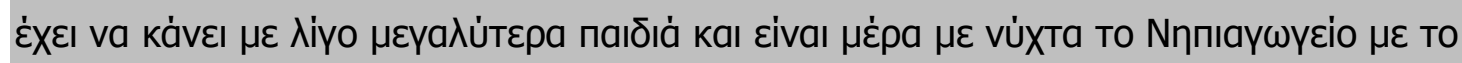

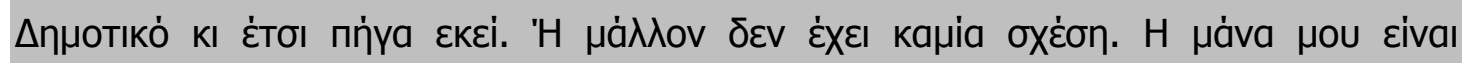

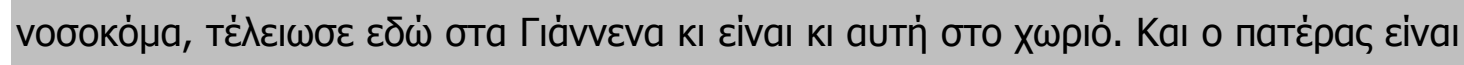

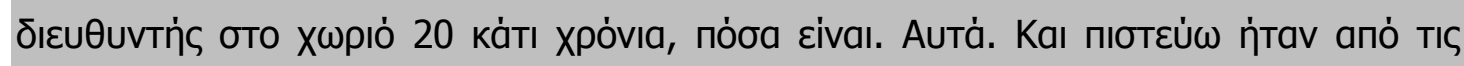

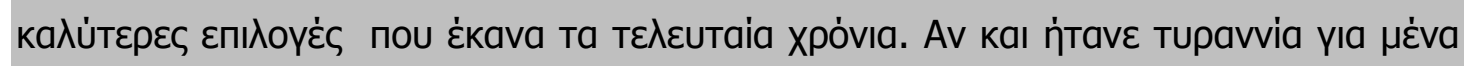

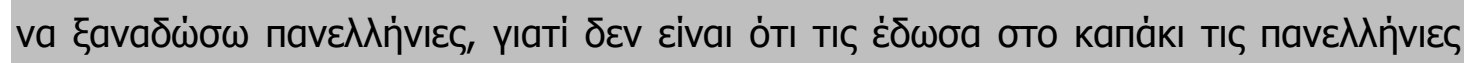

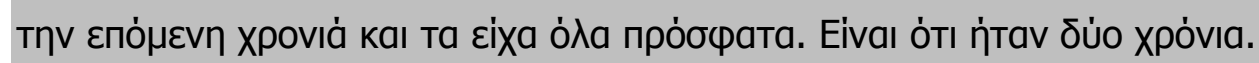

(...)

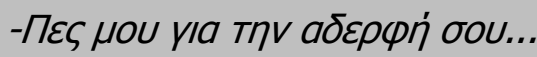

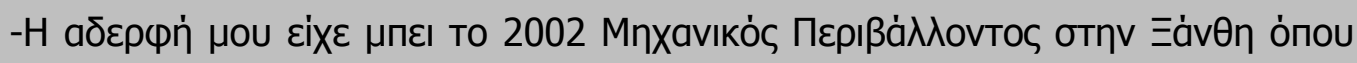

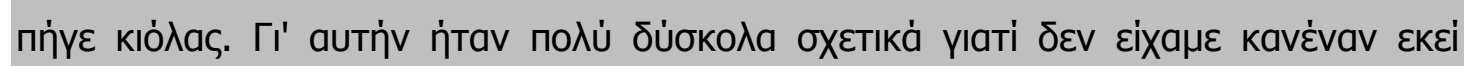

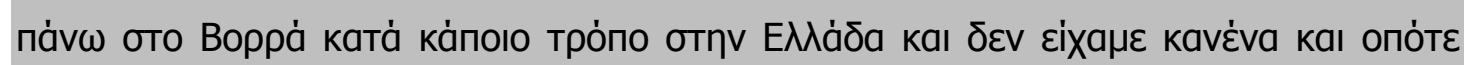

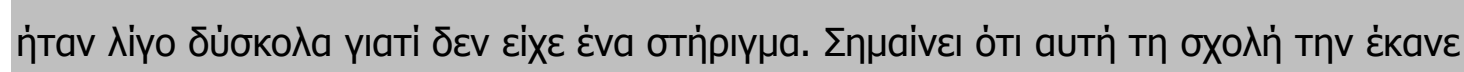

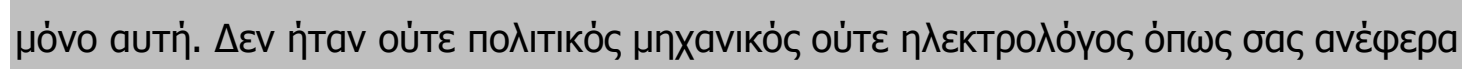

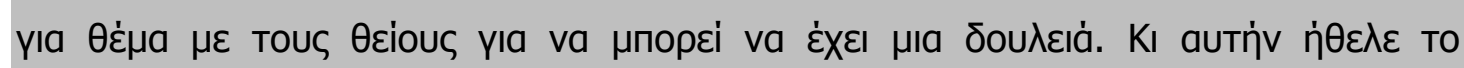

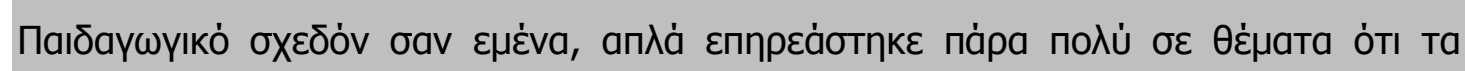

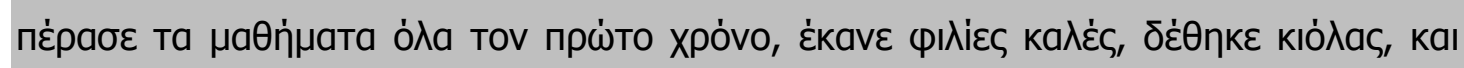

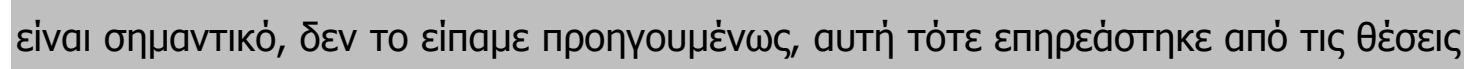

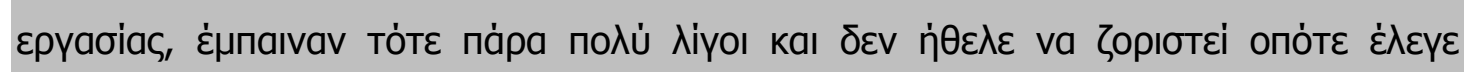

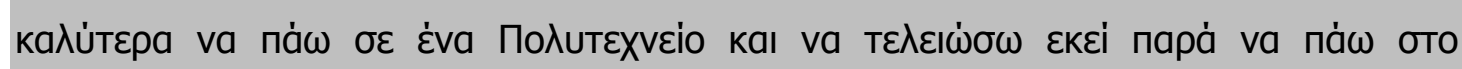
Паıठаү

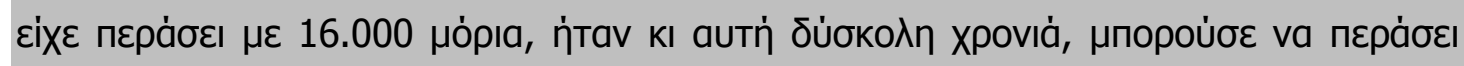

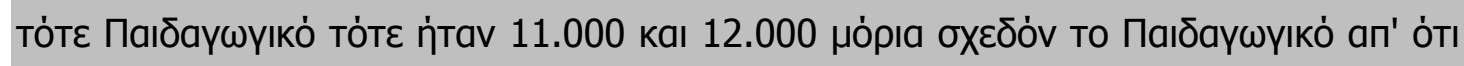

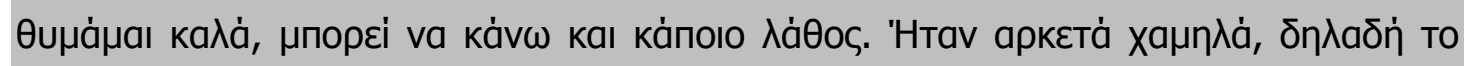

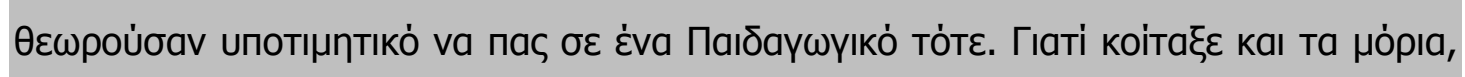




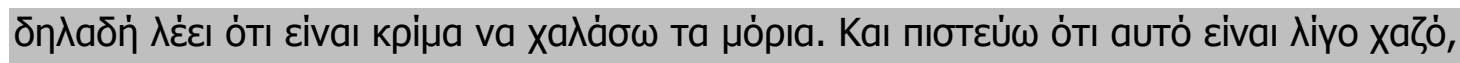

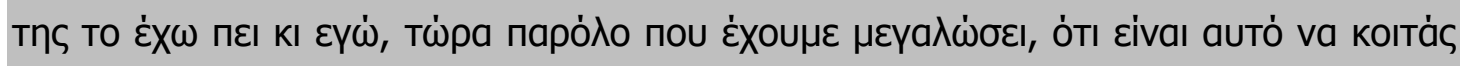

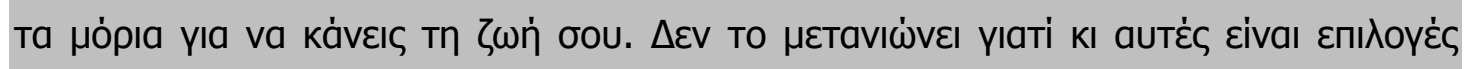

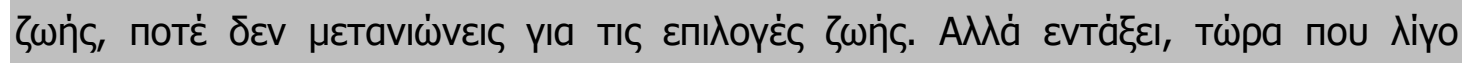

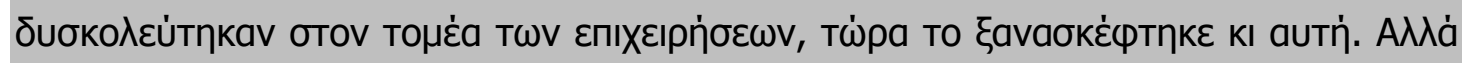

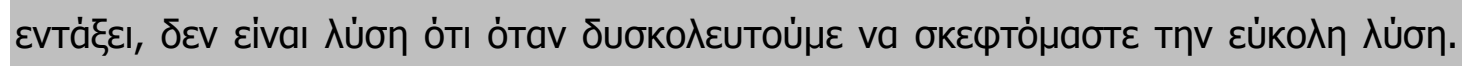

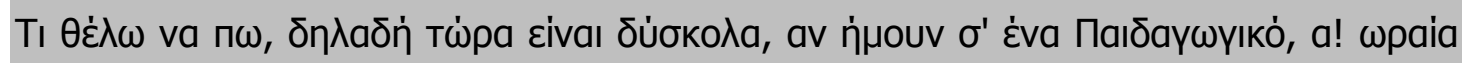

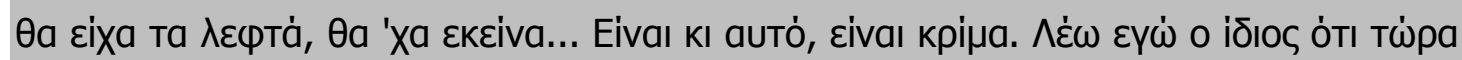

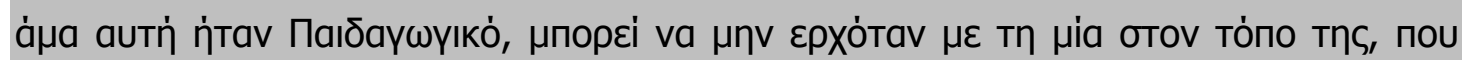

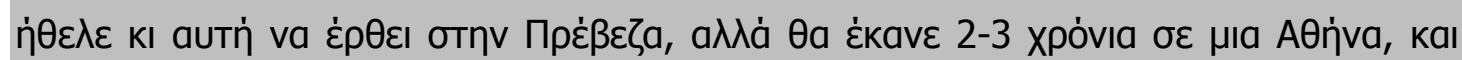

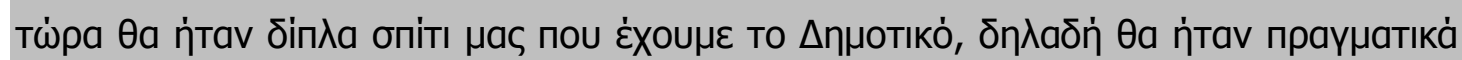

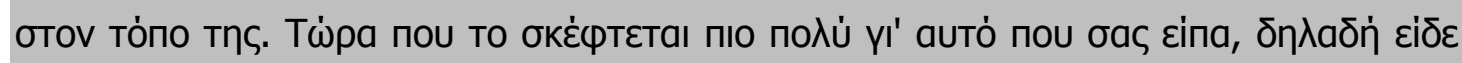

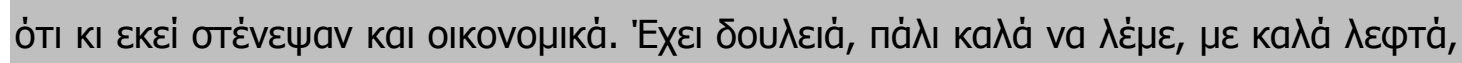

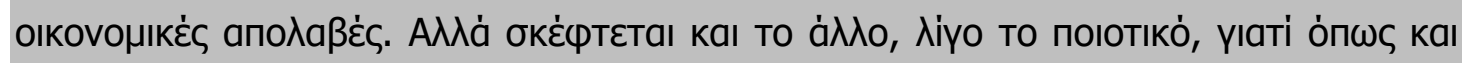

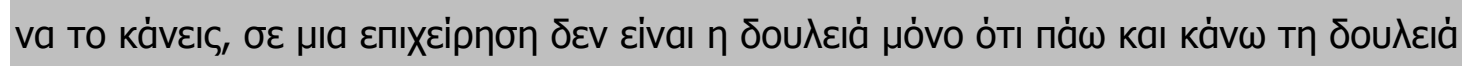

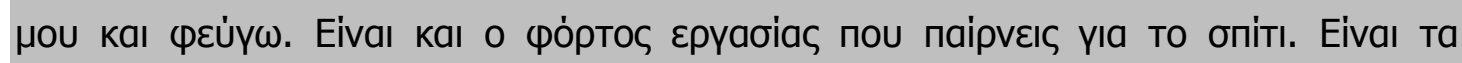

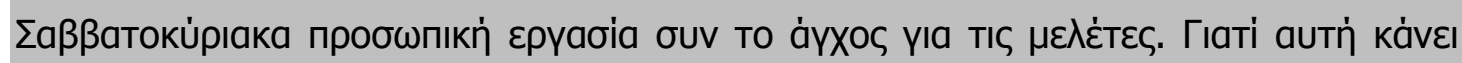

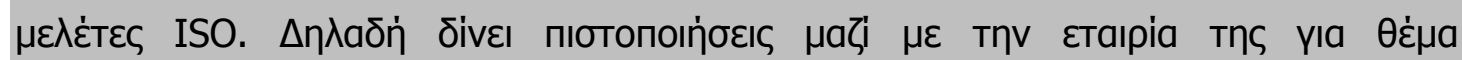

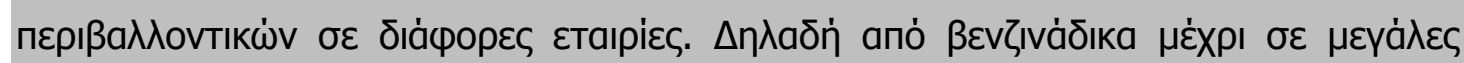

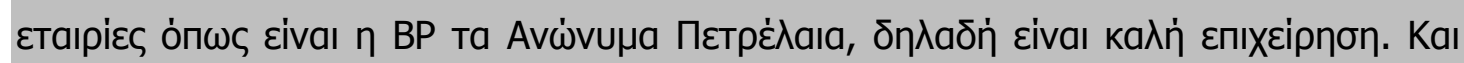

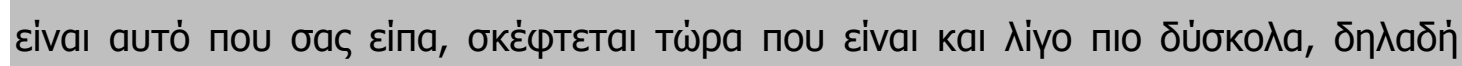

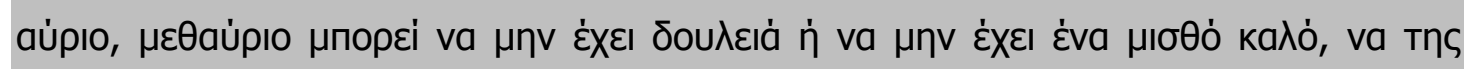

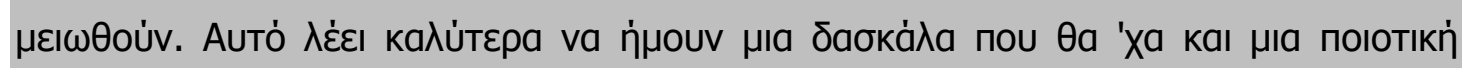

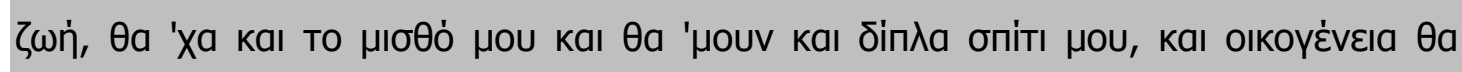

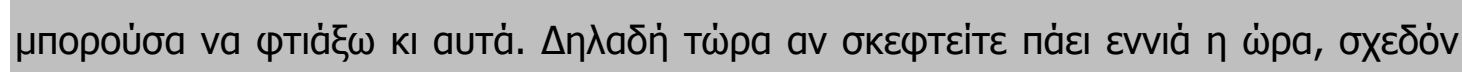

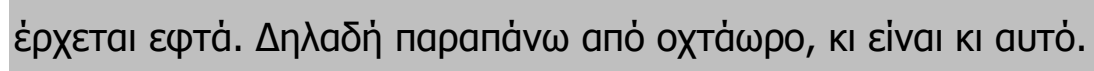

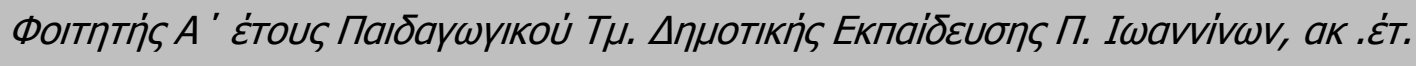
2011-12

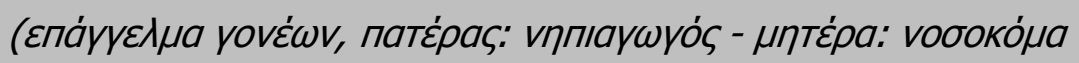

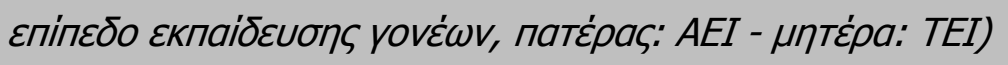

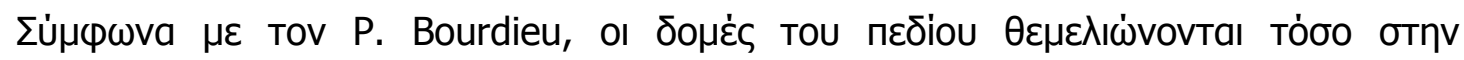

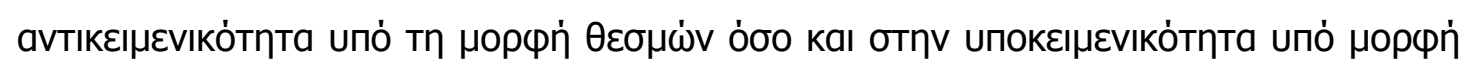




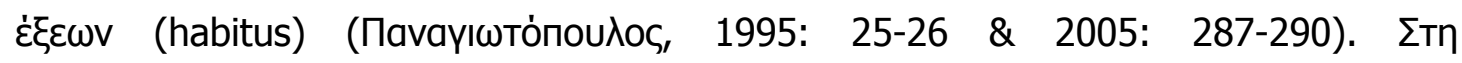

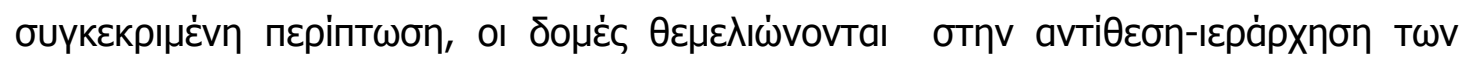

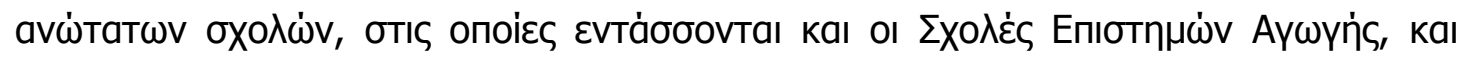

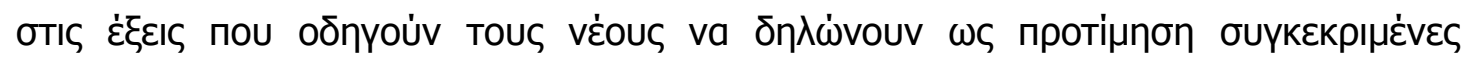

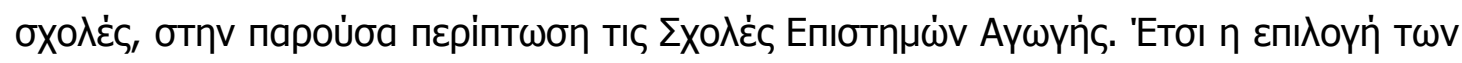

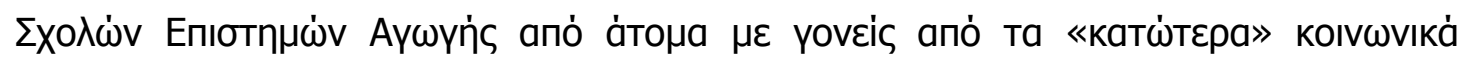

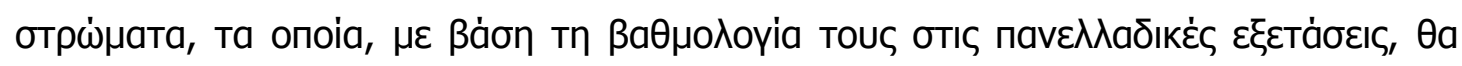

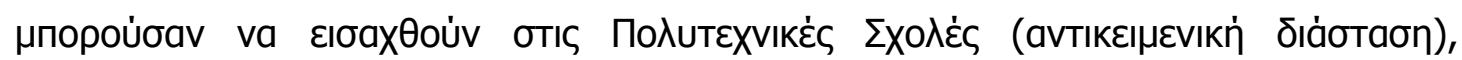

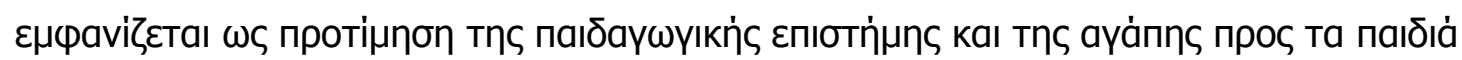

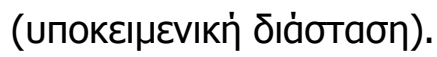

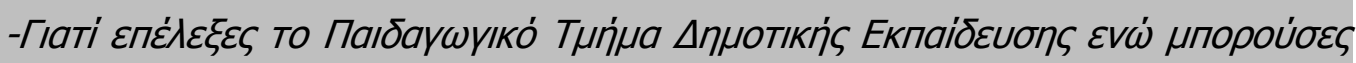

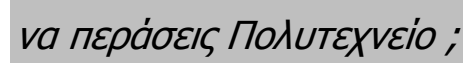

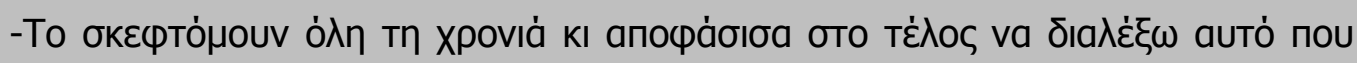

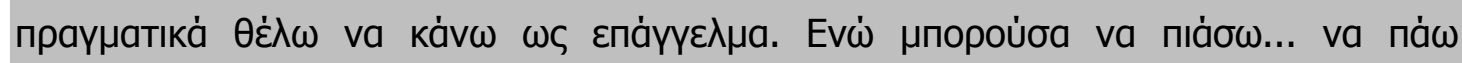

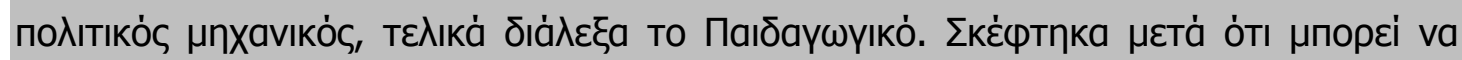

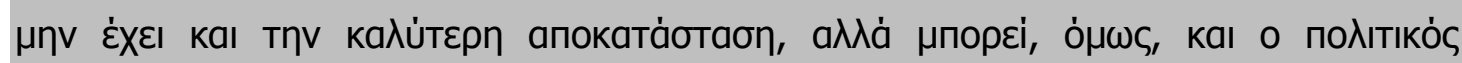

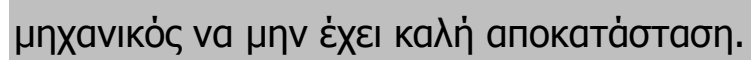

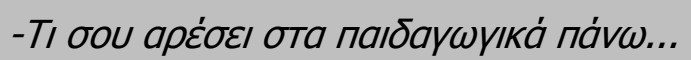

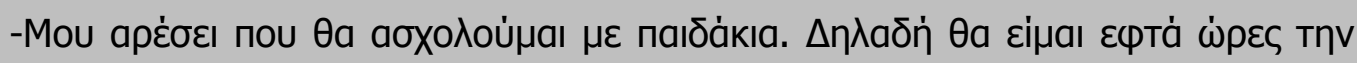

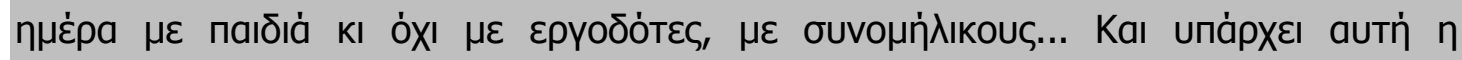
аөமótпта...

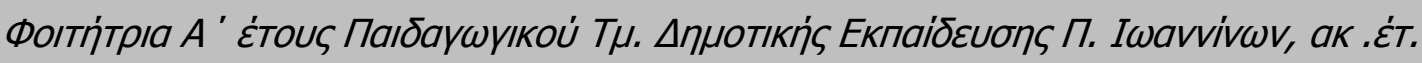
2011-12

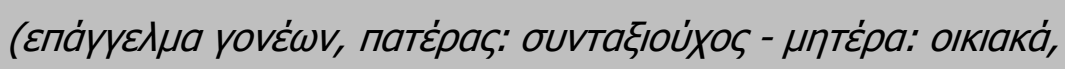

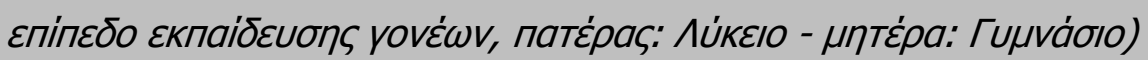

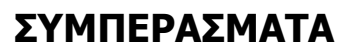

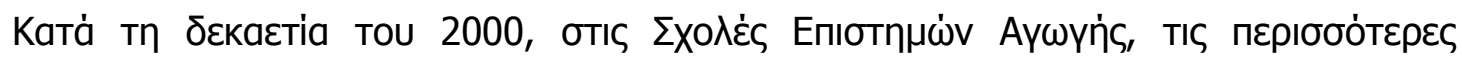

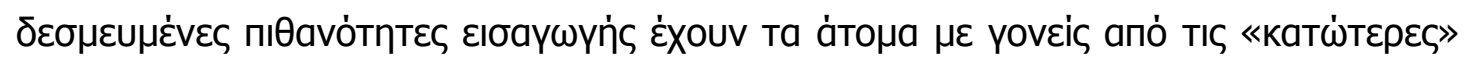

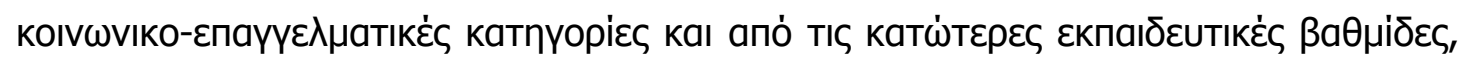

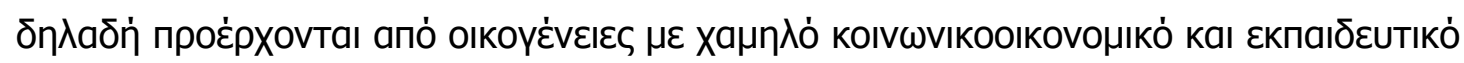




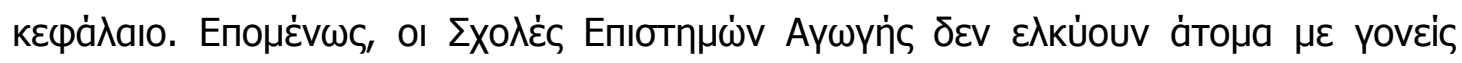

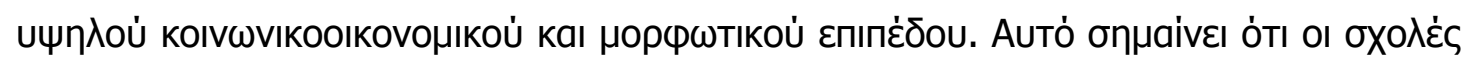

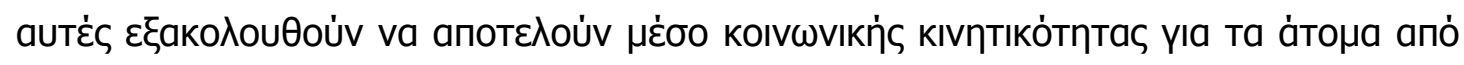

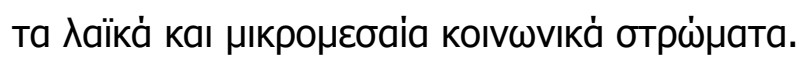

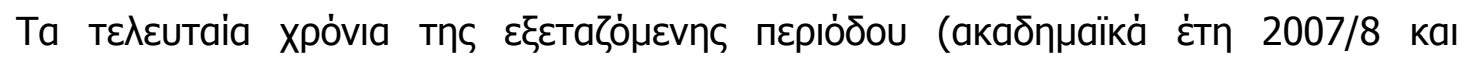

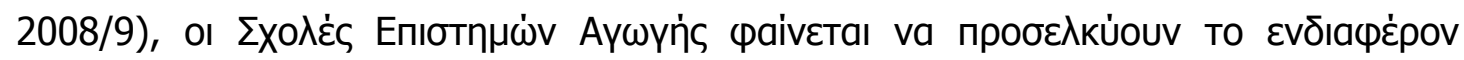

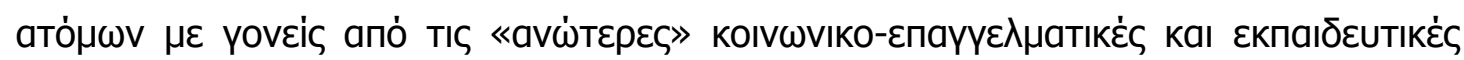

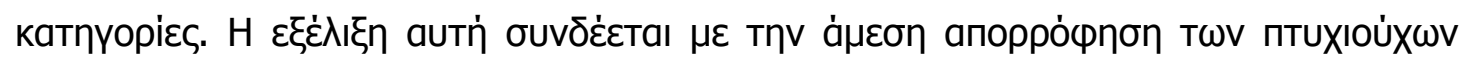

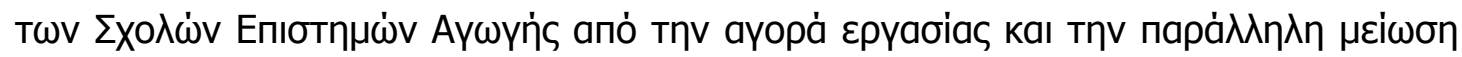

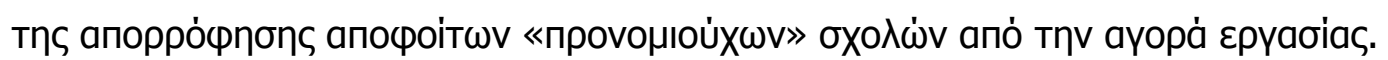

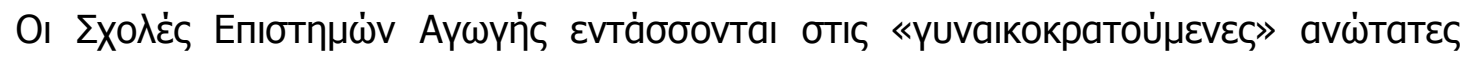

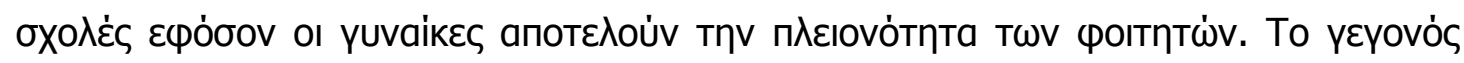

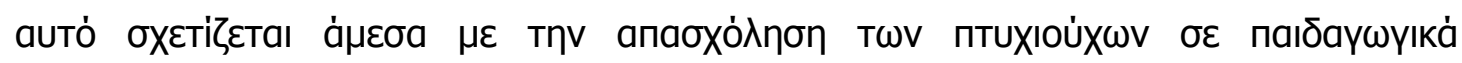

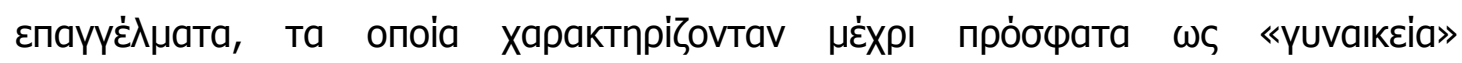

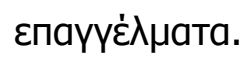

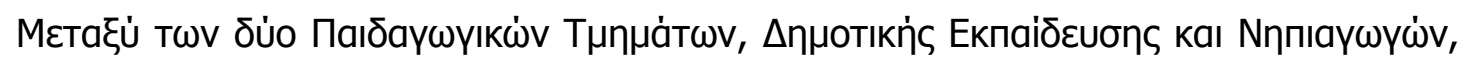

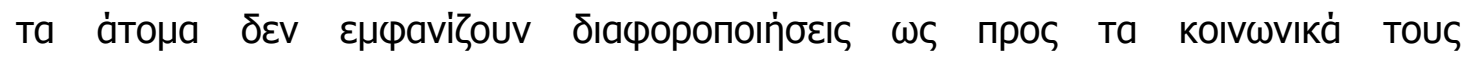

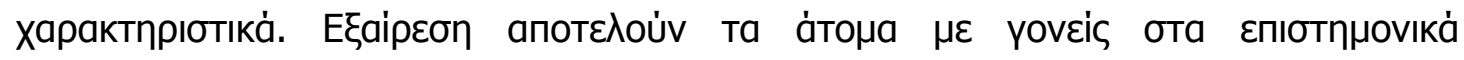

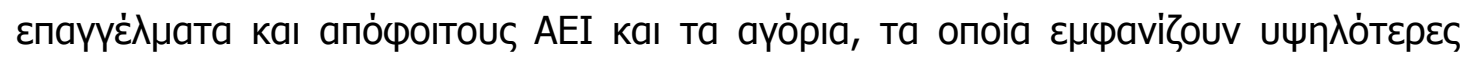

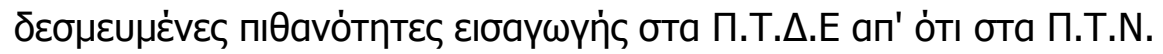

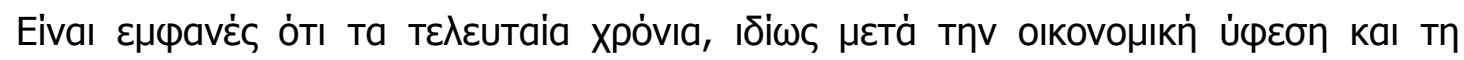

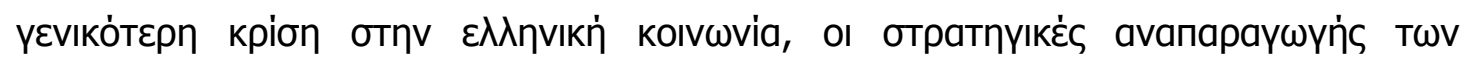

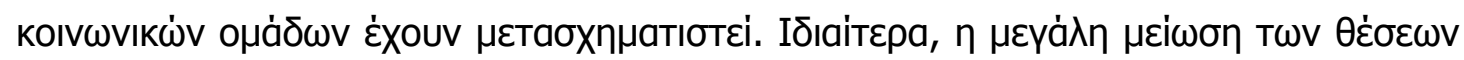

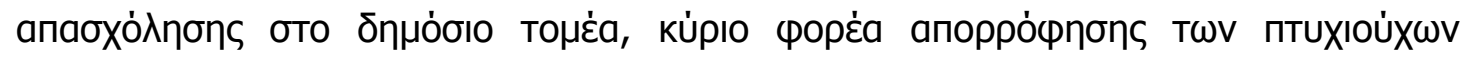

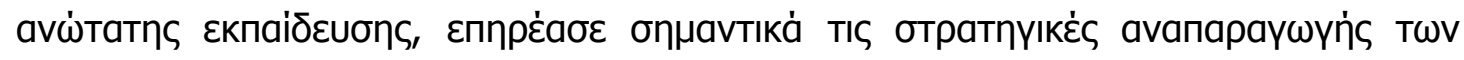

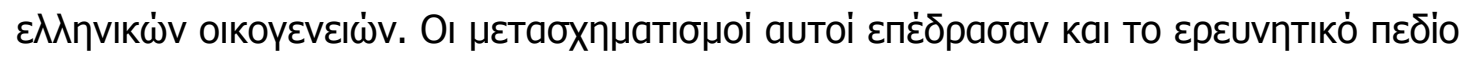

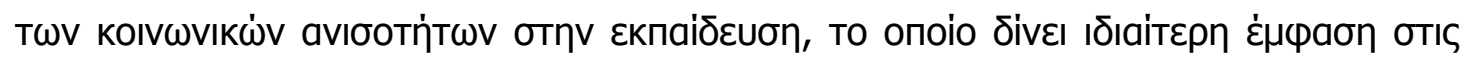

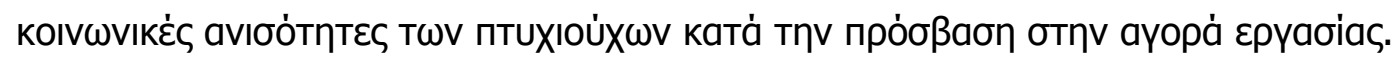




\section{ВIВАIОГРАФІА}

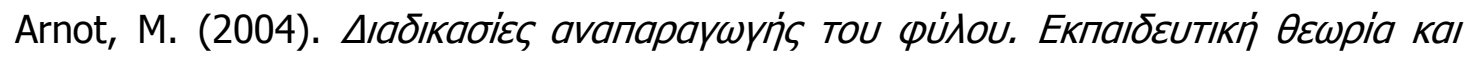

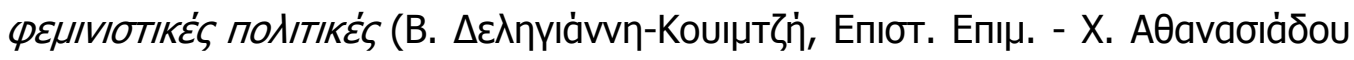

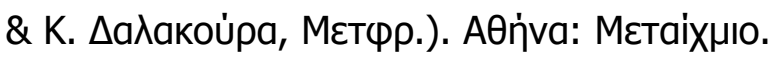

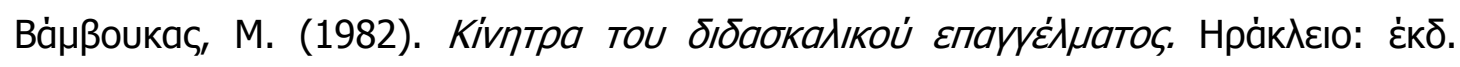
ı̇iou.

Bourdieu, P. (1989). La Noblesse d'État. Paris: Minuit.

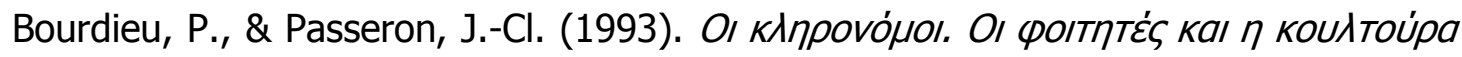

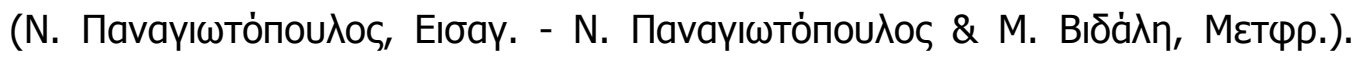

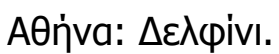

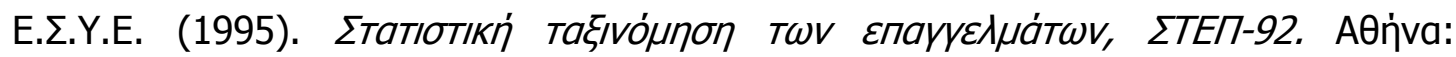
E.L.Y.E.

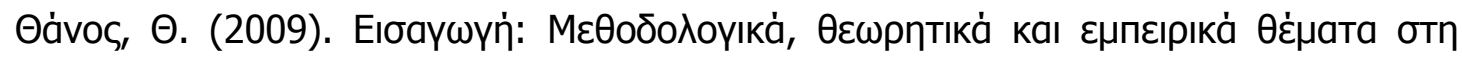

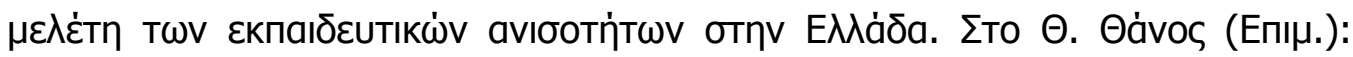

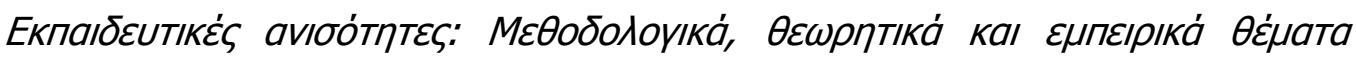

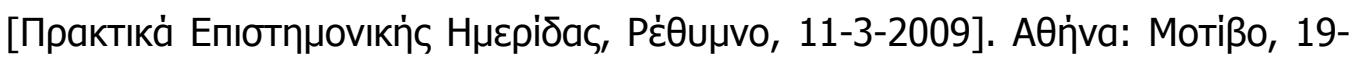
32.

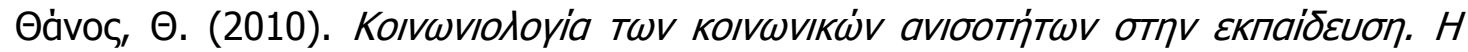

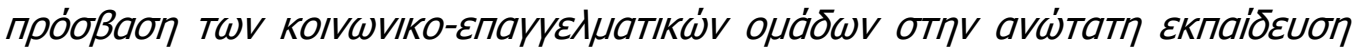

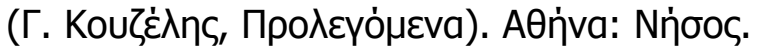

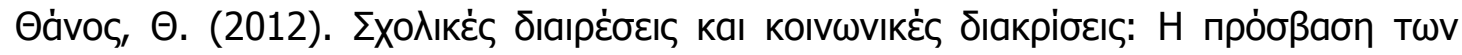

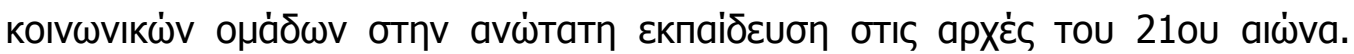

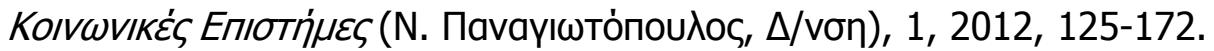

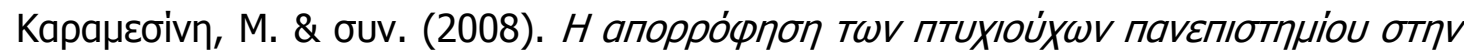

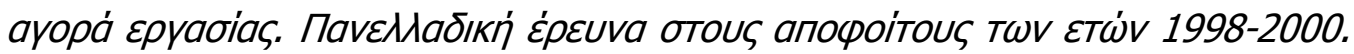

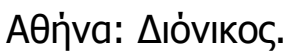

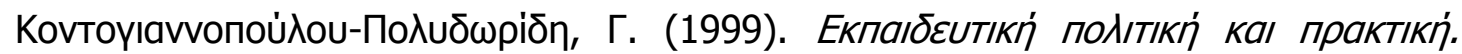

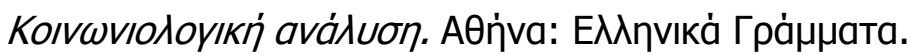

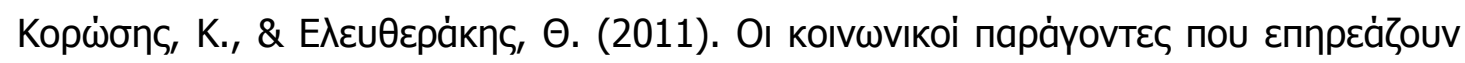

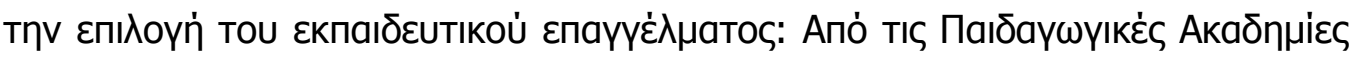

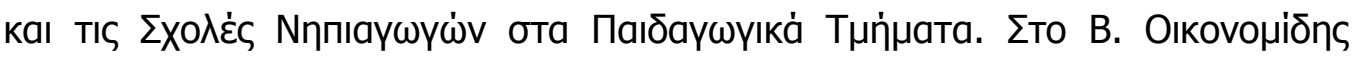

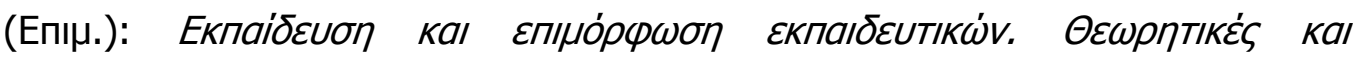

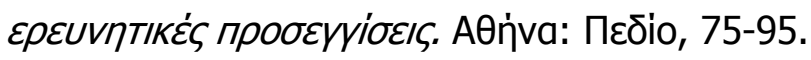

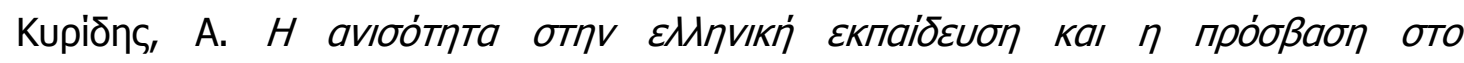

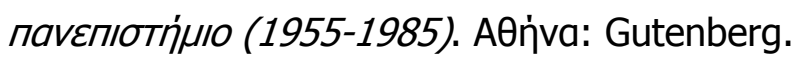




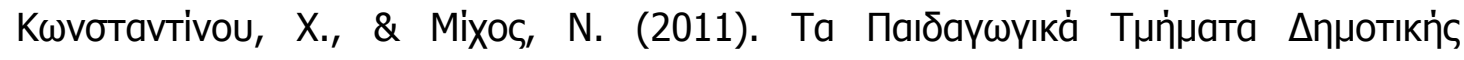

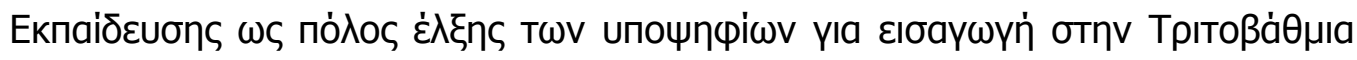

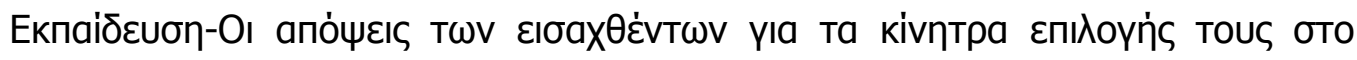

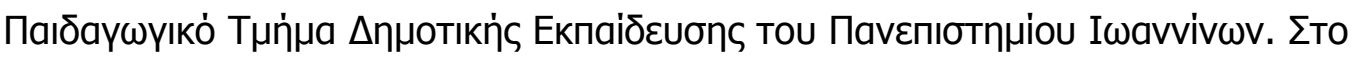

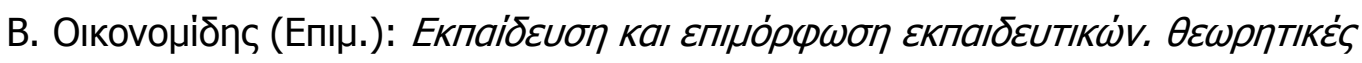

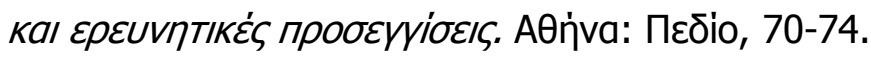

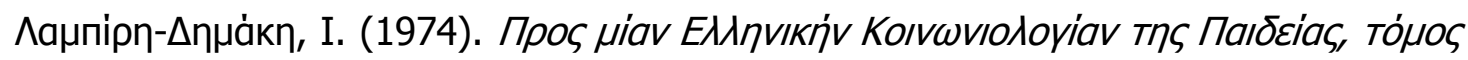

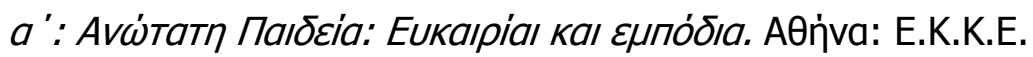

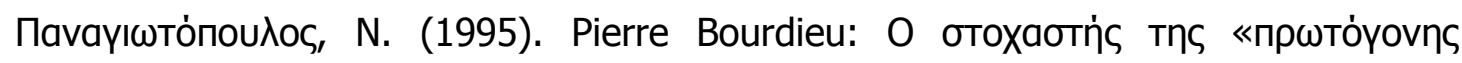

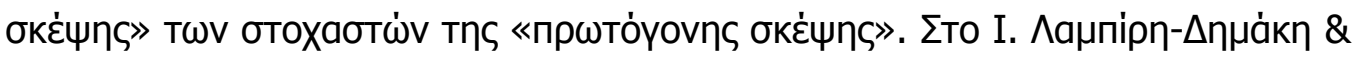

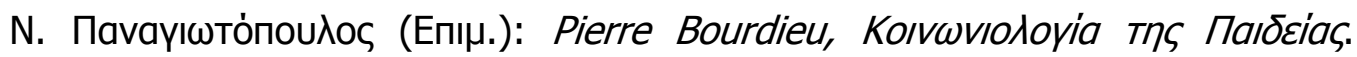

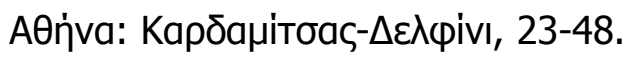

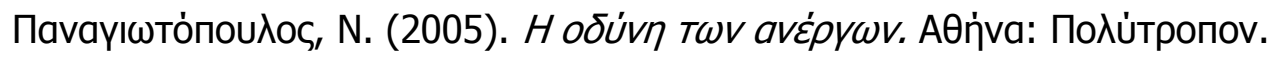

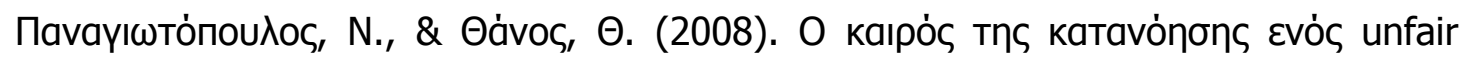

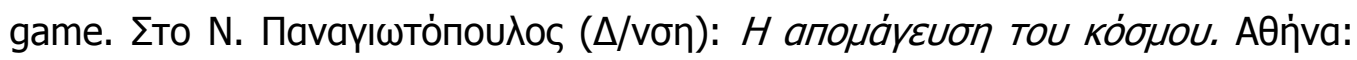
ЕККЕ-Поли́тропоV, 37-72.

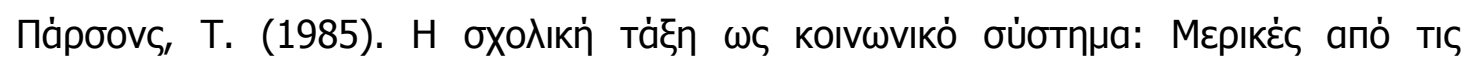

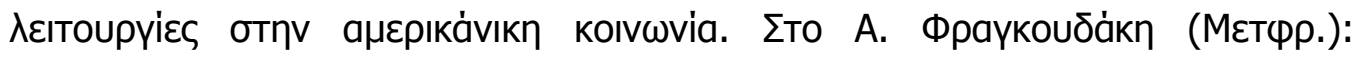

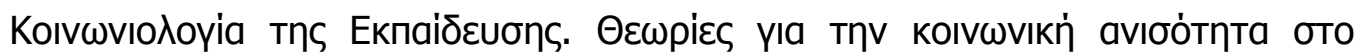

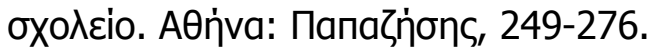

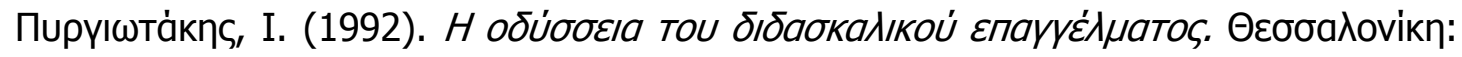
Афоi Kupıакіס̄ं.

Reay, D. (1998). 'Always knowing' and never being sure: Familial and institutional habituses and higher education choice. Journal of Education Policy, 4, 519-529.

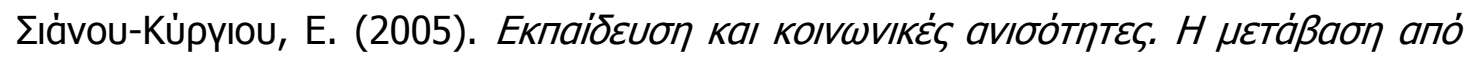

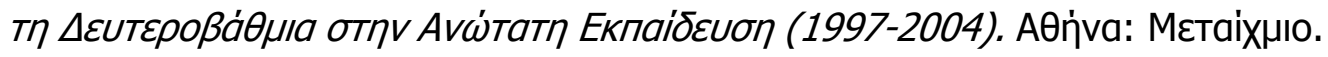

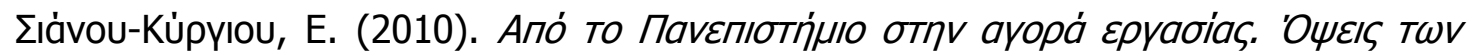

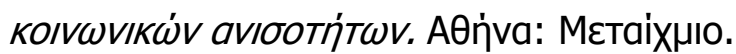

Sianou-Kyrgiou, E., \& Tsiplakides, I. (2011). Similar performance, but different choices: social class and higher education choice in Greece, Studies in Higher Education, 36(1), 89-102.

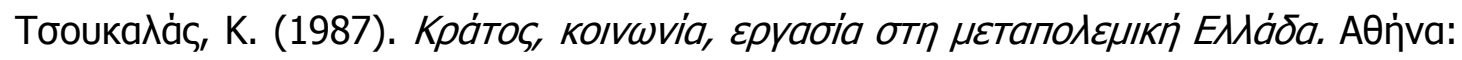
$\Theta \varepsilon \mu \dot{\lambda} \lambda ı$ ○.

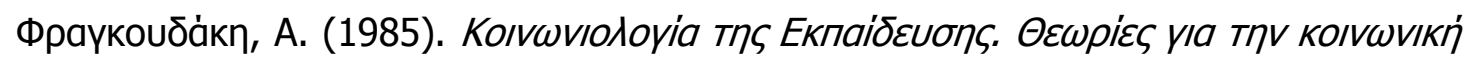

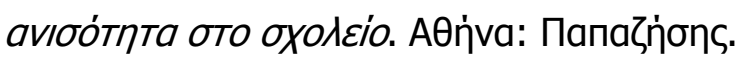

